\title{
BIOECOLOGIA E DETERMINAÇÃO DO NÍVEL DE \\ CONTROLE DE Selenaspidus articulatus (MORGAN, 1889) \\ (HEMIPTERA: DIASPIDIDAE) EM CITROS
}

\author{
ROSMARINA MARÍN LOAYZA \\ Biólogo
}

Orientador: Prof. Dr. JOSÉ ROBERTO POSTALI PARRA

Tese apresentada à Escola Superior de Agricultura "Luiz de Queiroz", Universidade de São Paulo, para obtenção do título de Doutor em Ciências, Área de Concentração: Entomologia.

P I R A C I C A B A

Estado de São Paulo - Brasil

Março - 1999 
Dados Internacionais de Catalogação na Publicação (CIP) DIVISÃo DE BIBLIOTECA E DOCUMENTAÇÃO - Campus "Luiz de Queiroz"/USP

\section{Marin Loayza, Rosmarina}

Bioecologia e determinaçăo do nivel de controle de Selenaspidus

articulatus (Morgan, 1889)(Hemiptera: Diaspididae) em citros / Rosmarina

Marin Loayza. - - Piracicaba, 1999.

110 p. : il.

Tese (doutorado) - Escola Superior de Agricultura Luiz de Queiroz, 1999.

Bibliografia.

1. Bioecologia 2. Cochonilha 3. Efeito da temperatura 4. Fotossintese 5. Fruta citrica 6 . Inceto nocivo 7. Umidade do ar 8. Variedade I. Titulo

CDD 634.3

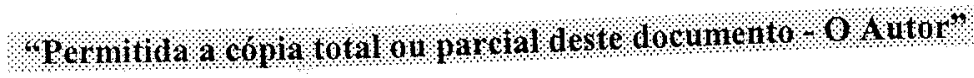


A meu pai Felipe,

pela grandiosa lição de vida,

pelo apoio, incentivo e exemplo.

Dedico

\author{
A minha mãe Rosário, \\ a meus irmãos Raul, Lida $e$ \\ José Felipe e meu sobrinho Raul, \\ pelo apoio e carinho.
}




\section{AGRADECIMENTOS}

A Deus, por ter me dado saúde e paz durante a realização deste curso.

Ao Professor Dr. José Roberto Postali Parra, pela valiosa orientação, apoio e exemplo de dedicação profissional.

À Escola Superior de Agricultura "Luiz de Queiroz", pela acolhida e apoio.

À Universidade Nacional Agraria "La Molina", Lima-Peru, pela liberação para realizar o curso de pós-graduação.

Ao CNPq - PEC-PG, acordo cultural Brasil/Peru, pela concessão de bolsa de estudo durante o curso.

Aos professores: José Djair Vendramim, Sérgio Batista Alves, Gilberto Casadei de Baptista, Octávio Nakano, Sinval Silveira Neto, Luiz Carlos Marchini, Celso Omoto, João Roberto Spotti Lopes, Evaldo F. Vilela, Gilberto José de Moraes, Luiz Carlos C.B. Ferraz, Tomamassa Matuo, Júlio Marcos Melges Walder, Francisco de Assis Alves Mourão Filho, pelos ensinamentos recebidos.

Ao professor Evôneo Berti Filho pela confecção do "summary" e amizade.

Ao professor Roberto Antônio Zucchi pela correção da morfologia do inseto.

À professora Líliam Amorin, Sílvia, Cláudia e especialmente a Renato Bassanezi pelo apoio na área da fitopatologia.

Aos funcionários do Departamento de Entomologia, Fitopatologia e Zoologia Agrícola da ESALQ/USP Neide, Cibele, Regina, Edilene, Solange, Carlinhos, Tutu e especialmente a Ana Gabriela pela atenção e cordialidade durante todo o curso.

Ao pessoal da microscopia eletrônica, Elliot W. Kitajima, Breno Leite, Silvania Machado e Fábio, pelos valiosos ensinamentos.

Às bibliotecárias, Kátia, Beatriz, Eliana e Fátima. 
Ao amigo Alexandre de Sene Pinto pela inestimável colaboração na editoração final deste trabalho.

A Marilene Fancelli pela sua ajuda e paciência com o idioma português.

Ao biólogo Heraldo Negri pelo auxílio na parte fotográfica.

Aos amigos Crébio, Maurício, Carlos Rossi, Rhainer, Patrícia Milano, Sílvia, Marconi e Jorge pelos auxilios na tese.

À Maria Teresa, Selva, Sônia Torrecillas, Ariane, Olzeno e Manuel, pelo constante apoio durante o curso e amizade.

Aos colegas do CPG em Entomologia Denize, Aninha, Laila, Sônia Micheletti, Cidoca, Terezinha, Carlos Alfredo, Elton, Marcos Tamai, Jairo, Marcos Botton, Geraldo, Charles, Rosângela, Marina, Miriam Paron, Reginaldo Barreto, Varguitas, Bety, Deoclécio, Luzinério, Eduardo, Imeuda, Odinete, Américo, Miguel e Pedro, pela amizade. 


\section{SUMÁRIO}

Página

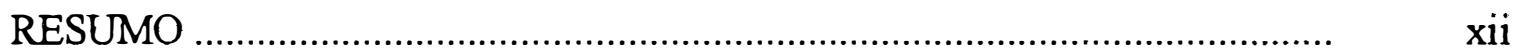

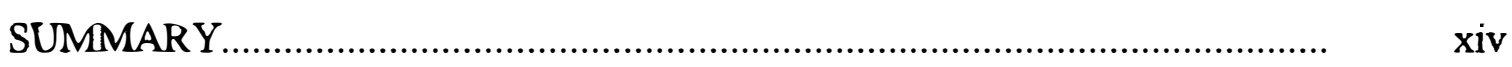

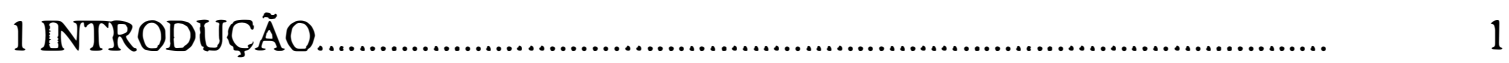

2 REVISÃO DE LITERATURA …………………..................................

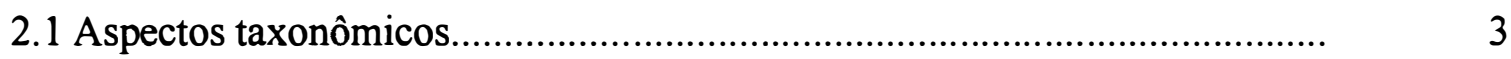

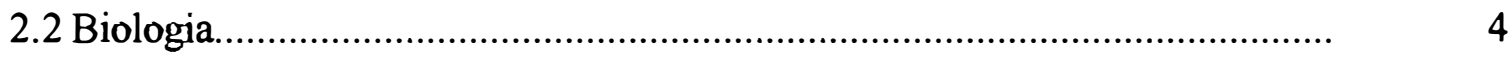

2.3 Distribuição geográfica e importância econômica........................................... 5

2.4 Plantas hospedeiras.............................................................................

2.5 Aspectos ecológicos e época de ocorrência de S. articulatus......................... 9

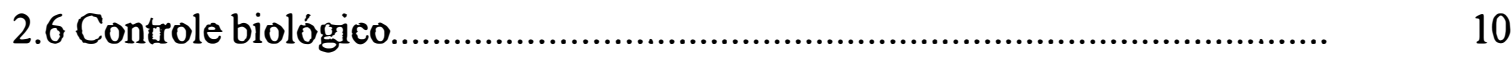

2.7 Relação entre infestação de plantas por pragas e doenças e variáveis

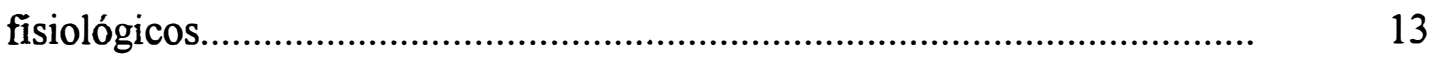

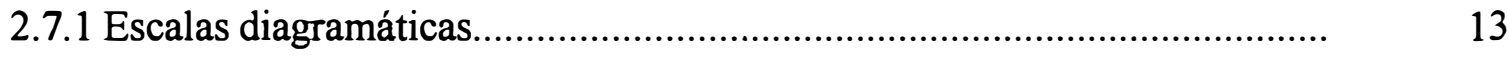

2.7.2 Exemplos de relações entre presença de patógenos e fotossíntese.............. 13

3 MATERIAL E MÉTODOS....................................................................... 15

3.1 Biologia em diferentes temperaturas, exigências térmicas e tabela de vida de fertilidade de S. articulatus................................................................ 15

3.1.1 Biologia em diferentes temperaturas...................................................... 15

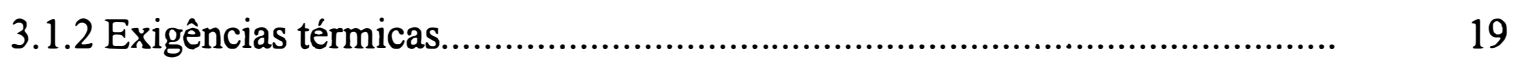

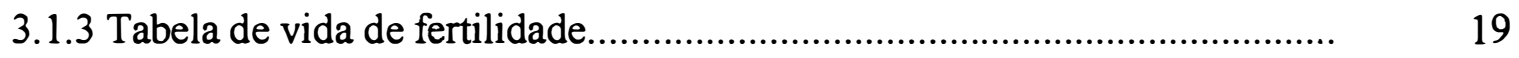

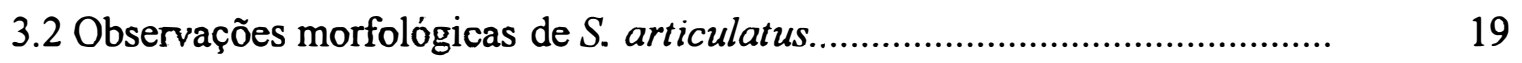

3.3 Biologia de $S$. articulatus em quatro umidades relativas do ar....................... 20

3.4 Número de gerações de S. articulatus em 5 regiões do Estado de São Paulo $\quad 20$

$\begin{array}{ll}3.5 \text { Biologia comparada de } S \text {. articulatus no hospedeiro natural e alternativo.... } & 21\end{array}$

3.6 Efeito da idade da folha de C. limonia na fixação de S. articulatus.............. 21 
Página

3.7 Determinação do nível de controle de $S$. articulatus com base na redução de parâmetros fisiológicos.

3.7.1 Confecção de uma escala diagramática................................................ 23

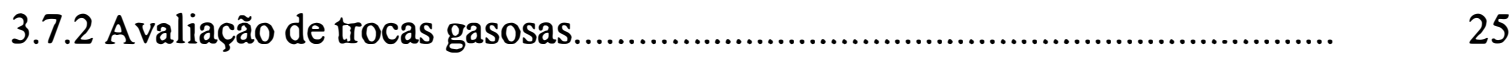

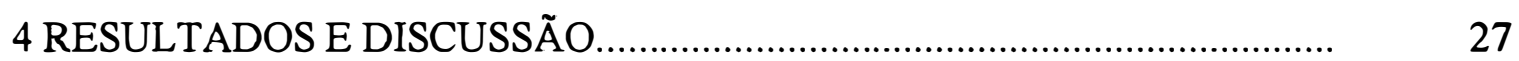

4.1 Ciclo de desenvolvimento e comportamento de Selenaspidus articulatus

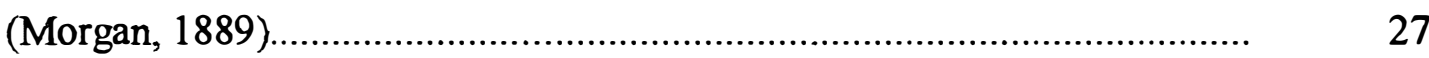

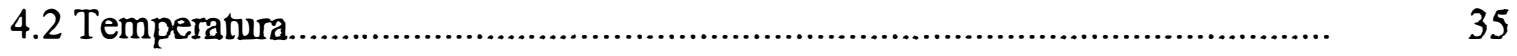

4.2.1 Influência da temperatura nas fases de desenvolvimento........................ 35

4.2.1.1 Fases imaturas.......................................................................... $\quad 35$

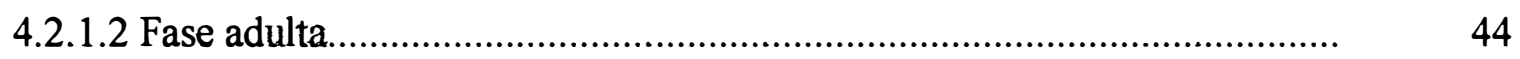

4.2.2 Determinação das exigências térmicas e número anual de gerações de $S$. articulatus.

4.2.3 Tabela de vida de fertilidade....................................................... 54

4.3 Observações morfológicas.............................................................. $\quad 58$

4.4 Efeito da umidade relativa do ar na biologia de $S$. articulatus...................... 68

4.5 Biologia comparada de $S$. articulatus em variedades de Citrus e em Citrullus silvestris.

4.6 Efeito da idade da folha na fixação de S. articulatus......

4.7 Determinação do nível de controle de $S$. articulatus com base na redução

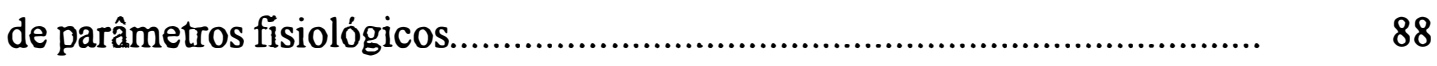

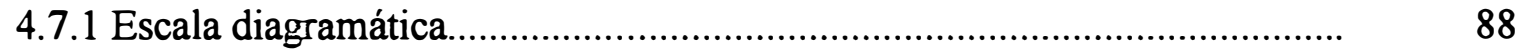

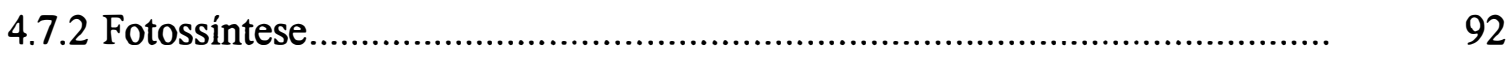

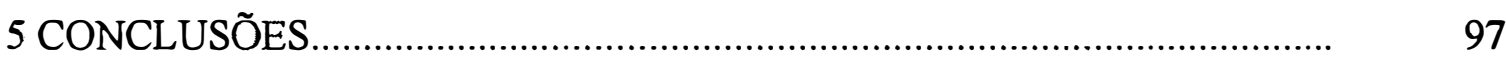

REFERÊNCIAS BIBLIOGRÁFICAS .............................................. 99 


\section{LISTA DE FIGURAS}

Figura $n^{\circ}$.

Página

1. Bandejas plásticas contendo os tubetes com mudas de C. limonia infestadas com $S$. articulatus (A) e método de infestação de mudas com ninfas da cochonilha através de estiletes finos (B)

2. Marcação, com caneta de retroprojetor, dos indivíduos de $S$. articulatus observados nos ensaios de biologia, em folhas de $C$. limonia infestadas

3. Mapa do Estado de São Paulo com cidades representativas das principais regiões citrícolas

4. Frutos de Citrus (A) e C. silvestris (B) infestados com S. articulatus, utilizados nos ensaios

5. Escala diagramática utilizada para diferenciação dos níveis de infestação de $S$. articulatus em folhas de Citrus, com níveis variando de 0,5 a $35 \%$

6. Equipamento, modelo LI-6400 Portable Photosynthesis System (LiCor®), utilizado para medição das variáveis fisiológicas

7. Ciclo de desenvolvimento de fêmeas $\left(_{1}\right)$ e machos $\left({ }_{2}\right)$ e carapaças (') de $S$. articulatus. A - ninfa 1 móvel; B - ninfa 1 séssil; C - ninfa 2; D - "pré-pupa" (c - exúvia); E - "pupa" e; F - adulto (a - jovem; b maduro sexualmente)

8. Formato da carapaça dorsal (vista dorsal - A; vista ventral - C; abertura na carapaça - D) da fềmea e do macho (B) de S. articulatus, e bandas circulares das mesmas, representando os períodos de crescimento das ninfas de primeiro (1a - carapaça branca; lb carapaça amarela) e segundo (2) ínstares e do adulto (3). E - secreção filamentosa para fixação na folha

9. Viabilidade (\%) do ciclo total (fase móvel - adulto) de fêmeas (A) e machos (B) de $S$. articulatus sobre mudas de $C$. limonia em diferentes temperaturas. UR: $60 \pm 10 \%$; fotofase: 14 horas. Barras seguidas das mesmas letras não diferem significativamente pelo teste de Ducan a $5 \%$

10. Tratamentos utilizados nos ensaios de diferentes temperaturas, destacando-se a maior desfolha naqueles à 25 e $28^{\circ} \mathrm{C}$

11. Ritmo de oviposição de $S$. articulatus em folhas de $C$. limonia em diferentes temperaturas. UR: $60 \pm 10 \%$; fotofase: 14 horas 
Figura $\mathrm{n}^{\circ}$.

Página

12. Curvas de sobrevivência de Weibull para fêmeas de $S$. articulatus em folhas de C. limonia em diferentes temperaturas. UR: $60 \pm 10 \%$; fotofase: 14 horas.

13. Curvas de sobrevivência de Weibull para machos de S. articulatus em folhas de C. limonia em diferentes temperaturas. UR: $60 \pm 10 \%$; fotofase: 14 horas.

14. Curvas de velocidade dos diferentes ínstares de fêmeas e machos de $S$. articulatus em folhas de C. limonia. UR: $60 \pm 10 \%$; fotofase: 14 horas..

15. S. articulatus A. Antena da ninfa móvel (115X). B. Último segmento antenal (155X). C. Parte ventral da ninfa móvel (70X). D. Tarso posterior da ninfa móvel (210X).

16. S. articulatus. A. Pigídio da ninfa móvel (150X). B. Espiráculos respiratórios da fêmea adulta (125X). C. Pigídio da ninfa II (fêmea) (202X). D. Pigídio da ninfa II (macho) (60X).

17. S. articulatus. A. Prossoma e possoma, vista ventral (8X). B. Protuberância da margem lateral do prossoma (20X). C. Aparelho bucal da fêmea adulta (20X). D. Tubérculo antenal da fêmea adulta (300X).

18. S. articulatus. Pigídio da fèmea adulta apresentando detalhes da vulva (25X). B. Margem posterior do pigídio da fêmea adulta (67X). C. Pigídio em vista ventral apresentando detalhes dos lóbulos e ductos glandulares da fêmea adulta (82X). D. Detalhe das placas localizadas na margem lateral do pigídio da fêmea adulta (110X).

19. S. articulatus. A. Pigídio da fêmea adulta em vista ventral apresentando detalhes dos poros perivulvares (46X). B. Filamentos glandulares da margem lateral do pigídio (200X). C. Carapaça da cochonilha (5X). D. Filamentos da carapaça (290X)

20. S. articulatus. A. Antena da prépupa (macho) (30X). B. Pupa (macho) em vista dorsal (12X). C. Pigídio prépupa (macho) (50X). D. Pigideo da pupa (macho) (50X)...

21. S. articulatus. A. Antena do macho adulto (25X). B. Segmento antenal (macho) apresentando as cerdas sensoriais. C. Último segmento do pigídeo do macho adulto (50X). D. Edeago do macho adulto (50X).......

22. Viabilidade (\%) do ciclo total (fase móvel - adulto) de fêmeas (A) e machos (B) de $S$. articulatus sobre mudas de $C$. limonia em diferentes umidades relativas do ar. Temperatura: $25 \pm 2^{\circ} \mathrm{C}$; fotofase: 14 horas. Barras seguidas das mesmas letras não diferem significativamente pelo teste de Ducan a 5\%. 
Figura $n^{\circ}$.

Página

23. Ritmo de oviposição de $S$. articulatus em folhas de $C$. limonia em diferentes umidades relativas do ar. Temperatura: $25 \pm 2^{\circ} \mathrm{C}$; fotofase: 14 horas.

24. Curvas de sobrevivência de Weibull para fêmeas de $S$. articulatus em mudas de $C$. limonia em diferentes umidades relativas do ar. Temperatura: $25 \pm 2^{\circ} \mathrm{C}$; fotofase: 14 horas..

25. Curvas de sobrevivência de Weibull para machos de $S$. articulatus em mudas de $C$. limonia em diferentes umidades relativas do ar. Temperatura: $25 \pm 2^{\circ} \mathrm{C}$; fotofase: 14 horas..

26. Viabilidade (\%) do ciclo total (fase móvel - adulto) de fêmeas (A) e machos (B) de $S$. articulatus sobre frutos de Citrus e C. silvestris. Temperatura: $25 \pm 2^{\circ} \mathrm{C}$; UR: $60 \pm 10 \%$; fotofase: 14 horas. Barras seguidas das mesmas letras não diferem significativamente pelo teste de Ducan a $5 \%$.

27. Porcentagem de fixação de $S$. articulatus em folhas de $C$. limonia, em três estágios de desenvolvimento. Temperatura: $25 \pm 2{ }^{\circ} \mathrm{C}$; UR: $60 \pm 10$ $\%$; fotofase: 14 horas.

28. Avaliação da severidade de ataque da cochonilha $S$. articulatus, na face adaxial da folha de C. limonia .

29. Avaliação da severidade de ataque da cochonilha $S$. articulatus, na face abaxial da folha de C. limonia.

30. Taxa fotossintética de folhas de C. limonia $\left(\mu \mathrm{mol} \mathrm{CO}_{2} \cdot \mathrm{m}^{-2} \cdot \mathrm{s}^{-1}\right)$ com sintomas de ataque de cochonilhas e com sintomas, e sem cochonilhas (elas foram removidas)

31. Dano em folha de C. limonia causado pela alimentação e injeção de saliva tóxica de $S$. articulatus no local da picada.

32. Efeito de $S$. articulatus na fotossíntese relativa (proporção), condutância estomática $\left(m o l \mathrm{H}_{2} \mathrm{O} \cdot \mathrm{m}^{-2} \cdot \mathrm{s}^{-1}\right.$ ) e na taxa de transpiração de folhas ( $\mathrm{mmol} \mathrm{H}_{2} \mathrm{O} \cdot \mathrm{m}^{-2} \cdot \mathrm{s}^{-1}$ ) de mudas de C. limonia

33. Efeito de níveis de severidade de ataque de $S$. articulatus nas variáveis taxa fotossintética líquida $\left(\mu \mathrm{mol} \mathrm{CO}_{2} \cdot \mathrm{m}^{-2} \cdot \mathrm{s}^{-1}\right)$, condutância estomática $\left(\mathrm{mol} \mathrm{H} \mathrm{H}_{2} \mathrm{O} \cdot \mathrm{m}^{-2} \cdot \mathrm{s}^{-1}\right)$ e taxa de transpiração $\left(\mathrm{mmol} \mathrm{H}_{2} \mathrm{O} \cdot \mathrm{m}^{-2} \cdot \mathrm{s}^{-1}\right)$. Barras seguidas de mesma letra não diferem entre si pelo teste de Duncan, ao nível de $5 \%$ de probabilidade 


\section{LISTA DE TABELAS}

Tabela $n^{\circ}$

Página

1. Comprimento e largura $(\mathrm{mm})$ das fases imaturas e adultos, de ambos os sexos, de $S$. articulatus criados em laboratório, sobre $C$. limonia em temperaturas variáveis. UR: $60 \pm 10 \%$; fotofase: 14 horas

2. Duração (dias) das fases imaturas e do ciclo total ( fase móvel adulto) de fêmeas de $S$. articulatus sobre mudas de $C$. limonia em diferentes temperaturas. UR: $60 \pm 10 \%$; fotofase: 14 horas

3. Duração (dias) das fases imaturas e do ciclo total (fase móvel - adulto) de machos de $S$. articulatus sobre mudas de $C$. limonia em diferentes temperaturas. UR: $60 \pm 10 \%$; fotofase: 14 horas.

4. Viabilidade (\%) da fase móvel (fixação) e das fases imaturas de fêmeas de $S$. articulatus sobre mudas de $C$. limonia em diferentes temperaturas. UR: $60 \pm 10 \%$; fotofase: 14 horas.

5. Viabilidade (\%) da fase móvel (fixação), das fases imaturas de machos de $S$. articulatus sobre mudas de $C$. limonia em diferentes temperaturas. UR: $60 \pm 10 \%$; fotofase: 14 horas.

6. Duração dos períodos de "pré-oviposição", "oviposição" e longevidade de fêmeas e de machos de $S$. articulatus sobre mudas de C. limonia em diferentes temperaturas. UR: $60 \pm 10 \%$; fotofase: 14 horas.

7. Fecundidade de $S$. articulatus criadas sobre mudas de $C$. limonia em diferentes temperaturas. UR: $60 \pm 10 \%$; fotofase: 14 horas.

8. Duração do ciclo de vida (fase móvel - morte do adulto) (dias) de fêmeas de $S$. articulatus sobre mudas de $C$. limonia em diferentes temperaturas. UR: $60 \pm 10 \%$; fotofase: 14 horas.

9. Relação sexual e razão sexual de $S$. articulatus em folhas de $C$. limonia em diferentes temperaturas. UR: $60 \pm 10 \%$; fotofase: 14 horas

10. Temperatura base $(\mathrm{Tb})$, constante térmica $(\mathrm{k})$ e coeficiente de determinação $\left(\mathrm{R}^{2}\right)$ de $S$. articulatus (fêmea e macho) baseando-se no desenvolvimento em $C$. limonia

11. Normas térmicas em cinco regiões citrícolas de Estado de São Paulo para machos e fêmeas de $S$. articulatus

12. Número provável de gerações de $S$. articulatus em cinco regiões citrícolas do Estado de São Paulo, com base na sua constante térmica.... 
Tabela $\mathrm{n}^{\circ}$.

Página

13. Duração média da geração $(T)$, taxa líquida de reprodução $\left(R_{0}\right)$, razão infinitesimal de aumento $\left(\mathrm{r}_{\mathrm{m}}\right)$ e razão finita de aumento $(\lambda)$ para $S$. articulatus em diferentes temperaturas. Umidade $60 \pm 10 \%$; fotofase 14 horas.

14. Duração (dias) das fases imaturas e do ciclo total (da fase móvel adulto) de fêmeas de $S$. articulatus sobre mudas de $C$. limonia em diferentes umidades relativas do ar. Temperatura: $25^{\circ} \mathrm{C}$; fotofase: 14 horas.

15. Duração (dias) das fases imaturas e do ciclo total ( fase móvel adulto) de machos de $S$. articulatus sobre mudas de $C$. limonia em diferentes umidades relativas do ar. Temperatura: $25^{\circ} \mathrm{C}$; fotofase: 14 horas.

16. Viabilidade (\%) da fase móvel (fixação), das fases imaturas de fềmeas de $S$. articulatus sobre mudas de $C$. limonia em diferentes umidades relativas do ar. Temperatura: $25 \pm 2{ }^{\circ} \mathrm{C}$; fotofase: 14 horas.

17. Viabilidade (\%) da fase móvel (fixação), das fases imaturas de machos de $S$. articulatus sobre mudas de $C$. limonia em diferentes umidades relativas do ar. Temperatura: $25 \pm 2{ }^{\circ} \mathrm{C}$; fotofase: 14 horas.

18. Duração dos períodos de "pré-oviposição", "oviposição" e longevidade de fêmeas e de machos de $S$. articulatus sobre mudas de C. limonia em diferentes umidades relativas do ar. Temperatura: $25 \pm 2{ }^{\circ} \mathrm{C}$; fotofase: 14 horas

19. Relação sexual e razão sexual de $S$. articulatus em folhas de $C$. limonia em diferentes umidades. Temperatura: $25 \pm 2{ }^{\circ} \mathrm{C}$; fotofase: 14 horas.

20. Fecundidade de $S$. articulatus criadas sobre mudas de $C$. limonia em diferentes umidades relativas do ar. Temperatura: $25 \pm 2{ }^{\circ} \mathrm{C}$; fotofase: 14 horas.

21. Duração do ciclo de vida (fase móvel - morte do adulto) (dias) de fêmeas de $S$. articulatus sobre mudas de $C$. limonia em diferentes umidades relativas do ar. Temperatura: $25^{\circ} \mathrm{C}$; fotofase: 14 horas

22. Duração média da geração $(T)$, taxa líquida de reprodução $\left(R_{0}\right)$, razão infinitesinmal de aumento $\left(\mathrm{r}_{\mathrm{m}}\right)$ e razão finita de aumento $(\lambda)$ para $S$. articulatus em diferentes umidades. Temperatura: $25^{\circ} \mathrm{C}$; fotofase 14 horas 
Tabela $\mathrm{n}^{\circ}$.

Página

23. Duração (dias) das fases imaturas e do ciclo total (fase móvel - adulto) de fêmeas de $S$. articulatus em 4 variedades de laranja e C. silvestris. Temperatura: $25 \pm 2^{\circ} \mathrm{C}$; UR: $60 \pm 10 \%$; fotofase: 14 horas .

24. Duração (dias) das fases imaturas e do ciclo total (fase móvel - adulto) de machos de $S$. articulatus em 4 variedades de laranja e $C$. silvestris. Temperatura: $25 \pm 2^{\circ} \mathrm{C}$; UR: $60 \pm 10 \%$; fotofase: 14 horas .

25. Viabilidade (\%) da fase móvel (fixação), das fases imaturas de fêmeas de $S$. articulatus em 4 variedades de laranja e $C$. silvestris. Temperatura: $25 \pm 2^{\circ} \mathrm{C}$; UR: $60 \pm 10 \%$; fotofase: 14 horas .

26. Viabilidade (\%) da fase móvel (fixação), das fases imaturas de machos de $S$. articulatus em 4 variedades de laranja e C. silvestris. Temperatura: $25 \pm 2^{\circ} \mathrm{C}$; UR: $60 \pm 10 \%$; fotofase: 14 horas

27. Relação sexual e razão sexual de $S$. articulatus em 4 variedades de laranja e $C$. silvestris. Temperatura: $25 \pm 2^{\circ} \mathrm{C}$; UR: $60 \pm 10 \%$; fotofase: 14 horas.

28. Número médio de $S$. articulatus em folhas de $C$. limonia, em três estágios de desenvolvimento. Temperatura: $25 \pm 2^{\circ} \mathrm{C}$; UR: $60 \pm 10 \%$; fotofase: 14 horas.

29. Valores obtidos da regressão linear entre a severidade real de $S$. articulatus e a severidade observada na face adaxial

30. Valores obtidos da regressão linear entre a severidade real de $S$. articulatus e a severidade observada na face abaxial 


\title{
BIOECOLOGIA E DETERMINAÇÃO DO NÍVEL DE CONTROLE DE Selenaspidus articulatus (MORGAN, 1889) (HEMIPTERA: DIASPIDIDAE) EM CITROS
}

\author{
Autor: ROSMARINA MARÍN LOAYZA \\ Orientador: Dr. JOSÉ ROBERTO POSTALI PARRA
}

RESUMO

O objetivo da pesquisa foi avaliar o desenvolvimento de Selenaspidus articulatus (Morgan, 1889) em diferentes temperaturas e umidades relativas do ar, para definir áreas, no Estado de São Paulo, nas quais esta praga tenha maior possibilidade de aumentar o seu nível populacional, e, conseqüentemente causar maiores prejuízos. Paralelamente, foi conduzido um estudo correlacionando a área foliar danificada pela praga e a atividade fotossintética, para definir o nível de controle da praga. Concluiu-se que a faixa de desenvolvimento de $S$. articulatus situou-se entre 18 e $28{ }^{\circ} \mathrm{C}$, e, que não ocorreu desenvolvimento a $32{ }^{\circ} \mathrm{C}$. A maior fecundidade desta praga ocorreu entre $25 \mathrm{e}$ $28^{\circ} \mathrm{C}$, sendo que o ritmo de postura, nas melhores condições, foi crescente até os 60 dias. As maiores longevidades de fềmeas foram obtidas a $18^{\circ} \mathrm{C}$, sendo semelhantes nas demais condições térmicas. Por outro lado, os machos viveram poucas horas, com maior longevidade a 25 e $28{ }^{\circ} \mathrm{C}$. Nestas duas temperaturas, através de tabela de vida de fertilidade, ocorreram as maiores taxas líquidas de reprodução $\left(R_{0}\right)$ e razão finita de aumento $(\lambda)$. Em função das exigências térmicas, $S$. articulatus pode apresentar de 6,4 a 9,8 gerações anuais nas principais áreas citrícolas de São Paulo (Barretos, Araraquara, Limeira, São José do Rio Preto e Bebedouro). A maior fecundidade de $S$. articulatus ocorreu na faixa de UR de $50-70 \%$. A umidade relativa mais adequada para $S$. articulatus é a de $70 \%$, pois nesta condição ocorreu maior fecundidade e obteve-se a maior taxa líquida de reprodução $\left(R_{0}\right)$ e razão finita de aumento $(\lambda)$. Umidades relativas 
mais baixas dificultaram a fixação de ninfas móveis de $S$. articulatus, sendo que no $1^{\circ}$ instar é crítico, pois foi onde ocorreu maior mortalidade, independente da temperatura ou da UR. Na fase imatura, as fềmeas de $S$. articulatus têm 2 ínstares (uma fase móvel e um ínstar fixo) e o macho 4 estágios ( uma fase móvel e três ínstares fixos). $S$. articulatus apresentou preferência por folhas novas de Citrus limonia para fixação. A variedade 'Hamlin' foi a preferida pela cochonilha pardinha, quando comparada com Pera, Natal e Valência e com a espécie Citrullus silvestris, o qual é considerado hospedeiro adequado para criação de $S$. articulatus, por proporcionar boa viabilidade do inseto e pelo fato do seu fruto apresentar alta durabilidade. Após a fixação, os danos causados pela cochonilha são irreversíveis. O nível de controle de $S$. articulatus foi de 30 cochonilhas por folha, o correspondente a $7 \%$ de severidade, com base na taxa fotossintética, condutância estomática e taxa de transpiração. 


\title{
BIOECOLOGY AND ECONOMIC THRESHOLD LEVEL DETERMINATION OF Selenaspidus articulatus (MORGAN, 1889) (HEMIPTERA: DIASPIDIDAE) IN CITRUS CROP
}

\author{
Author: ROSMARINA MARÍN LOAYZA \\ Adviser: Dr. JOSÉ ROBERTO POSTALI PARRA
}

\section{SUMMARY}

This research was carried out in order to evaluate the development of Selenaspidus articulatus (Morgan, 1889) (Hemiptera: Diaspididae) at different temperatures and relative humidities to determine areas of the State of São Paulo in wich this insect will have better conditions to increase the population level and, consequently, cause higher damages. The level of control of this pest was determined by correlating photosynthesis with damaged leaf area.It was observed that $S$. articulatus develops between 18 and $28^{\circ} \mathrm{C}$, but not at $32^{\circ} \mathrm{C}$. The highest fecundity occurred between 25 and $28^{\circ} \mathrm{C}$ and egg laying increased up to 60 days. The highest longevities of the females were obtained at $18^{\circ} \mathrm{C}$. On the other hand, the males lived only a few hours, with highest longevity at 25 and $28^{\circ} \mathrm{C}$. Concerning the life table of fertility, the highest net reproductive rate $\left(R_{0}\right)$ and finite increase rate $(\lambda)$ were observed at 25 and $28^{\circ} \mathrm{C}$. According to the thermal requirements, $S$. articulatus may present 6,4 to 9,8 generations/year in the citrus areas of the State of São Paulo (Araraquara, Barretos, Bebedouro, Limeira and São José do Rio Preto). The highest fecundity of S. articulatus occurred from 50 to $70 \% \mathrm{RH}$. The most suitable $\mathrm{RH}$ was $70 \%$ and in this condition occurred the highest fecundity, highest net reproductive rate $\left(R_{o}\right)$ and finite increase rate

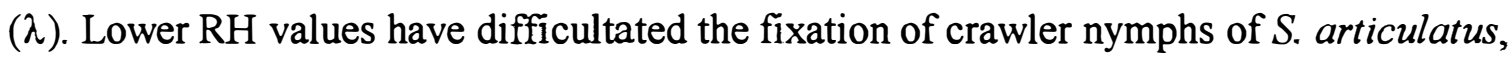
and the first intar is critical because of the highest mortality, regardless temperature or RH. Immature females have two instars (one crawler and one fix), while immature males 
have four instars (one crawler and three fixes). S. articulatus showed preference to fix on young leaves of Citrus limonia. The citrus variety (cultivar) was the preferred one when compared with "Pera, Natal and Valencia" and with Citrullus silvestris wich is considered the most suitable host to rear the rufous scale, because it gives a good insect viability and because its fruit presents high durability. After de scale fixation ten damages are irreversible ones. The level of control of $S$. articulatus was 30 scales/leaf, corresponding to $7 \%$ of severity, based on the photosynthesis rate, stomatic conductance and transpiration rate. 


\section{INTRODUÇÃO}

O Brasil é o maior produtor mundial de citros, com $34 \%$ da produção total, o equivalente a 428 milhões de caixas de laranja, sendo que o Estado de São Paulo detém $74 \%$ da produção nacional (Neves, 1997). Grande parte do custo de produção na citricultura é direcionado ao controle de pragas e doenças, que chegam, em muitos casos, a ser limitantes à cultura.

Pragas, tais como, moscas-de-frutas, ácaros, cigarrinhas, bicho-furão, minadora-dos-citros, são consideradas chaves, enquanto que as cochonilhas, com ênfase às de carapaça, são consideradas de menor importância, podendo ser prejudiciais à cultura sob determinadas condições climáticas (Nakano, 1985), determinados tratos culturais (Pinto et al., 1994) e em agroecossistemas citrícolas desequilibrados pelo uso excessivo de agrotóxicos (Herrera Aranguena, 1969 e Gravena, 1990). Entretanto, elas representam o grupo de pragas menos conhecido e seu controle é feito de forma empírica, sem o conhecimento do nível de dano das mesmas.

Dentre a quase dezena de espécies de cochonilhas que ocorrem em Citrus, destaca-se, para o Estado de São Paulo, Selenaspidus articulatus (Morgan, 1889), diaspidídeo, de carapaça e que juntamente com outros representantes da família, é praga de grande importância na agricultura (Ferris, 1938).

Segundo Mackenzie (1956) esta praga seria originária da África, sendo hoje registrada na Ásia, Austrália e América Central e do Sul. No Brasil, foi por muito tempo constatada apenas no Pará (Lepage, 1938). No final da década de 70, foi referida no Rio de Janeiro (Racca Filho \& Cassino, 1980), sendo observada pela primeira vez no Estado de São Paulo em 1981 e mais intensamente na safra 1984/85 na região de Bebedouro (Prates et al., 1985 e Prates, 1997). 
Os prejuízos desta praga, conhecida como pardinha, é resultado do seu ataque às folhas e frutos de Citrus. Causa prejuízos diretos, pela injeção de salivas digestivas, que resultam em auréolas amareladas em folhas e frutos. Em altas populações, causam murchamento e queda de folhas, com prejuízos à fisiologia da planta. Os frutos não amadurecem uniformemente, perdendo a qualidade (Beingolea, 1969 e Bartra, 1974).

Temperatura, umidade relativa do ar e precipitação pluviométrica têm sido referidos como os principais fatores controladores de populações de $S$. articulatus. Embora alguns autores relatem que o pico populacional da praga seja no período quente e chuvoso (Pinto, 1995), é sabido que nestes períodos a ação de fungos entomopatogênicos pode ser limitante à evolução do inseto (Lucchesi et al., 1986). Como conseqüência, períodos de longa estiagem, na ausência destes agentes entomopatogênicos, podem determinar o crescimento populacional desta praga. Dentre os predadores, os coccinelídeos são considerados os mais importantes (Prates et al., 1985 e Leão Neto et al., 1986). Segundo Watanabe \& Yoshii (1992) os microhimenópteros parasitóides não têm grande ação sobre a praga em São Paulo.

O objetivo da presente pesquisa foi avaliar o desenvolvimento de $S$. articulatus em diferentes temperaturas e umidades relativas do ar, para definir áreas no Estado de São Paulo nas quais esta praga tenha maior possibilidade de aumentar o seu nível populacional e, conseqüentemente, causar maiores prejuizos. Estas informações permitirão, ao lado de um estudo correlacionando a área foliar danificada pela praga e a atividade fotossintética da planta cítrica, definir o nível de controle da cochonilha. $\mathrm{O}$ estudo bioecológico e a determinação do nível de controle, de uma forma conjunta, possibilitarão a racionalização do controle de $S$. articulatus. 


\section{REVISÃO DE LITERATURA}

\subsection{Aspectos taxonômicos}

A cochonilha-pardinha Selenaspidus articulatus (Morgan, 1889) foi originalmente descrita no gênero Aspidiotus (Bouché), em 1889, e tem as seguintes sinonímias, segundo McKenzie (1956) e Ferris (1938): Aspidiotus articulatus (Morgan), Aspidiotus (Selenaspidus) articulatus (Morgan), Pseudaonidia articulata (Morgan) e Pseudaonidia articulata var. simplex de Chermog.

A identificação baseia-se nos seguintes caracteres: presença de carapaça no estágio adulto, medindo cerca de $2 \mathrm{~mm}$ de diâmetro; ausência de olhos e presença de antenas reduzidas a um tubérculo nas fêmeas, que pode ou não conter cerdas; ausência de pernas a partir do segundo ínstar; presença de pigídio (fusão dos segmentos abdominais 4-8) e de glândulas especializadas para a produção e distribuição de cera (macrocondutores, lóbulos e espinhos, pente e tubérculos glandulares); cabeça e tórax fundidos; ausência de tentórios, exceto as fossetas tentoriais rudimentares; cabeça e abdômen fracamente esclerotizados e conduto ejaculador do macho muito alargado e fortemente esclerotizado (Ferris, 1938).

A fêmea é amarela, medindo cerca de $2 \mathrm{~mm}$ de diâmetro e com escamas nos dois primeiros ínstares, tendo, a partir daí, cor variável de castanho claro a cinza (Bartra, 1974), e apresenta uma constrição característica entre o mesotórax e o metatórax, ou seja, a região anterior (prossoma) semicircular, separada da região posterior (póssoma) por uma profunda constrição. O prossoma apresenta um distinto esporão de cada lado (Williams \& Watson, 1988). 
Esta espécie é identificada por meio de preparações microscópicas, sendo principalmente utilizada a estrutura marginal do pigídio. Uma descrição detalhada da espécie foi feita por Ferris (1938) e Balachowsky (1951).

\subsection{Biologia}

Segundo Bartra (1974), a ninfa de primeiro instar (migrante) de $S$. articulatus, é a única fase móvel da cochonilha, e, dura cerca de 3 horas até se fixar; é de coloração alaranjada e apresenta olhos simples e antenas. Logo após fixar-se, começa a produzir uma secreção cerosa sobre o dorso, que vai se transformando em carapaça, e o corpo da cochonilha "incha", adquirindo um formato cônico. Nesta fase, ocorre a primeira ecdise. A ninfa de segundo ínstar é bem maior que a de primeiro e a sua coloração é amarelo claro. A fêmea mede cerca de 1,3 mm de comprimento e $1,9 \mathrm{~mm}$ de largura, com a carapaça atingindo cerca de $1,9 \mathrm{~mm}$ de diâmetro (Bartra, 1974). Dziedzick \& Karnkowski (1990) descreveram a carapaça da fêmea como sendo redonda, levemente convexa, transparente e marrom, com 2 a 2,5 mm de diâmetro.

No segundo ínstar, os indivíduos que originarão machos começam a se diferenciar das fêmeas. A carapaça da ninfa do macho é oval, pouco mais escura que a da fêmea (Bergmann et al., 1988). Beingolea (1969) citou que as ninfas dos machos são facilmente separadas das de fêmeas, antes mesmo do aparecimento das características externas visíveis. Neste caso, os olhos que ainda não são visíveis, apresentam-se com formato de escudo, com duas protuberâncias ântero-laterais.

Bartra (1974) diferenciou o macho da fêmea de S. articulatus, na fase de pré-pupa, a qual é evidenciada, no macho, pelo delineamento das pernas, asas, antenas e aedeagus recobertos por um envoltório. $\mathrm{Na}$ fase de pupa, o macho é caracterizado pelos apêndices visíveis e ocorre a eliminação de um envoltório ceroso no pigídio, proveniente da pré-pupa. O macho é alado, de coloração rosada, com $0,8 \mathrm{~mm}$ de comprimento e 0,2 $\mathrm{mm}$ de largura. A cabeça apresenta um par de olhos dorsais e um par de olhos ventrais, 
assim como duas antenas longas. No tórax, localiza-se uma placa dorsal transversalmente disposta, fortemente esclerosada.

Beingolea (1969) considerou que $S$. articulatus apresenta três ínstares sésseis, pois a ninfa de primeiro ínstar, para se fixar, deveria sofrer ecdise. Porém, Bartra (1974) relatou apenas dois ínstares sésseis, fato também mencionado por Gonçalves \& Lima (1980).

O período de incubação da pardinha é muito rápido (Bartra, 1974). Da fase migrante até a primeira ecdise são necessários 9 dias no verão $\left(27^{\circ} \mathrm{C}\right)$ e 13 dias no inverno $\left(17^{\circ} \mathrm{C}\right)$, passando para o segundo ínstar, séssil, que dura 8 dias no verão e 15 dias no inverno. $\mathrm{O}$ autor considerou ainda uma fase específica dentro do terceiro ínstar, da segunda ecdise até a formação da fềmea, que durou 15 dias no verão e 19 dias no inverno. Para a fềmea tornar-se sexualmente madura, são necessários 32 dias no verão e 47 dias no inverno. O macho apresenta um ciclo mais rápido, variando de 26 a 38 dias, e vive apenas 19 ou 22 horas, respectivamente, no verão e inverno. A razão sexual é de 1:1,5 (macho: fêmea) e o macho é indispensável para a reprodução.

Beingolea (1969) considerou que a duração do ciclo total (ovo a adulto) para o macho dura 30 dias e para a fềmea 45 dias à temperatura de 25 a $28^{\circ} \mathrm{C}$ no verão com oviposição de 122 migrantes.

Herrera Aranguena (1964) determinou que esta praga apresenta 4 gerações anuais, com um ciclo de vida de $52-59$ dias $\left(23^{\circ} \mathrm{C}\right)$ no verão e $132-168$ dias $\left(16^{\circ} \mathrm{C}\right)$ no inverno e primavera na Costa Central do Peru.

\subsection{Distribuição geográfica e importância econômica em Citrus}

S. articulatus foi registrada em vários países do mundo, sendo que McKenzie (1956) levantou a hipótese de que esta cochonilha teria como centro de origem a África. 
Bartra (1974) citou sua ocorrência no Brasil, Peru, Guiana Britânica, México, Índia, Panamá, Trinidad-Tobago, Equador, Bolívia, EUA (Flórida), África (Uganda).

A pardinha foi referida causando sérios prejuízos em citros no Equador (Yust, 1958) e em Cuba (Dziedzick \& Kankowski, 1990), porém Dekle (1976) não a considerou como uma praga de importância na Flórida (EUA).

No Peru, Herrera Aranguena (1964) citou S. articulatus e Lepidosaphes beckii Newman como sendo as principais cochonilhas que atacam citros. Beingolea (1969) relatou que a cochonilha pardinha era a principal praga das plantações de citros do Peru.

Dziedzick \& Kamkowski (1990) citaram que esta cochonilha tem sido relatada na Ásia, América do Sul e Central e na Austrália, e que na Europa existem apenas registros de sua ocorrência em casas-de-vegetação. A preocupação dos autores é de que a pardinha poderia aclimatar-se na Polônia.

A cochonilha $S$. articulatus foi relatada no Brasil ocorrendo apenas no Estado do Pará (Lepage, 1938 e Silva et al. ${ }^{1}$ citados por Menezes \& Cassino, 1984). No entanto, Racca Filho \& Cassino (1980) comentaram o surgimento da pardinha em pomares cítricos no Estado do Rio de Janeiro no final da década de 70, alertando que este diaspidídeo poderia se tornar muito prejudicial à citricultura do Estado, podendo disseminar-se para outros centros citrícolas. Gonçalves \& Lima (1980) também relataram a ocorrência desta praga em pomares cítricos no Estado do Rio de Janeiro, nos municípios de Seropédica, Itaguaí e Itaboraí.

Menezes \& Cassino (1984) relataram a associação da pardinha a plantas cítricas em alguns municípios do Estado do Espírito Santo. A ocorrência de $S$. articulatus no Estado de São Paulo foi relatada por Prates et al. (1985), infestando citros em 1981 e mais intensamente em 1984/85. Para este mesmo Estado, Watanabe \& Yoshii (1992) registraram a pardinha infestando pomares de citros nos municípios de Bebedouro, Terra Roxa, Araraquara, Viradouro, Catanduva, Paraíso, Taiuva, Taiaçu,

\footnotetext{
${ }^{1}$ SILVA, A.G.d'A et al. Quarto catálogo dos insetos que vivem nas plantas do Brasil, seus parasitos e predadores, parte II, 1968. 622p.
} 
Barretos, Jaboticabal, Monte Azul Paulista, Piranji, Guariba, Pitangueiras, Cajobi, Olímpia, Uchoa, Novo Horizonte, Mogi-Guaçu, Porto Feliz e Tatui. Prates et al. (1998), citaram que a colhonilha $S$. articulatus encontra-se disseminada por todo Estado de São Paulo, causando sérios prejuízos aos produtores, com perdas de peso de frutos de até $30 \%$, por provocar maturação precoce, além de outros danos, causando manchas, descoloração e queda de folhas e frutos. Segundo Gouvea et al. (1998) foram registradas diversas ocorrências dessa espécie causando danos consideráveis, no município de Santa Inês, no Sudoeste da Bahia.

Yust (1958) citou que a pardinha causa sérios danos em citros, provocando áreas amareladas nas folhas, desfolhamento, grande redução na produção e na qualidade dos frutos.

Herrera Aranguena (1964) determinou que os danos de S. articulatus são proporcionais à sua população. Quando em pequenas populações, ataca unicamente as folhas e os frutos. Entretanto, quando a infestação é alta, ataca também as hastes e os ramos verdes. $\mathrm{O}$ ataque a frutos leva à desuniformidade da coloração.

Os prejuízos causados pelo ataque da pardinha em citros são detalhados por Bartra (1974). Os danos diretos são causados principalmente pela picada da cochonilha, que injeta uma saliva digestiva, causando as auréolas amareladas nas folhas e nos frutos. Os danos indiretos são derivados desta picada, promovendo murchamento das folhas, com reflexos na fotossintese. Gravena et al. (1995) referiu que plantas atacadas pela praga sofrem prejuízos no crescimento e na produção, pois o fruto atacado fica deformado e não cresce. Em frutos novos, o local de ataque fica deprimido, o tamanho do fruto é reduzido, bem como a quantidade de suco. Plantas novas, com até 4 anos de idade, são as mais prejudicadas por esta praga. 


\subsection{Plantas hospedeiras}

Dekle (1976) mencionou 50 plantas hospedeiras da cochonilha pardinha, incluindo os gêneros Citrus, Coffea, Jasminum, Gardenia, Ligustrum, Magnolia, Mangifera, Olea, Pandonu, Sambucus, Tilia e várias espécies de palmeiras.

Wille (1952) e Bartra (1974) citaram diversos hospedeiros de $S$. articulatus nas regiões tropicais e sub-tropicais do mundo como sendo cítricos em geral, além de graviola (Anonna muricata), abacate (Persea americana), pimenta (Piper nigrum), cherimólia (Anonn cherimolia), azeitona (Olea europea), seringueira (Hevea sp.), mogno (Swietenia macrophylla), tamarindo (Tamarindus indica), coco (Coccus nucifera), mamea (Mammea americana), cicas (Cycas circinales), maracujá (Passiflora edulis), uva (Vittis vinifera), manga (Mangifera indica), louro (Laurus nobilis) e outras, incluindo palmeiras, bananeiras e tangerinas.

Beingolea (1969) citou que existem variações de danos dependendo da cultura. Assim, relatou danos severos em oliveiras, mencionando infestação em toda a superficie da folha.

Cassino et al. (1986) observaram, pela primeira vez, no município de Vassouras (RJ), o diaspidídeo $S$. articulatus em folhas de tamarindeiro (T. indica).

No Brasil, pela primeira vez, Bergmann et al. (1988) citaram a presença da pardinha em folhas de seringueira em Olímpia, no Estado de São Paulo. Em altas infestações, as folhas apresentavam-se totalmente recobertas pela praga.

Ferraz (1997) observou, no município de Bebedouro (SP), infestação de S. articulatus na planta Mimosa caesalpiniaetolia ("sansão do campo"), utilizada como cerca viva em pomares de Citrus.

Pereira et al. (1998) em levantamento de hospedeiros de $S$. articulatus na Barra da Tijuca (RJ), em ornamentais e frutíferas, constataram que, dos 23 vegetais nos quais coletaram a cochonilha, 10 eram novos hospedeiros de $S$. articulatus, ou seja, Chrysolidocarpus lutescens, Clusia sp., Delaniz regia, Eugenia uniflora, Hibiscus pernambuscensis, Mangifera indica, Marneria edulis, Morus alba, Psidium guajava, Sizygium cuminii e Sponde lutea. Entre os novos hospedeiros, S. cuminii foi o que 
apresentou maior ocorrência de S. articulatus, com $42 \%$ das plantas monitoradas apresentando a cochonilha.

\subsection{Aspectos ecológicos e época de ocorrência de $S$. articulatus}

Herrera Aranguena (1969) considerou que o uso excessivo de produtos químicos na citricultura do Peru elevou o "status" de S. articulatus e L. beckii de segundárias à pragas chave.

Altas populações desta praga podem estar correlacionadas com longos períodos de déficit hídrico, que desfavorecem os fungos entomopatogênicos, os quais a mantêm em equilíbrio (Nakano, 1985), ou com a poeira, gerada pelo uso de grades ou circulação de veículos que favorece a ocorrência de cochonilhas em citros,

principalmente as de carapaça (Gravena, 1990 e Pinto et al., 1994). Gravena (1990) ainda citou outras 4 espécies que são muito favorecidas pela poeira: Parlatoria pergandii Comstok., P. ziziphus Lucas, Unaspis citri Comstok e Mycetaspis personata Comstok.

Surís (1985) determinou a influência do porta-enxerto sobre a cochonilha pardinha. Verificou que a 'lima-da-Pérsia', enxertada sobre laranja 'Agrio', apresentou maior população desse diaspidídeo em relação ao mesmo material sobre 'Rugoso' e 'Cleópatra'. As cochonilhas preferem, em geral, folhas maduras (velhas) em relação às mais novas.

Surís \& Varona (1988) avaliaram a distribuição de S. articulatus em pomares de laranja em Cuba, durante 1981/83 e observaram que a distribuição desta praga foi heterogênea dentro do pomar e dentro da planta.

Perruso \& Cassino (1993) estudaram a flutuação populacional de $S$. articulatus em citros. Observaram uma grande regularidade quanto às épocas de ocorrência, registrando as maiores infestações no período quente e úmido (setembro a janeiro) e as menores nos período frio e seco (maio a julho). 
Pinto (1995) também detenninou a dinâmica populacional de $S$. articulatus, no município de Taquaritinga (SP), observando que a população da cochonilha pardinha apresentou picos em todas as estações do ano. Entretanto, os maiores níveis ocorreram nos meses quentes e úmidos. Este autor observou ainda que a face de exposição norte e a região interna da planta ofereceram melhores condições para a sobrevivência da cochonilha. A face superior da folha apresentou-se mais infestada do que a inferior, sendo a região mais próxima do pecíolo a mais afetada.

Pereira et al. (1997) avaliaram a flutuação populacional de $S$. articulatus no Estado do Rio de Janeiro e constataram que o pico populacional ocorreu em abril, com comportamento atípico, pois usualmente ela prefere condições quentes e úmidas. Dominici et al. (1997), em Jaboticabal (SP), estudaram o local em que se encontra a maior concentração do inseto, comparando tronco, folhas da "saia", parte interna e externa da planta. Observaram maior concentração na parte interna das plantas, sugerindo este local como o mais adequado para amostragens da cochonilha.

Silva Filho et al. (1998) observaram picos populacionais variáveis de $S$. articulatus, dependendo do ano em que se realizou a amostragem, na região do Parque da "Gleba E" (RJ).

\subsection{Controle biológico}

Herrera Aranguena (1964) não constatou, no Peru, nenhuma espécie de parasitóide que controlasse a pardinha, pois o máximo de parasitismo obtido fora de 5,6\%, pelos parasitóides Aphytis chrysomphali Mercet e Aspidiotiphagus [Encarsia] lounsbury Berl \& Paoli. O autor citou ainda que, no Peru, não se conhecia a ação dos predadores como controladores desta praga, situação bem diferente dos EUA (Mumma ${ }^{2}$ citado por Herrera Aranguena, 1964), onde existia uma ampla gama de espécies de predadores conhecidas.

${ }^{2}$ MUMMA MARTIN, H. Annotated list of predators and parasites associated with insects and mites on Florida citrus. Geinsville: University of Florida/Agricultural Experiment Station, ?, 1961. (Boletim, 634). 
Além de estudar a biologia de $S$. articulatus, Bartra (1974) estudou alguns aspectos dos inimigos naturais desta cochonilha, destacando Aphytis roseni De Bach \& Gordh, parasitóide introduzido da África. Segundo o autor, $A$. roseni é responsável por $70 \%$ de controle do diaspidídeo no Peru, valor este muito superior ao alcançado pelas espécies nativas $A$. chrysomphali e $E$. lounsburyi, que são responsáveis por parasitismo de apenas 4 a $6 \%$.

Watanabe \& Yoshii (1992) estudaram o parasitismo da pardinha, a partir de coleta de folhas infestadas pela cochonilha, em pomar de laranja 'Valência', no município de Brotas (SP), num local que recebia aplicações do inseticida methidathion. Através do exame das carapaças perfuradas, em laboratório, determinaram que os índices de parasitismo variaram de 2,1\% (julho de 89 ) a 22,0\% (abril de 90 ).

Watanabe et al. (1994) estudaram o parasitismo da cochonilha pardinha, por microhimenópteros em citros, nas regiões de Jaguariúna e Limeira (SP), por meio da contagem de carapaças de fêmeas com orificios de saída dos parasitóides. Verificaram que, nas épocas de menor incidência da praga, ocorreu a maior quantidade de parasitóides e que o pico de parasitismo na maioria das áreas ocorreu em agosto de 1991, indicando maior ocorrência de parasitismo nos meses frios e secos do ano. Por outro lado, Watanabe (1997) observou parasitismo inferior a $1 \%$ em três pomares na região de Limeira (SP).

O parasitismo de $S$. articulatus, em pomar de laranja 'Pera', no município de Taquaritinga (SP), foi estudado por Santana et al. (1994), mediante contagem de pupas do parasitóide e seus orifícios de saída na carapaça. A maior ocorrência de parasitóides foi nos meses de julho, novembro e janeiro, sendo que as ninfas de $2^{\underline{Q}}$ instar foram as mais parasitadas, com mortalidade, em janeiro, de 40 e $55 \%$, respectivamente, para fêmeas e machos.

Os coccinelídeos são importantes inimigos naturais de cochonilhas de carapaça em citros (Mariconi, 1963). Prates et al. (1985), a partir de observações sobre a cochonilha S. articulatus no Estado de São Paulo, referiram como predadores Chrysopa sp., Pentilia egena Mulsant e Coccidophilus citricola Brèthes. 
Leão Neto et al. (1986) observaram que a cochonilha pardinha é predada por vários coccinelídeos em Jaboticabal (SP), como C. citricola. Lucchesi et al. (1986) observaram Chrysopa sp., Azya luteipes Mulsant e P. egena predando S. articulatus em pomares de laranja em Monte Azul Paulista (SP).

Foi observado por Santana et al. (1994), estudando aspectos ecológicos da cochonilha pardinha na região de Taquaritinga (SP), que os fungos entomopatogênicos ocorreram mais intensamente em janeiro, principalmente sobre ninfas de $2^{\circ}$ instar (fêmeas) e adultos (fềmeas), provocando mortalidade variável de 40 a $65 \%$.

Prates et al. (1998) observaram, em pomares cítricos no Estado de São Paulo, a presença dos coccinelídeos e crisopídeos predando formas imaturas $(80 \%)$ e adultos $(20 \%)$ da S. articulatus. Foram citados: P. egena; A. luteipes; Cycloneda sanguinea (L.); C. citricola; Chrysopa sp.; os coccinelídeos foram encontrados em todos os municípios em cerca de $35,6 \%$ das plantas. Os crisopídeos também estiveram presentes em todos os municípios, e numa ocorrência de $57,5 \%$ das plantas. Em pequena freqüência, foram observados parasitóides dos gêneros Aphytis e Encarsia e fungos dos gêneros Fusarium, Aschersonia, Nectria e Myriangium, ocorrendo em $25 \%$ de plantas.

Xavier et al. (1997) avaliaram a capacidade de predação de Chrysoperla externa (Hagen) sobre $S$. articulatus e demonstraram que as larvas maiores ( $3^{\circ}$ instar) necessitam consumir mais para se transformarem em pupas e darem origem a adultos competitivos com os da natureza. Cada crisopídeo chegou a predar 45 cochonilhas. Avaliaram a eficiência de predação de $P$. egena e concluíram que as diferentes fases de um indivíduo do coccinelídeo predaram 21,0 machos e 44,0 fêmeas de $S$. articulatus.

Azevedo et al. (1998) avaliaram o parasitismo de $S$. articulatus por microhimenópteros, em 102 propriedades do Rio de Janeiro. O parasitismo, em geral, foi baixo, variando de 2 a 7\% por Aphytis spp. Pereira et al. (1998), em levantamentos quinzenais realizados também no Rio de Janeiro, avaliando o parasitismo de $S$. articulatus em ornamentais e frutíferas, constataram em 1996 e 1997, baixos parasitismos, sendo que o parasitismo por Encarsia spp. chegou a 8,8\% (abril/97), com uma média de $3,2 \%$. 


\subsection{Relação entre infestação de plantas por pragas e doenças e variáveis fisiológicos}

\subsubsection{Escalas diagramáticas}

A avaliação da intensidade do ataque de pragas ou doenças é de suma importância na quantificação dos danos causados às plantas hospedeiras, e, conseqüentemente na tomada de decisão de controle das mesmas (Amorim et al., 1995). Um dos métodos utilizados para a determinação da porcentagem de tecidos da planta ocupados por lesões de patógenos e/ou insetos, é aquele que utiliza escalas diagramáticas, nas quais são representadas diferentes níveis de infestação.

Para elaboração destas escalas existem algumas limitações (Amorim et al., 1995), como o treinamento prévio de avaliadores, o que, em alguns casos, tem dificultado sua utilização. Entretanto, nos últimos anos, esta técnica tem sido cada vez mais utilizada, em condições de campo, e o treinamento dos avaliadores tem sido facilitado com os recursos computacionais.

Embora este método seja bastante difundido na área da fitopatologia (Amorim et al., 1993 e 1995), muito pouco se tem feito em entomologia, praticamente inexistindo trabalhos relacionando escalas diagramáticas com danos causados por insetos.

\subsubsection{Exemplos de relações entre presença de patógenos e fotossíntese}

A fotossíntese é o processo através do qual a energia luminosa é transformada em açúcares que são facilmente utilizados pela respiração. Todo processo resume-se na oxidação da água (retirada de elétrons com liberação de oxigênio) e na redução do dióxido de carbono para formar compostos orgânicos, como carboidratos (Salisbury \& Ross, 1992). 
Segundo Pascholati e Leite (1995), a respiração e a fotossíntese constituem funções básicas das plantas e o balanceamento entre elas está diretamente relacionado com o estado geral das plantas e com a qualidade dos produtos por elas fornecidos. Em termos gerais, a taxa de respiração aumenta em um tecido doente ou injuriado, e a taxa de fotossintese tende a diminuir nestas condições.

Poucos são os trabalhos que relacionaram a intensidade de doença com o efeito desta sobre as variáveis fisiológicas. Baastians (1991) quantificou a redução da taxa fotossintética em folhas de arroz infectadas pela brusone do arroz, causada por Pyricularia grisea. Goodwin (1992), constatou significativa alteração na fotossíntese de folhas de feijoeiro atacados por ferrugem bacteriana. Bassanezi et al. (1997) estudando os efeitos da antracnose na eficiência fotossintética do feijoeiro observaram redução de $50 \%$ da taxa fotossintética nas folhas com 5 a $10 \%$ de área lesionada. Na faixa de 25 $70 \%$ a taxa fotossintética líquida era, em muitos casos, nula ou negativa. 


\section{MATERIAL E MÉTOdOS}

O trabalho foi conduzido no Laboratório de Biologia de Insetos do Departamento de Entomologia, Fitopatologia e Zoologia Agrícola da Escola Superior de Agricultura “Luiz de Queiroz" (ESALQ), da Universidade de São Paulo (USP).

Iniciou-se o experimento com a coleta de fềmeas de Selenaspidus articulatus (Morgan, 1889) em pomares de citros, atacados pela praga, em várias regiões do Estado de São Paulo (Limeira, Barretos, Araraquara, Bebedouro, São José do Rio Preto). Para os estudos bioecológicos, as cochonilhas foram mantidas, durante o seu desenvolvimento, sobre folhas de mudas de limão 'Cravo' (Citrus limonia) (criação estoque). As plantas foram mantidas em tubetes plásticos (pretos) de $20 \mathrm{~cm}$ de altura por $1,5 \mathrm{~cm}$ de diâmetro, tendo como substrato vermiculita e composto vegetal. Elas foram podadas e adubadas com NPK, periodicamente, a fim de manter a regularidade na emissão de brotações. As plantas foram dispostas em grades de metal, em bandejas de plástico (Figura 1A), mantidas em câmaras climatizadas, à temperatura de $25 \pm 2^{\circ} \mathrm{C}$, umidade relativa de $60 \pm 10 \%$ e fotofase de 14 horas.

3.1 Biologia, em diferentes temperaturas, exigências térmicas e tabela de vida de fertilidade de $S$. articulatus

\subsubsection{Biologia em diferentes temperaturas}

O ciclo biológico foi estudado mantendo-se também a cochonilha sobre folhas de mudas de limão 'cravo'. Os ensaios foram conduzidos em câmaras 
climatizadas (BOD), reguladas a $18,20,22,25,28,30$ e $32^{\circ} \mathrm{C}$, umidade relativa de $60 \pm 10 \%$ e fotofase de 14 horas. O delineamento experimental foi inteiramente casualizado, em 50 repetições (insetos) distribuídos em quatro mudas de limão 'cravo'. Os dados foram submetidos à analise da variância, sendo as médias comparadas pelo teste de Duncan, ao nível de 5\% de probabilidade.

As infestações foram realizadas com insetos recém-eclodidos, da criação estoque, os quais foram transportados, com estilete fino, para as folhas das plantas (Figura 1B). Todas as observações foram diárias, realizadas com auxílio de microscópio estereoscópico.

Em cada uma das sete (7) temperaturas foram observados as seguintes variáveis biológicas:

\section{Fase ninfal: duração dos ínstares e viabilidade}

O desenvolvimento ninfal foi acompanhado desde o momento em que os insetos, recém eclodidos, foram transferidos às folhas. Uma vez fixado na folha, cada indivíduo foi identificado com um círculo feito no vegetal, com caneta de retroprojetor (Figura 2).

Durante o desenvolvimento, o número de ínstares foi determinado pelas exúvias das ninfas incorporadas na carapaça visíveis somente ao retirá-las e verificando-se em lupa. No caso de machos, as exúvias são visíveis, sendo eliminadas por baixo da carapaça.

As medidas de comprimento e largura das fases de desenvolvimento e de adultos, de ambos os sexos, foram feitas com um medidor Wild MMS 235, acoplado a um microscópio estereoscópico.

Foi registrada a mortalidade desde a fixação em cada fase do desenvolvimento de fêmeas e machos. 


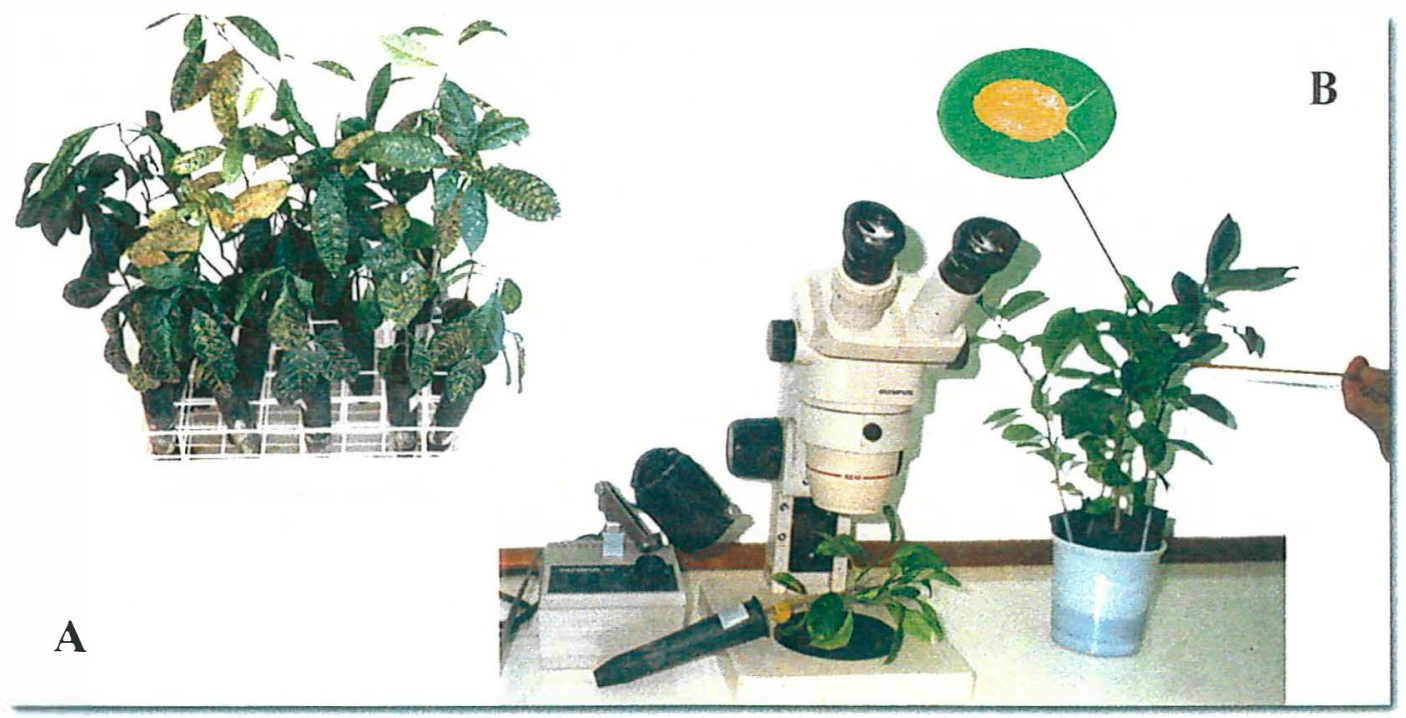

Figura 1. Bandejas plásticas contendo os tubetes com mudas de C. limonia infestadas com $S$. articulatus (A) e método de infestação de mudas com ninfas da cochonilha através de estiletes finos (B).

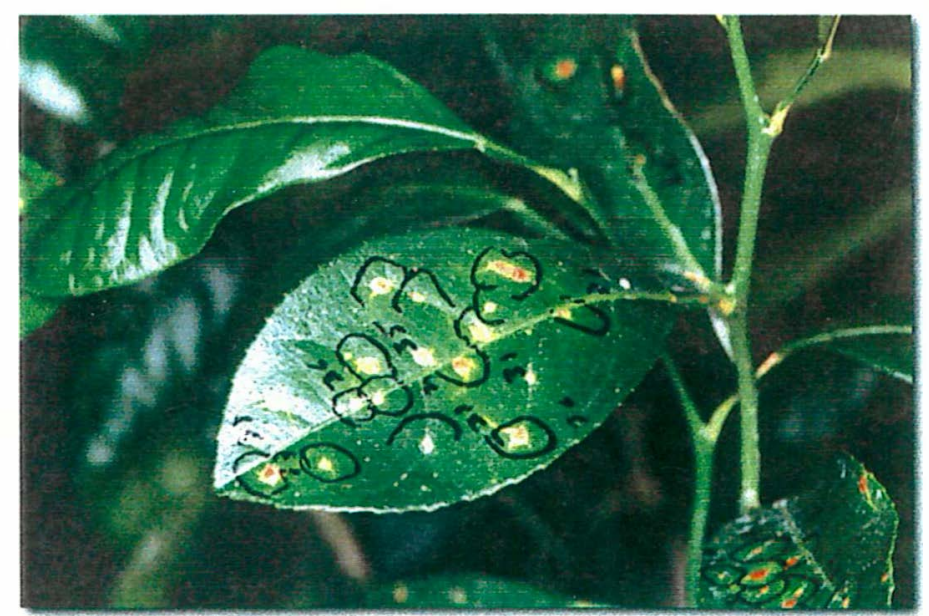

Figura 2. Marcação, com caneta de retroprojetor, dos indivíduos de S. articulatus observados nos ensaios de biologia, em folhas de C. limonia infestadas. 


\section{Fase adulta}

- Período de "pré-oviposição"

O período de "pré-oviposição" foi considerado como aquele compreendido desde a última ecdise até a eclosão da primeira ninfa móvel (migrante).

\section{- Fecundidade (nú mero de ninfas móveis ou migrantes por fêmea):}

Cada cochonilha fêmea foi isolada e identificada com círculos (Figura 2), conforme anteriormente citado. A capacidade de oviposição foi avaliada levantando-se a carapaça e contando-se, a cada 5 dias, os córions vazios.

\section{- Longevidade}

A longevidade foi observada de acordo com o sexo. Os machos foram separados e observados diariamente em pequenos tubos de vidro $(8,5 \times 2,5 \mathrm{~mm})$, tampados com filme plástico de PVC nas diferentes temperaturas; as fêmeas foram consideradas mortas, quando o seu corpo secava. A sobrevivência dos adultos nas diferentes condições térmicas foi analisada através de Weibull (Sgrillo, 1982).

\section{- Razão sexual}

$$
r s=\frac{f \hat{e r m e a s}}{\text { fêmeas }+ \text { machos }}
$$

A separação por sexo foi feita com base nas diferenças entre as carapaças, nas fêmeas, arredondadas e, nos machos, ovaladas. A razão sexual obtida, nas diferentes temperaturas, foi comparada através do teste não paramétrico de $\mathrm{X}^{2}$.

As durações dos períodos de desenvolvimento (ninfa móvel-adulto) e respectivas viabilidades, períodos de pré-oviposição, oviposição e fecundidade foram submetidos à análise da variância, sendo as médias comparadas pelo teste de Duncan, ao nível de $5 \%$ de probabilidade. 


\subsubsection{Exigências térmicas}

Com base nas durações das fases imaturas de desenvolvimento e do ciclo total (fase móvel-adulto), foram determinados os limites térmicos inferiores de desenvolvimento $(\mathrm{Tb})$ e constantes térmicas $(\mathrm{K})$ para machos e fềmeas desse inseto, através do método da hipérbole (Haddad \& Parra, 1984).

\subsubsection{Tabela de vida de fertilidade}

Foram elaboradas tabelas de vida de fertilidade em 6 temperaturas em que houve desenvolvimento do inseto $\left(18,20,22,25,28\right.$ e $\left.30^{\circ} \mathrm{C}\right)$ calculando-se $\mathrm{T}, \mathrm{r}_{\mathrm{m}}, \lambda \mathrm{e}$ $R_{o}$, de acordo com Silveira Neto et al. (1976).

\subsection{Observações morfológicas de $S$. articulatus}

Para observação da morfologia externa das diferentes fases de desenvolvimento de $S$. articulatus, foram comparadas duas técnicas de preparo dos espécimens para posterior observação ao microscópio eletrônico de varredura (M. E.V.):

1) Secagem no dessecador - os insetos, mortos, foram desidratados em dessecador, por, no mínimo $2 \mathrm{~h}$, sendo então feita a cobertura com ouro seguida de observações ao M.E.V.

2) Fixação e secagem ao ponto crítico - os insetos foram fixados em solução de glutaraldeído a $4 \%$ com tampão cacodilato $0,2 \mathrm{M} \mathrm{a} \mathrm{pH} \mathrm{7,2} \mathrm{por} 6 \mathrm{~h}$, seguida de imersão em $\mathrm{OsO}_{4}$ a $1 \%$ em tampão cacodilato $0,1 \mathrm{M} \mathrm{a} \mathrm{pH} \mathrm{7,2} \mathrm{por} 1 \mathrm{~h}$, desidratação em série de acetona diluída a $30 \%, 50 \%, 70 \%, 90 \%$ e três vezes a $100 \%$, ficando as amostras 10 minutos em cada diluição, com secagem ao ponto crítico com $\mathrm{CO}_{2}$ e posterior cobertura com ouro para observação ao M.E.V. (Kitajima \& Breno Leite, 1998). 
As amostras foram fixadas no porta espécimens ("stub") contendo quatro cochonilhas de $S$. articulatus em diferentes ínstares e os adultos (machos e fềmeas).

\subsection{Biologia de $S$. articulatus em quatro umidades relativas do ar}

O desenvolvimento de $S$. articulatus foi estudado em quatro umidades relativas $(30,50,70$ e $90 \pm 5 \%)$, mantidas em câmaras climatizadas, com temperatura de $25 \pm 2^{\circ} \mathrm{C}$ e fotofase de 14 horas, para todas as condições. Os insetos foram observados em folhas de mudas de limão 'cravo' de forma análoga ao item 3.1.

O delineamento estatístico foi inteiramente casualizado, com 50 repetições (insetos) distribuídas em 4 mudas de limão cravo. Os dados foram submetidos à analise da variância, sendo as médias comparadas pelo teste de Duncan, ao nível de $5 \%$ de probabilidade.

As variáveis biológicas avaliadas foram semelhantes àquelas do item 3.1., ou seja

- duração de ínstares e viabilidade da fase ninfal;

- períodos de pré oviposição, oviposição, longevidade, sobrevivência de adultos através de Weibull, e, razão sexual baseando-se nos adultos;

- tabela de vida de fertilidade.

\subsection{Números de gerações de $S$. articulatus em 5 regiões do Estado de São Paulo}

Foi determinado, com base em Parra (1995), o número de gerações para as cinco principais regiões citrícolas do Estado de São Paulo (Limeira, Bebedouro, Araraquara, São José do Rio Preto e Barretos) (Figura 3), tomando-se por base as normais climatológicas destas áreas. As normais climatológicas foram obtidas no Departamento de Ciências Exatas da ESALQ/USP. 


\subsection{Biologia comparada de $S$. articulatus no hospedeiro natural e alternativo}

Comparou-se a biologia de $S$. articulatus em quatro variedades de Citrus ('Hamlin', 'Natal', 'Pera' e 'Valência') (hospedeiros naturais), em relação a um padrão (testemunha), Citrullus silvestris, hospedeiro alternativo bastante adequado à criação desta espécie (Bartra, 1994) e recém introduzido do Peru para o Brasil.

Infestaram-se laranjas das diferentes variedades (Figura 4A) e de $C$. silvestris (Figura 4B) com ninfas móveis (migrantes) de $S$. articulatus, mantendo-se o material infestado em placas de Petri contendo algodão levemente umedecido na parte inferior (Figura 4A). Avaliaram-se:

- duração de ínstares e viabilidade;

- ciclo total (ninfa móvel-adulto).

O delineamento experimental foi inteiramente casualizado, sendo cada repetição distribuidas em quatro frutos verdes de laranja e de $C$. silvestris (50 ninfas móveis). Os dados foram submetidos à analise da variância, sendo as médias comparadas pelo teste de Duncan, ao nível de 5\% de probabilidade.

\subsection{Efeito da idade da folha de $C$. limonia na fixação de $S$. articulatus}

Utilizaram-se folhas de Citrus limonia de diferentes estágios de desenvolvimento, ou seja, localizadas no terço apical (folhas novas), mediano (folhas médias) e basal (folhas maduras). Realizaram-se testes de preferência com livre escolha, utilizando-se placas de Petri (15 cm de diâmetro), contendo no fundo uma camada de gesso, forrada com papel de filtro umedecido. As folhas de cada estágio foram transferidas para as placas de Petri (três folhas por placa) e dispostas de maneira eqüidistante, totalizando 15 repetições. Em seguida, foram liberadas no ponto central da placa 50 ninfas móveis (migrantes) de S. articulatus. As placas de Petri foram tampadas, 
vedadas com fita adesiva e mantidas no laboratório a $25^{\circ} \mathrm{C}$, umidade relativa de $60 \pm 10 \%$ e fotofase de 14 horas.

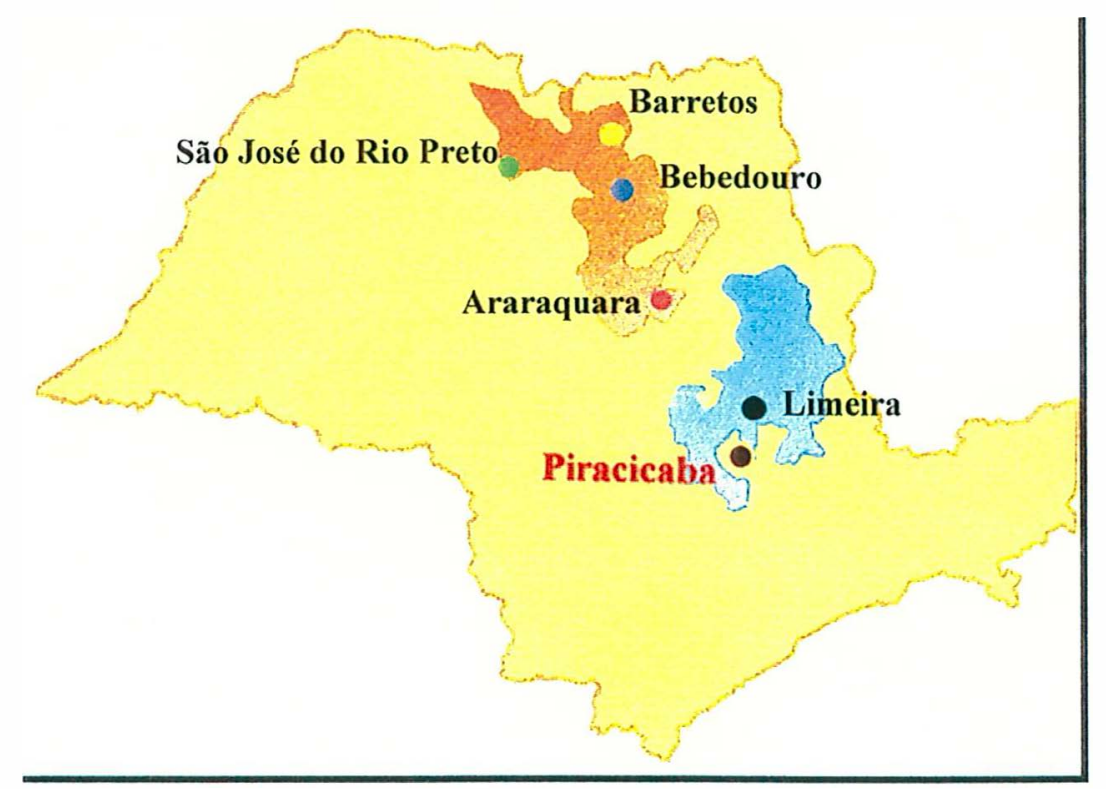

Figura 3. Mapa do Estado de São Paulo com cidades representativas das principais regiões citrícolas.
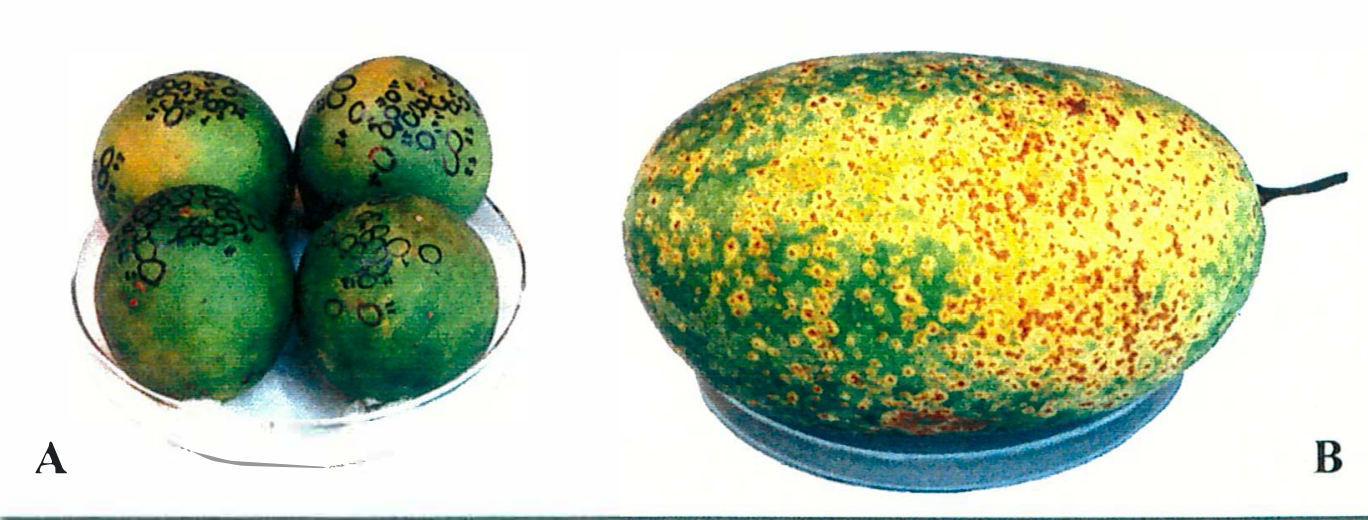

Figura 4. Frutos de Citrus (A) e C. silvestris (B) infestados com S. articulatus, utilizados nos ensaios. 
Vinte e quatro horas após o início do experimento, registrou-se o número de ninfas móveis fixadas nas folhas. Os resultados obtidos foram submetidos à análise de variância e as médias, comparadas pelo teste de Duncan, ao nível de $5 \%$ probabilidade.

\subsection{Determinação do nível de controle de $S$. articulatus com base na redução de parâmetros fisiológicos}

\subsubsection{Confecção de uma escala diagramática}

Foi confeccionada uma escala diagramática (em escala logarítmica) baseando-se em James (1974). Para elaborá-la, foram considerados sete níveis de infestação, sendo 0,5 e $35 \%$ os limites inferior e superior de áreas infestadas por $S$. articulatus respectivamente. Os níveis intermediários foram calculados com base no modelo logístico de Horsfall \& Barratt (1945).

A escala foi validada, individualmente, por 3 pessoas (avaliadores) com observação visual de 25 folhas de citrus, com diferentes níveis de infestação. Paralelamente, a severidade, nestas folhas, foi quantificada através de medidor de área foliar (LI-Cor, model LI-3000A) em base a desenhos em plásticos transparentes.

Os dados de severidade estimados pelos avaliadores e os dados obtidos com o medidor de área foliar, foram correlacionados, obtendo-se as retas de regressão (y $=\mathrm{a}+\mathrm{bx}$ ), para cada avaliador. O coeficiente angular da reta (b) e o ponto de intersecção da reta com o eixo y (a) representam a precisão do avaliador, devendo a e b serem os mais próximos de 0 e 1 respectivamente, para o avaliador ser acurado. O coeficiente de determinação da reta obtida $\left(\mathrm{R}^{2}\right)$ representa a precisão do avaliador. Para obtenção dos níveis de 0,5 e $35 \%$ de infestação as folhas foram infestadas previamente com ninfas móveis, colocando-as, com estilete fino, sobre folhas de limão 'cravo'. As infestações foram sucessivas, de forma a obter diferentes idades de cochonilhas e, conseqüentemente, níveis populacionais diferenciados confeccionando, assim, a escala diagramática (Figura 5). 


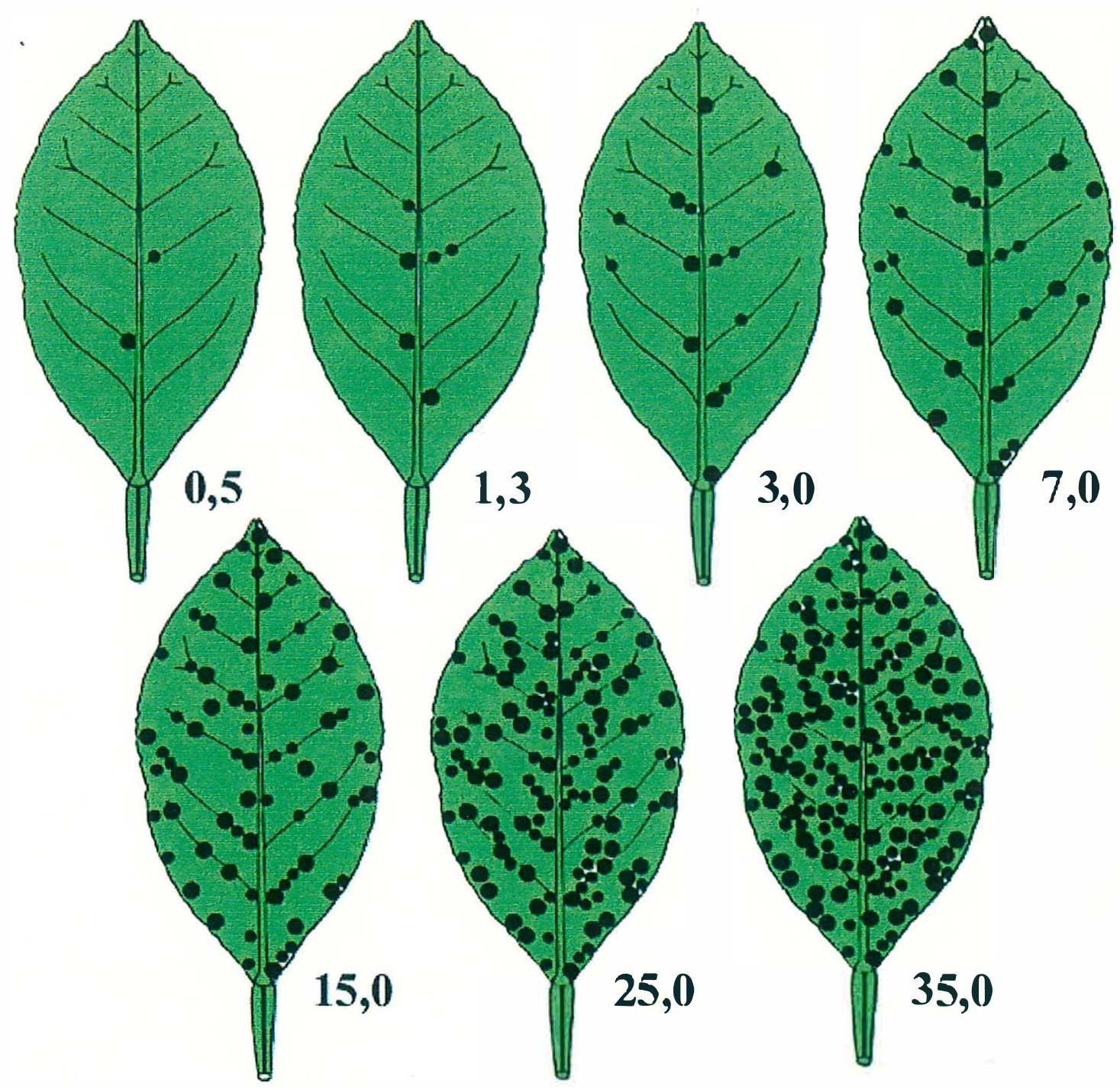

Figura 5. Escala diagramática utilizada para diferenciação dos níveis de infestação de S. articulatus em folhas de Citrus, com níveis variando de 0,5 a 35\%. 


\subsubsection{Avaliação de trocas gasosas}

Através do equipamento LI-6400 Portable Photosynthesis System (LiCor®) (Figura 6), foram medidas as variáveis fisiológicas: taxa líquida de fotossíntese, taxa de transpiração e condutância estomática em folhas de mudas de Citrus limonia.

As variáveis fisiológicas foram calculadas segundo Long \& Hällgren (1993).

Nas folhas infestadas, as medições foram realizadas, inicialmente, com os insetos fixados às folhas. Posteriormente, eles foram retirados, por meio de estiletes, procedendo-se à nova avaliação sem os insetos presentes.

As condições durante as avaliações foram:

1) Temperatura da folha dentro da câmara de análise: $25^{\circ} \mathrm{C}$; 2) Fluxo de ar pela câmara de análise: $500 \mu \mathrm{mol} \mathrm{s} \mathrm{s}^{-1}$ 3) Umidade relativa na câmara de análise: 30$50 \%$; 4) Diferencial de pressão de vapor d'água na superfície foliar (VpdL): 1,0-1,6; 5) Concentração de $\mathrm{CO}_{2}$ no ar entrando na camâra de análise: 360 a 380 ppm; 6) Fonte de luz: 6400-02 LED light source (comprimento de onda de 660 a $675 \mathrm{~nm}$ ); 7) Intensidade de irradiação: $500 \mu \mathrm{mol} \mathrm{m}^{-2} \mathrm{~s}^{-1}$.

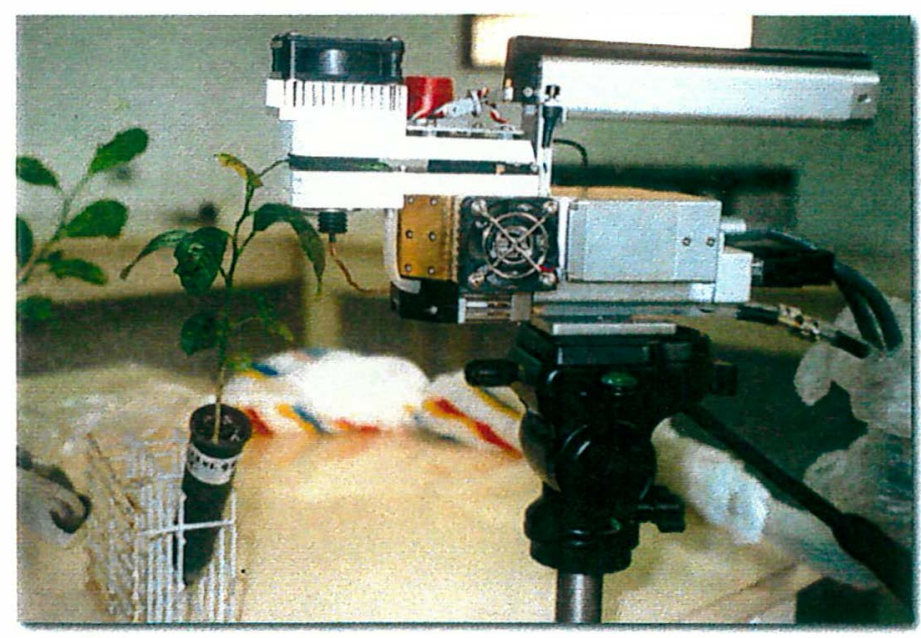

Figura 6. Equipamento, modelo LI-6400 Portable Photosynthesis System (Li-Cor®), utilizado para medição das variáveis fisiológicas. 
As variáveis fisiológicas (taxa líquida de fotossíntese, taxa de transpiração e condutância estomática) foram avaliadas a partir da estabilização da leitura, no equipamento mencionado (em média, para tal estabilização, foram necessários 5 minutos).

Correlacionaram-se os diferentes níveis de infestação de $S$. articulatus e os parâmetros fisiológicos através de uma regressão não-linear (Baastians, 1991).

$$
\mathrm{Px} / \mathrm{Po}=(1-\mathrm{x})^{\beta} \text {, na qual: }
$$

$\mathrm{Px}=$ valor do parâmetro medido na folha com infestação;

Po = média dos valores do parâmetro medido nas folhas controles;

$\mathrm{x}=$ severidade em proporção;

$\beta=$ parâmetro estimado.

O nivel de infestação, a partir do qual houve uma redução nos processos fisiológicos das plantas, foi considerado como nível de controle da praga (Figura 5). 


\section{RESULTADOS E DISCUSSÃO}

\subsection{Ciclo de desenvolvimento e comportamento de Selenaspidus articulatus (Morgan, 1889)}

O desenvolvimento de $S$. articulatus é variável dependendo do sexo, sendo que a fêmea apresenta dois ínstares ninfais (Figura 7). Segundo Beardsley \& Gonzalez (1975) em Diaspididae, ocorre a neotenia, fato concordante com a presente pesquisa. Por outro lado, os machos passam por quatro ínstares ninfais (Figura 7). No primeiro ínstar, não é possível distinguir o sexo; entretanto, a partir do segundo ínstar, isto já é possível. O terceiro e quarto ínstares são do tipo "pupóide" (Figuras 7D e 7E). Observações microscópicas realizadas no presente trabalho possibilitaram esclarecer as divergências surgidas entre Beingolea (1969) e Bartra (1974), com relação ao número de ínstares da fêmea. O primeiro autor afirmou que o inseto apresentava três ínstares, enquanto que, para Bartra (1974), existiam apenas dois ínstares. No presente estudo, determinou-se a ocorrência de dois ínstares, sendo o primeiro ínstar subdividido em duas fases, ou seja, a primeira ninfa móvel ou migrante (A) e a segunda ninfa séssil (B).

$\mathrm{Na}$ fase $\mathrm{B}$ ocorrem duas etapas, as quais são distinguidas pela coloração da carapaça, sendo na primeira inicialmente branca passando, na segunda, a apresentar uma extensão amarelada em torno da carapaça original. Alguns autores também subdividiram essa fase para outras espécies, como Aonidiella aurantii (Maskell) (Tashiro \& Beavers, 1968) e Quadraspidiotus perniciosus (Comst.) (Gonzalez, 1981), denominando as etapas de acordo com sua forma, no idioma de origem. 


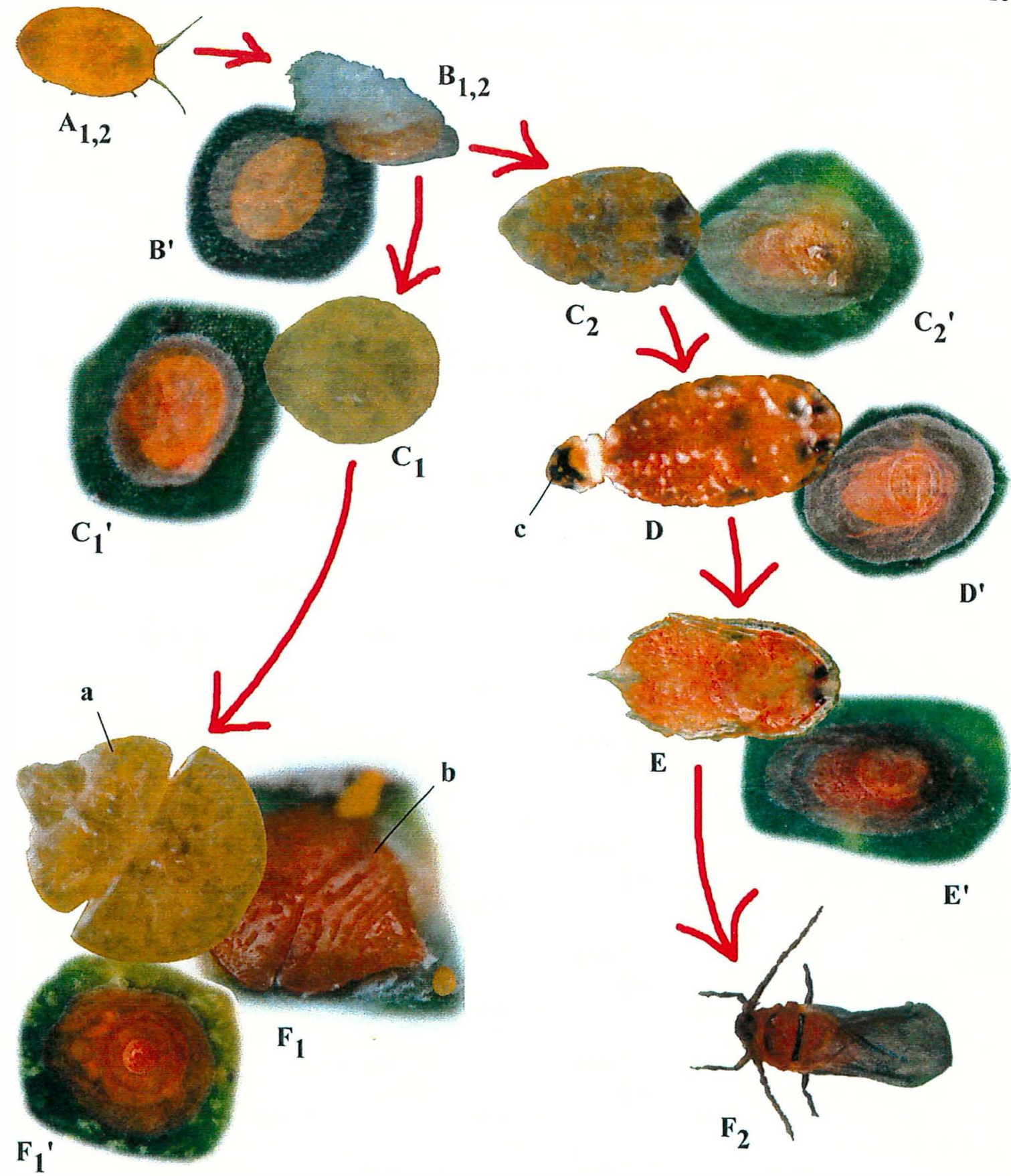

Figura 7. Ciclo de desenvolvimento de fêmeas (1) e machos (2) e carapaças (') de $S$. articulatus. A - ninfa 1 móvel; B - ninfa 1 séssil; C - ninfa 2; D - "prépupa" (c - exúvia); E - "pupa" e; F - adulto (a - jovem; b - maduro sexualmente). 
Devido ao fato deste inseto ser recoberto por uma carapaça dorsal, todas as mudanças de ínstares não são visíveis externamente, porém, é possível reconhecê-las pela forma e tamanho da carapaça. As fêmeas apresentam a carapaça constituída por bandas circulares, que correspondem aos períodos de crescimento das ninfas de primeiro e segundo ínstares e do adulto. Por outro lado, o formato da carapaça nos machos é ovalado (Figura 8).

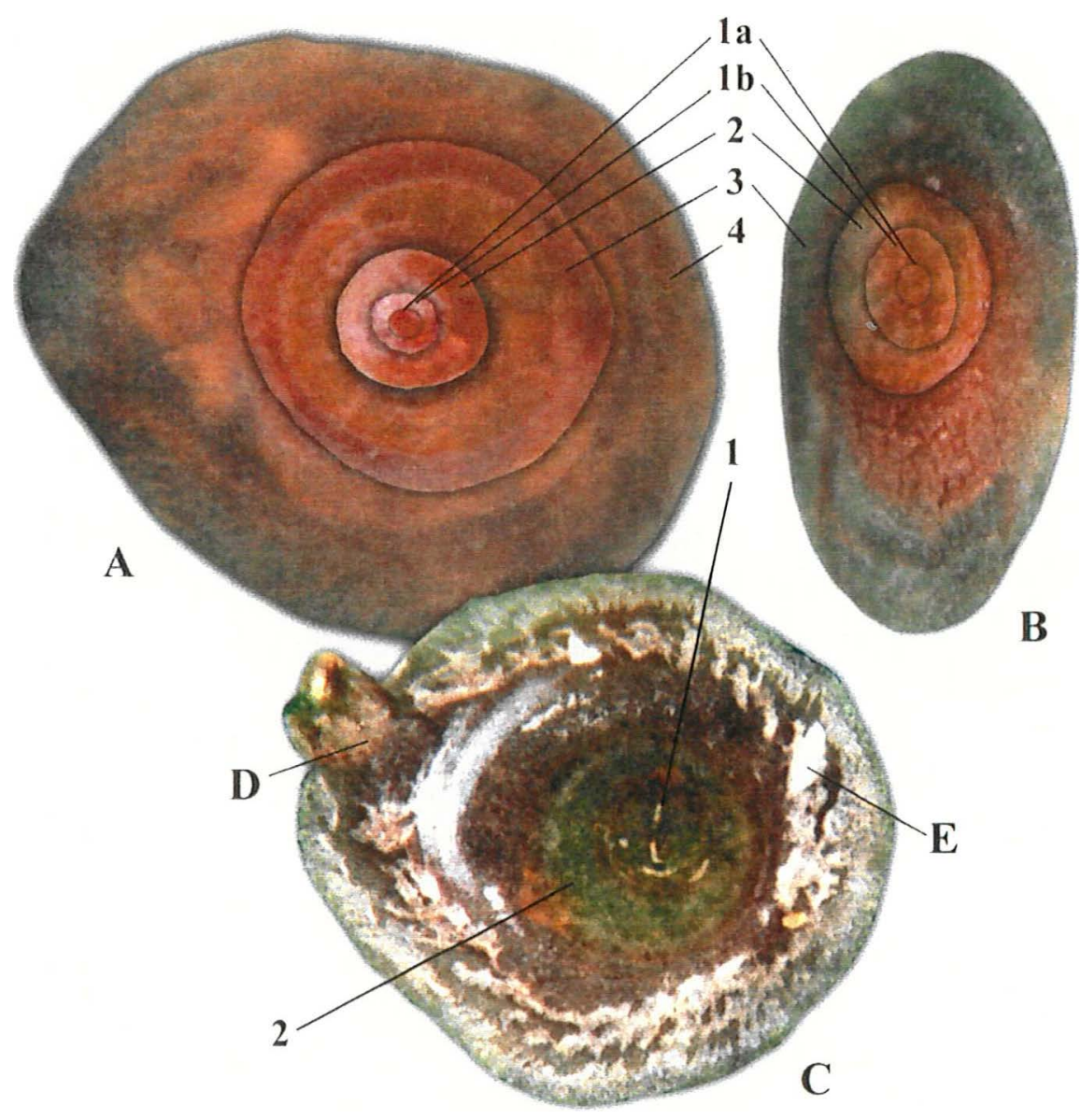

Figura 8. Formato da carapaça dorsal (vista dorsal - A; vista ventral - C; abertura na carapaça - D) da fềmea e do macho (B) de $S$. articulatus, e bandas circulares das mesmas, representando os períodos de crescimento das ninfas de primeiro (la - carapaça branca; lb - carapaça amarela) e segundo (2) ínstares e do adulto (3). E - secreção filamentosa para fixação na folha. 
As características do ínstares, observados na presente pesquisa, são as seguintes:

Primeiro ínstar (ninfa 1) (comum para fêmeas e machos): o primeiro instar é constituído de duas fases, uma móvel (Figura 7A) e a outra séssil (Figura 7B).

- A fase móvel (migrante): possui corpo ovalado, de cor amarela (Figura 7A) e mede $0,22 \mathrm{~mm}$ de comprimento e $0,17 \mathrm{~mm}$ de largura. (Tabela 1 ).

As ninfas móveis, tão logo saiam da carapaça materna, buscam um local adequado para fixação. Elas podem caminhar durante uma hora ou até por 48 horas segundo a temperatura. As ninfas procuram brotações e folhas novas, fixando-se ao longo das nervuras central e secundárias, em ambas as superficies da folha, principalmente na face adaxial. No fruto, elas fixam-se nas depressões da casca. Alguns indivíduos tendem a permanecer na mesma folha, fixando-se ao redor da carapaça materna e de outras cochonilhas adultas, formando colônias.

- A segunda fase (séssil): que apresenta as dimensões de 0,32 mm de comprimento e $0,24 \mathrm{~mm}$ de largura (Tabela 1), compreende duas etapas:

a) a primeira inicia-se com a inserção das peças bucais no hospedeiro. Algumas horas após a fixação, elas começam a produzir uma secreção filamentosa de aspecto cotonoso, originando uma carapaça branca, de formato cônico (Figuras $7 \mathrm{~B}_{1} \mathrm{e}$ $\left.8 \mathrm{~A}_{1,2 \mathrm{a}}\right)$. Na presente pesquisa tem uma duração de um a dois dias, conforme a temperatura. Bartra (1974) afirmou que a duração dessa fase é de um dia.

b) A segunda etapa inicia-se a partir da formação de uma carapaça mais espessa e rígida, formando um halo amarelo ao redor da primeira carapaça. Ao findar o primeiro ínstar, a parte dorsal da exúvia é incorporada à face interna da carapaça (Figuras $7 \mathrm{~B}_{1}$ ' e $8 \mathrm{~A}_{1,2 \mathrm{~b}}$ ), enquanto que a face ventral é fixada à superfície da folha, apenas a área de inserção das peças bucais permanecendo livre, e apresenta cor branca, é cerosa e delicada. 
Tabela 1. Comprimento e largura $(\mathrm{mm})$ das fases imaturas e adultos, de ambos os sexos, de $S$. articulatus criados em laboratório, sobre C. limonia em temperaturas variáveis. UR: $60 \pm 10 \%$; fotofase: 14 horas.

\begin{tabular}{|c|c|c|c|c|c|}
\hline \multicolumn{3}{|c|}{ FÊMEA } & \multicolumn{3}{|c|}{ MACHO } \\
\hline $\begin{array}{l}\text { Fases de de- } \\
\text { senvolvimento }\end{array}$ & $\begin{array}{c}\text { Comprimento } \\
(\mathrm{mm})\end{array}$ & $\begin{array}{l}\text { Largura } \\
(\mathrm{mm})\end{array}$ & $\begin{array}{l}\text { Fases de de- } \\
\text { senvolvimento }\end{array}$ & $\begin{array}{l}\text { Comprimento } \\
(\mathrm{mm})\end{array}$ & $\begin{array}{l}\text { Largura } \\
(\mathrm{mm})\end{array}$ \\
\hline $1^{0}$ instar & & & $1^{0}$ instar & & \\
\hline fase móvel & $0,22 \pm 0,02$ & $0,17 \pm 0,01$ & fase móvel & $0,22 \pm 0,02$ & $0,17 \pm 0,01$ \\
\hline (migrante) & $(0,21-0,24)$ & $(0,16-0,17)$ & (migrante) & $(0,21-0,24)$ & $(0,16-0,17)$ \\
\hline \multirow[t]{2}{*}{ fase fixa } & $0,32 \pm 0,03$ & $0,24 \pm 0,02$ & fase fixa & $0,32 \pm 0,03$ & $0,24 \pm 0,02$ \\
\hline & $(0,30-0,33)$ & $(0,23=0,25)$ & & $(0,30-0,33)$ & $(0,23-0,25)$ \\
\hline $2^{0}$ instar & & & $2^{\circ}$ instar & & \\
\hline \multirow[t]{6}{*}{ (ninfa 2) } & $0,46 \pm 0,03$ & $0,39 \pm 0,03$ & (ninfa 2) & $0,51 \pm 0,08$ & $0,37 \pm 0,04$ \\
\hline & $(0,44=0,47)$ & $(0,37=0,41)$ & & $(0,48=0,55)$ & $(0,35-0,39)$ \\
\hline & & & $3^{\circ}$ ínstar & $0,77 \pm 0,06$ & $0,42 \pm 0,03$ \\
\hline & & & ("pré-pupa") & $(0,75-0,80)$ & $(0,40-0,43)$ \\
\hline & & & $4^{0}$ instar & $0,81 \pm 0,03$ & $0,45 \pm 0,03$ \\
\hline & & & ("pupa") & $(0,75-0,85)$ & $(0,42-0,48)$ \\
\hline \multirow[t]{2}{*}{ Adulta } & $1,22 \pm 0,12$ & $1,05 \pm 0,09$ & Adulta & $0,90 \pm 0,06$ & $0,36 \pm 0,05$ \\
\hline & $(1,16-1,28)$ & $(1,00-1,09)$ & & $(0,84-0,96)$ & $(0,32-0,42)$ \\
\hline
\end{tabular}

Valores entre parênteses expressam o intervalo de variação, ao nível de $5 \%$ de probabilidade.

Tashiro \& Beavers (1968) chamaram as duas etapas da fase séssil de $A$. aurantii de "white cap" e "nipple". Bartra (1974), para S. articulatus utilizou a mesma terminologia citada anteriormente, porém traduzida para o espanhol, isto é, "tapitas blancas", para a primeira etapa e "pezón" ou "tetilla", para a seguinte. Gonzalez (1981) denominou-as de "gorrita blanca" e "gorrita negra", respectivamente, para as duas etapas de Q. perniciosus. 
Segundo ínstar da fêmea (ninfa 2): o corpo é piriforne, de cor amarela (Figura $7 C_{1}$ ), com $0,46 \mathrm{~mm}$ de comprimento e $0,39 \mathrm{~mm}$ de largura (Tabela 1). Dorsalmente, visualiza-se uma nova banda em totno da carapaça do primeiro ínstar (Figuras $7 \mathrm{C}_{1}$ ' e $8 \mathrm{~A}_{2}$ ).

A carapaça torna-se transparente, podendo-se observar o corpo da ninfa. Ao término desse estágio, a exúvia é incorporada da mesma forma descrita anteriortmente, para ninfa de primeiro ínstar. A Figura 8 ilustra as exúvias incorporadas à parte dorsal da carapaça e o ângulo de rotação em relação ao posicionamento das exúvias, tomando como base o pigídio.

Fêmea adulta: apresenta corpo piriforne, de cor amarela, quando jovem, e pigidio marrom (Figura $7 \mathrm{~F}_{1}$ a). Quando madura sexualmente, torna-se laranja (Figura $7 \mathrm{~F}_{1}$ b). Mede 1,22 mm de comprimento e 1,05 mm de largura. (Tabela 1).

A secreção da carapaça inicia-se a partir da última banda do segundo ínstar, expandindo-se ao redor e além do corpo da fêmea (Figura $8 \mathrm{~A}_{3}$ ). $\mathrm{O}$ conjunto, constituído por todas as bandas de secreção, toma o formato circular e convexo. Inicialmente, a carapaça é transparente, tornando-se marrom com a maturação sexual da fêmea. A carapaça mede $2,10 \mathrm{~mm}$ de diâmetro. As fêmeas fecundadas secretam filamentos cerosos de cor branca em toda a periferia da carapaça (com exceção da extremidade posterior), aderindo-a, ventralmente, à superficie da folha (Figura $8 \mathrm{E}$ ). Essa secreção apresenta a função de sustentação das ninfas recém-eclodidas, sendo que a extremidade posterior pernanece livre, constituindo-se na única passagem para as ninfas abandonarem a carapaça materna (Figura 8D).

Conforme Rosen \& Gerson (1985), a carapaça de cochonilhas da família Diaspididae corresponde às distintas fases de desenvolvimento e é formada por secreções de glândulas cerosas. A textura da carapaça, de acordo com o mesmo autor, varia com a espécie de cochonilha e tem a função de proteção contra inimigos naturais.

Gonzalez (1981) observou que as fêmeas do piolho de São-José, $Q$. perniciosus, apresentam as carapaças em formato circular devido à secreção de 
filamentos cerosos enquanto a cochonilha se movimenta, em um ângulo de $360^{\circ}$, ao redor do aparato bucal. Por outro lado, os machos realizam essa rotação em um ângulo inferior a $180^{\circ}$, o que confere à carapaça o típico formato oval.

Segundo ínstar do macho (ninfa 2): ao finalizar o primeiro ínstar, que é similar ao da fêmea, os machos são facilmente distinguidos pelo formato do corpo, que é mais alongado e por apresentar cor amarela escura (Figura $7 \mathrm{C}_{2}$ ). Medem $0,51 \mathrm{~mm}$ de comprimento e $0,37 \mathrm{~mm}$ de largura (Tabela 1). Na cabeça, evidenciam-se duas manchas de cor preta que correspondem aos ocelos (Figura $7 \mathrm{C}_{2}$ ). A secreção glandular é produzida pela última vez, sendo a carapaça de mesmo tamanho nos ínstares seguintes (Figuras $7 \mathrm{C}_{2}$ ' e $8 \mathrm{~B}_{2}$ ). As dimensões da carapaça são $1,32 \mathrm{~mm}$ de comprimento e $1,0 \mathrm{~mm}$ de largura. Diferente das fêmeas, a exúvia é eliminada pela extremidade posterior da carapaça ao findar esse estágio (Figura $7 \mathrm{D}_{\mathrm{c}}$ ). De maneira similar às fêmeas, os machos também secretam filamentos cerosos de cor branca, na parte ventral da carapaça, aderindo ao hospedeiro e auxiliando na fixação e sustentação da forma pupóide. Esses filamentos são produzidos em toda a periferia da carapaça, com exceção da extremidade posterior, a qual permanece livre para a liberação das exúvias.

Terceiro ínstar do macho ("pré-pupa"): o corpo é ovalado, de coloração alaranjada (Figura 7D), medindo $0,77 \mathrm{~mm}$ de comprimento e $0,42 \mathrm{~mm}$ de largura (Tabela 1). Nesse estágio, ocorrem mudanças acentuadas, como a diferenciação da cabeça, definição dos ocelos, a formação de esboços das antenas, pernas e asas e alongamento do abdômen (Figura 7D). Finalizando esse ínstar, o processo de eliminação da exúvia se repete. $\mathrm{Na}$ fase de pré-pupa, ocorre o atrofiamento do aparato bucal e, como conseqüência, $\mathrm{o}$ inseto não se alimenta nos ínstares posteriores.

Quarto ínstar do macho ("pupa"): o corpo é ovalado, alaranjado (Figura 7E), medindo $0,81 \mathrm{~mm}$ de comprimento e $0,45 \mathrm{~mm}$ de largura (Tabela 1). Nesse instar, as antenas, asas e pertras estão mais desenvolvidas. Obsetva-se a presença dos 
ocelos, segmentação no abdômen, com desenvolvimento do estilete copulador (Figura 7E). Como no ínstar anterior, a exúvia é eliminada ao término da fase de pupa.

Macho adulto: $o$ corpo é frágil, de coloração avermelhada (Figura $7 \mathrm{~F}_{2}$ ), medindo $0,90 \mathrm{~mm}$ de comprimento e $0,36 \mathrm{~mm}$ de largura (Tabela 1 ) e envergadura de $1,53 \mathrm{~mm}$. Apresenta um par de longas antenas e um par de asas transparentes, sendo o segundo par modificado em balancins ou halteres. O estilete copulador é longo, possibilitando sua introdução por debaixo da carapaça da fềmea, para a cópula (Figura $\left.7 F_{2}\right)$.

O macho abandona a carapaça após a emergência, podendo á permanecer por mais ou menos tempo dependendo da temperatura (item 4.2), estando apto à fertilização das fềmeas.

Ao atingir a fase adulta, os machos podem permanecer abrigados na carapaça por um a dois dias, se a temperatura for inferior a $18^{\circ} \mathrm{C}$. Em temperaturas superiores, sua atividade é normal, isto é, abandonam a carapaça algumas horas após a ecdise, podendo voar ou caminhar em busca da fêmea.

Gonzalez (1981) observou que os adultos machos de Q. perniciosus são capazes de sobreviver por dois a três dias protegidos na carapaça e que o limiar de temperatura é entre 16 e $17^{\circ} \mathrm{C}$. Em temperaturas inferiores, os insetos podem abandonar a carapaça, porém não voam, somente caminham.

Reprodução: não foi possível observar a presença de ovos, conforme relatado por Bartra (1974), que determinou um período de incubação de alguns minutos. As ninfas recém-eclodidas abandonam a carapaça materna e procuram um local adequado para fixação. No entanto, à temperatura de $18^{\circ} \mathrm{C}$ e umidade de $30 \%$, as ninfas permaneceram abrigadas na carapaça materna, sendo que alguns indivíduos não chegaram a abandoná-la, vindo a morrer. Beingolea (1969) observou um número elevado de fêmeas adultas contendo, no interior da carapaça, toda a progênie morta. $\mathrm{O}$ autor atribuiu essa alta mortalidade ao fato da carapaça estar muito aderida à folha, 
formando um ambiente hermeticamente fechado, não possibilitando a saída das ninfas também pela inferioridade genética desses individuos. Este autor não relacionou este fato com a temperatura e umidade.

Segundo Beingolea (1969) e Bartra (1974), essa cochonilha não se reproduz por partenogênese, assim como observada na presente pesquisa.

\subsection{Temperatura}

\subsubsection{Influência da temperatura nas fases de desenvolvimento}

\subsubsection{Fases imaturas}

Primeiro ínstar (ninfa 1) (comum para fêmeas e machos): a duração média do desenvolvimento de fêmeas e machos foi afetada significativamente pelas temperaturas. Tanto para machos como fêmeas, não houve desenvolvimento a $32^{\circ} \mathrm{C}$ (Tabelas 2 e 3 ).

Este período, para fêmeas, foi inversamente correlacionado com 0 incremento térmico, variando de $11,7\left(30^{\circ} \mathrm{C}\right)$ a 37,5 dias $\left(18^{\circ} \mathrm{C}\right)$ (Tabela 2). Para os machos a mesma tendência foi seguida, com uma variação de $11,1\left(30^{\circ} \mathrm{C}\right)$ a 35,4 dias $\left(18^{\circ} \mathrm{C}\right)$. Bartra $(1974)$ obteve 17 dias na faixa de 24 a $27^{\circ} \mathrm{C}$ e de 28 dias à temperatura de 17 a $20^{\circ} \mathrm{C}$, tanto para machos como para fêmeas.

A viabilidade das ninfas móveis (fềmeas e machos) foi afetada significativamente pelas temperaturas, variando de $61 \%\left(18^{\circ} \mathrm{C}\right)$. a $73 \%\left(30^{\circ} \mathrm{C}\right)$ (Tabelas 4 e 5). As temperaturas de 25 e $28^{\circ} \mathrm{C}$ proporcionaram as mais altas viabilidades $(79,5 \%$ e 78,5\%, respectivamente) (Tabela 4). Com relação às ninfas sésseis, não foi constatada diferença estatística para a viabilidade entre as temperaturas estudadas, para os machos (Tabela 5). Já para as fêmeas, as temperaturas afetaram significativamente a viabilidade, sendo que o valor mais alto $(54,7 \%)$ foi registrada para $20^{\circ} \mathrm{C}$. Os resultados nas demais 
temperaturas foram muito próximos aos obtidos a $20^{\circ} \mathrm{C}$, somente existindo diferenças significativas à 25 e $28^{\circ} \mathrm{C}$. Em geral, ocorreu uma alta mortalidade nesta fase de desenvolvimento (Tabela 4).

Tabela 2. Duração (dias) das fases imaturas e do ciclo total ( fase móvel - adulto) de fèmeas de $S$. articulatus sobre mudas de C. limonia em diferentes temperaturas. UR: $60 \pm 10 \%$; fotofase: 14 horas.

\begin{tabular}{|c|c|c|c|}
\hline $\begin{array}{l}\text { Temperatura } \\
\left({ }^{0} \mathrm{C}\right)\end{array}$ & $\begin{array}{c}1^{\mathrm{o}} \text { instar } \\
\text { (fase móvel }+ \text { fase fixa) } \\
\text { (ninfa 1) }\end{array}$ & $\begin{array}{l}2^{\mathrm{o}} \text { instar } \\
\text { (ninfa 2) }\end{array}$ & Ciclo total \\
\hline 18 & $\begin{array}{c}37,53 \pm 1,66 a \\
(37-38)\end{array}$ & $\begin{array}{c}26,26 \pm 1,40 \mathrm{a} \\
(25-27)\end{array}$ & $\begin{array}{c}63,94 \pm 2,01 a \\
(63-65)\end{array}$ \\
\hline 20 & $\begin{array}{c}34,14 \pm 0,85 b \\
(33-35)\end{array}$ & $\begin{array}{c}26,42 \pm 0,95 \mathrm{a} \\
\quad(26-27)\end{array}$ & $\begin{array}{c}60,68 \pm 0,98 b \\
(60-61)\end{array}$ \\
\hline 22 & $\begin{array}{c}20,92 \pm 1,46 c \\
\quad(20-21)\end{array}$ & $\begin{array}{c}24,56 \pm 1,35 b \\
\quad(24-25)\end{array}$ & $\begin{array}{c}45,28 \pm 1,87 c \\
(45-46)\end{array}$ \\
\hline 25 & $\begin{array}{l}13,55 \pm 0,75 d \\
(13-14)\end{array}$ & $\begin{array}{c}16,17 \pm 0,86 d \\
(15-16)\end{array}$ & $\begin{array}{c}29,94 \pm 1,02 \mathrm{e} \\
(29-30)\end{array}$ \\
\hline 28 & $\begin{array}{l}12,46 \pm 0,68 \mathrm{e} \\
\quad(12-13)\end{array}$ & $\begin{array}{c}15,70 \pm 0,86 \mathrm{e} \\
(15-16)\end{array}$ & $\begin{array}{c}28,01 \pm 1,29 \mathrm{f} \\
(27-28)\end{array}$ \\
\hline 30 & $\begin{array}{l}11,71 \pm 1,28 \mathrm{f} \\
(11-12)\end{array}$ & $\begin{array}{c}19,48 \pm 1,28 c \\
(19-20)\end{array}$ & $\begin{array}{c}31,33 \pm 1,24 d \\
(31-32)\end{array}$ \\
\hline $32^{*}$ & - & - & - \\
\hline
\end{tabular}

Médias seguidas de letras diferentes, na vertical, diferem estatisticamente entre si, pelo teste de Duncan, ao nivel de $5 \%$ de probabilidade;

Valores entre parênteses expressam o intervalo de variação, ao nivel de $5 \%$ de probabilidade;

*Não houve desenvolvimento. 
Tabela 3. Duração (dias) das fases imaturas e do ciclo total (fase móvel - adulto) de machos de $S$. articulatus sobre mudas de C. limonia em diferentes temperaturas. UR: $60 \pm 10 \%$; fotofase: 14 horas.

\begin{tabular}{|c|c|c|c|c|c|}
\hline $\begin{array}{c}\text { Temperatura } \\
\left({ }^{\circ} \mathrm{C}\right)\end{array}$ & $\begin{array}{c}1^{0} \text { ínstar } \\
\text { (fases móvel } \\
+ \text { fase fixa) } \\
\text { (ninfa 1) }\end{array}$ & $\begin{array}{l}2^{\circ} \text { ínstar } \\
\text { (ninfa } 2)\end{array}$ & $\begin{array}{c}3^{9} \text { ínstar } \\
\text { ("pré-pupa") }\end{array}$ & $\begin{array}{l}4^{\circ} \text { ínstar } \\
\text { ("pupa") }\end{array}$ & $\begin{array}{l}\text { Ciclo } \\
\text { total }\end{array}$ \\
\hline 18 & $\begin{array}{c}35,37 \pm 1,12 \mathrm{a} \\
(35-36)\end{array}$ & $\begin{array}{c}15,08 \pm 1,44 b \\
(14-15)\end{array}$ & $\begin{array}{c}5,35 \pm 0,89 b \\
(5-6)\end{array}$ & $\begin{array}{c}6,31 \pm 0,90 a \\
(6-7)\end{array}$ & $\begin{array}{c}62,04 \pm 1,96 a \\
(61-63)\end{array}$ \\
\hline 20 & $\begin{array}{c}32,79 \pm 0,89 b \\
(32-33)\end{array}$ & $\begin{array}{c}15,58 \pm 0,87 \mathrm{a} \\
(15-16)\end{array}$ & $\begin{array}{c}5,86 \pm 0,77 a \\
(5-6)\end{array}$ & $\begin{array}{c}5,44 \pm 0,50 b \\
(5-6)\end{array}$ & $\begin{array}{c}59,36 \pm 1,06 \mathrm{~b} \\
(59-60)\end{array}$ \\
\hline 22 & $\begin{array}{c}20,17 \pm 1,18 c \\
(19-21)\end{array}$ & $\begin{array}{c}15,24 \pm 0,85 a b \\
(15-16)\end{array}$ & $\begin{array}{c}3,73 \pm 0,48 c \\
(3-4)\end{array}$ & $\begin{array}{c}4,08 \pm 0,69 c \\
(3-4)\end{array}$ & $\begin{array}{c}43,04 \pm 1,24 \mathrm{c} \\
(42-44)\end{array}$ \\
\hline 25 & $\begin{array}{c}12,36 \pm 0,68 d \\
(12-13)\end{array}$ & $\begin{array}{c}9,71 \pm 0,77 d \\
(9-10)\end{array}$ & $\begin{array}{c}3,29 \pm 0,45 d \\
(3-4)\end{array}$ & $\begin{array}{c}3,93 \pm 0,60 \mathrm{~cd} \\
(3-4)\end{array}$ & $\begin{array}{c}29,01 \pm 1,38 d \\
(28-29)\end{array}$ \\
\hline 28 & $\begin{array}{c}11,82 \pm 0,99 \mathrm{e} \\
(11-12)\end{array}$ & $\begin{array}{c}7,69 \pm 0,72 \mathrm{e} \\
(7-8)\end{array}$ & $\begin{array}{c}3,14 \pm 0,62 d \\
(3-4)\end{array}$ & $\begin{array}{c}3,67 \pm 0,61 \mathrm{de} \\
(3-4)\end{array}$ & $\begin{array}{c}26,03 \pm 1,10 \mathrm{e} \\
(25-26)\end{array}$ \\
\hline 30 & $\begin{array}{c}11,08 \pm 1,00 \mathrm{f} \\
(10-11)\end{array}$ & $\begin{array}{c}11,88 \pm 0,93 c \\
(11-12)\end{array}$ & $\begin{array}{c}3,57 \pm 0,56 c \\
(3-4)\end{array}$ & $\begin{array}{c}3,54 \pm 0,75 \text { e } \\
(3-4)\end{array}$ & $\begin{array}{c}29,47 \pm 1,46 d \\
(29-30)\end{array}$ \\
\hline $32^{*}$ & - & - & - & - & $=$ \\
\hline
\end{tabular}

Médias seguidas de letras diferentes, na vertical, diferem estatisticamente entre si, pelo teste de Duncan, ao nivel de $5 \%$ de probabilidade;

Valores entre parênteses expressam o intervalo de variação, ao nivel de $5 \%$ de probabilidade;

*Não houve desenvolvimento.

Beingolea (1969) observou 35\% de mortalidade nesse ínstar, comentando que a maior mortalidade do inseto ocorre nesse período, corroborando a afirmação de Tashiro \& Beavers (1968), para A. aurantii, de que a mortalidade da fase móvel é a mais elevada, sendo realmente, a mais suscetível do ciclo do inseto. Conforme Bartra (1974), a mortalidade é de $18 \%$ em laboratório e de $27 \%$ no campo para $S$. articulatus. 
Provavelmente, nesta fase móvel, muitos indivíduos não conseguem se estabelecer na planta hospedeira e também muitos se perdem na planta. Em condições de campo, este problema se agrava, pois eles podem ser arrastados pelo vento, predados ou ainda parasitados.

Tabela 4. Viabilidade (\%) da fase móvel (fixação) e das fases imaturas de fêmeas de S. articulatus sobre mudas de C. limonia em diferentes temperaturas. UR: 60 $\pm 10 \%$; fotofase: 14 horas.

\begin{tabular}{|c|c|c|c|c|}
\hline \multirow{3}{*}{$\begin{array}{c}\text { Temperatura } \\
\left({ }^{\circ} \mathrm{C}\right)\end{array}$} & \multirow{3}{*}{$\mathrm{n}^{* *}$} & \multicolumn{3}{|c|}{ VIABILIDADE (\%) } \\
\hline & & \multicolumn{2}{|l|}{$1^{\circ}$ instar } & \multirow{2}{*}{$\begin{array}{l}2^{\circ} \text { instar } \\
\text { (ninfa 2) }\end{array}$} \\
\hline & & (ninfas móveis - fixação) ${ }^{* * *}$ & (ninfas fixas) & \\
\hline 18 & 50 & $61,00 \pm 2,58 \mathrm{c}$ & $45,86 \pm 9,99 a b$ & $92,93 \pm 4,99 a b$ \\
\hline 20 & 50 & $58,50 \pm 1,91 \mathrm{c}$ & $54,74 \pm 5,26 \mathrm{a}$ & $91,08 \pm 10,15 a b$ \\
\hline 22 & 50 & $59,50 \pm 1,91 \mathrm{c}$ & $46,12 \pm 8,10 a b$ & $81,23 \pm 13,70 b$ \\
\hline 25 & 50 & $79,50 \pm 3,41 \mathrm{a}$ & $43,36 \pm 4,81 b$ & $95,79 \pm 2,84 \mathrm{a}$ \\
\hline 28 & 50 & $78,50 \pm 3,78 a$ & $42,64 \pm 2,75 b$ & $91,21 \pm 5,27 \mathrm{ab}$ \\
\hline 30 & 50 & $73,00 \pm 3,46 b$ & $47,51 \pm 7,96 \mathrm{ab}$ & $93,61 \pm 9,44 \mathrm{ab}$ \\
\hline $32^{*}$ & - & $=$ & - & - \\
\hline
\end{tabular}

Médias seguidas de letras diferentes, na vertical, diferem estatisticamente entre si, pelo teste de Duncan, ao nivel de $5 \%$ de probabilidade;

*Não houve desenvolvimento;

**Número de ninfas móveis analisadas.

***Não há possibilidade de separação de sexós nessa fase de desenvolvimento da cochonilha;

Segundo ínstar da fêmea (ninfa 2): a duração média do desenvolvimento das ninfas de $2^{\circ}$ ínstar foi também afetada significativamente pelas temperaturas. Entre as temperaturas de 18 e $20^{\circ} \mathrm{C}$, não foi constatada diferença, sendo a duração de 26 dias. A partir de $22^{\circ} \mathrm{C}$, os valores para duração foram decrescentes com a elevação térmica, até $28^{\circ} \mathrm{C}$. A $30^{\circ} \mathrm{C}$, este valor voltou a crescer, mostrando uma 
inadequação desta temperatura para este período de desenvolvimento da cochonilha. Em relação ao primeiro ínstar, as durações médias da fase de ninfa II foram superiores na faixa de 22 a $30^{\circ} \mathrm{C}$, ocortendo o inverso a 18 e $20^{\circ} \mathrm{C}$ (Tabela 2).

Bartra (1974) observou, para S. articulatus, duração do segundo ínstar de 15 dias no verão e 19 dias no inverno. O valor obtido no presente trabalho $\left(\right.$ a $28^{\circ} \mathrm{C}$ ) (Tabela 2) está coincidente com aquele apresentado por Bartra (1974), no verão; os valores obtidos à $18^{\circ} \mathrm{C}$ que corresponderiam ao inverno (Tabela 2) (Bartra, 1974), são no entanto, bastante discrepantes.

Marín (1987) registrou, para Q. perniciosus, a média de 11 dias no verão e 22 dias no inverno, para o segundo ínstar.

Com relação à viabilidade dessa fase, observaram-se valores superiores a $80 \%$, em todas as temperaturas, sendo que, a $25^{\circ} \mathrm{C}$, a viabilidade foi de $95 \%$, sem diferir dos valores observados a $18,20,28$ e $30^{\circ} \mathrm{C}$. Por outro lado, a temperatura de $22^{\circ} \mathrm{C}$ porporcionou a menor viabilidade (Tabela 4). A partir da fixação, a mortalidade é menor.

Segundo ínstar do macho (ninfa 2): a duração dessa fase também foi afetada pelas temperaturas, sendo que os maiores valores foram observados a $20,22 \mathrm{e}$ $18^{\circ} \mathrm{C}$ (em média, 15 dias) (Tabela 3). A 25 e $28^{\circ} \mathrm{C}$, as durações foram menores, sendo de 9 e 7 dias, respectivamente. A inadequação da temperatura de $30^{\circ} \mathrm{C}$, mais uma vez ficou demonstrada para S. articulatus (Tabela 3).

Beingolea (1969) e Bartra (1974) não consideraram esse período no ciclo de desenvolvimento de $S$. articulatus. Provavelmente, esses autores não distinguiram as fases imaturas de fêmeas e machos de segundo ínstar, somente separando os machos a partir da fase de "pré-pupa".

Comparando-se o segundo ínstar de fêmeas e machos, verificou-se, em todas as temperaturas, que os valores para duração desse ínstar foram menores para os machos (Tabelas 2 e 3). Valores inferiores para a duração da fase de ninfa II de machos também foram encontrados por Gonzalez (1981) e Marín (1987) para Q. perniciosus. 
A viabilidade dessa fase não foi afetada pela temperatura, sendo, na maioria dos casos, superior a $95 \%$ (Tabela 5).

Tabela 5. Viabilidade (\%) da fase móvel (fixação), das fases imaturas de machos de $S$. articulatus sobre mudas de C. limonia em diferentes temperaturas. UR: $60 \pm$ $10 \%$; fotofase: 14 horas.

\begin{tabular}{|c|c|c|c|c|c|c|}
\hline \multirow{3}{*}{$\begin{array}{c}\text { Tempe- } \\
\text { ratura } \\
\left({ }^{\circ} \mathrm{C}\right)\end{array}$} & \multirow{3}{*}{$\mathrm{n}^{* *}$} & \multicolumn{5}{|c|}{ Viabilidade (\%) } \\
\hline & & \multicolumn{2}{|c|}{$1^{\circ}$ ínstar } & \multirow[b]{2}{*}{$\begin{array}{l}2^{\circ} \text { ínstar } \\
\text { (ninfa 2) }\end{array}$} & \multirow[b]{2}{*}{$\begin{array}{c}3^{0} \text { ínstar } \\
\text { ("pré-pupa") }\end{array}$} & \multirow[b]{2}{*}{$\begin{array}{l}\text { 4 }^{\text {ínstar }} \\
\text { ("pupa") }\end{array}$} \\
\hline & & $\begin{array}{l}\text { (ninfas móveis } \\
\text { - fixação) }\end{array}$ & (ninfas fixas) & & & \\
\hline 18 & 50 & $61,00 \pm 2,58 c$ & $46,81 \pm 9,91 \mathrm{a}$ & $98,07 \pm 3,84 \mathrm{a}$ & $97,22 \pm 5,55 a$ & $94,49 \pm 3,87 \mathrm{a}$ \\
\hline 20 & 50 & $58,50 \pm 1,91 \mathrm{c}$ & $40,93 \pm 6,78 a$ & $100,00 \pm 0,00 \mathrm{a}$ & $95,43 \pm 5,51 \mathrm{a}$ & $94,07 \pm 3,96 \mathrm{a}$ \\
\hline 22 & 50 & $59,50 \pm 1,91 \mathrm{c}$ & $49,73 \pm 7,14 a$ & $89,74 \pm 15,80 a$ & $98,53 \pm 2,94 a$ & $96,35 \pm 4,29 a$ \\
\hline 25 & 50 & $79,50 \pm 3,41 \mathrm{a}$ & $47,83 \pm 2,03 \mathrm{a}$ & $88,06 \pm 20,52 \mathrm{a}$ & $100,00 \pm 0,00 a$ & $93,57 \pm 6,68 \mathrm{a}$ \\
\hline 28 & 50 & $78,50 \pm 3,78 a$ & $48,56 \pm 4,87 a$ & $95,00 \pm 5,77 \mathrm{a}$ & $97,22 \pm 3,21 \mathrm{a}$ & $92,81 \pm 3,05 \mathrm{a}$ \\
\hline 30 & 50 & $73,00 \pm 3,46 b$ & $46,43 \pm 4,69 a$ & $92,55 \pm 3,00 \mathrm{a}$ & $93,99 \pm 8,85 a$ & $87,24 \pm 11,50 a$ \\
\hline $32^{*}$ & - & $=$ & - & - & - & - \\
\hline
\end{tabular}

Médias seguidas de letras diferentes, na vertical, diferem estatisticamente entre si, pelo teste de Duncan, ao nível de $5 \%$ de probabilidade;

*Não houve desenvolvimento;

**Número de ninfas móveis analisadas;

***Não há possibilidade de separação de sexos nessa fase de desenvolvimento da cochonilha;

"Pré-pupa": a duração da fase de "pré-pupa" foi significativamente afetada pela temperatura, sendo os maiores valores registrados a 18 e $20^{\circ} \mathrm{C}$ (em média, 5 a 6 dias) e os menores, a 25 e $28^{\circ} \mathrm{C}$ (em média, 3 dias) (Tabela 3 ).

Bartra (1974) registrou 7 dias, no verão, e 10 dias, no inverno, para a fase de "pré-pupa", valores considerados altos para essa fase, provavelmente em função da flutuação de temperatura e/ou não distinção precisa quanto ao início da fase de "prépupa". Gonzalez (1981) e Marín (1987) consideraram, para Q. perniciesus, 3 a 5 dias 
para esse período. Mais uma vez, houve uma tendência numérica de alongamento da fase a $30^{\circ} \mathrm{C}$ (Tabela 3$)$.

A viabilidade não foi afetada pela temperatura, sendo, em geral, superior a $90 \%$ (Tabela 5).

Bartra (1974) não registrou mortalidade nessa fase, no verão; porém, no inverno, esta foi de $8 \%$.

"Pupa": a duração dessa fase foi influenciada pela temperatura. A maior duração (6 dias) foi obtida a $18^{\circ} \mathrm{C}$. Com o aumento da temperatura, na faixa de 20 a $30^{\circ} \mathrm{C}$, observou-se o decréscimo nos valores para tal duração (Tabela 3).

Bartra (1974) considerou 8 dias, no verão, e 12 dias, no inverno, como média para duração desta fase. A flutuação da temperatura e/ou não separação precisa desta fase da anterior ,pelo autor, pode ter determinado tais variações, conforme citado anteriormente. Marín (1987) registrou o valor de 4 dias, no verão $\left(25^{\circ} \mathrm{C}\right)$, e 9 dias, no inverno $\left(16^{\circ} \mathrm{C}\right)$, para $Q$. perniciosus.

Com relação à viabilidade, não houve diferença estatística entre as temperaturas. Bartra (1974) também registrou baixas mortalidades nesta fase, quais sejam, 3 e $5 \%$, no verão e inverno, respectivamente.

Ciclo de desenvolvimento (ninfa móvel-adulto) das fêmeas e machos: para as fêmeas, observou-se o efeito da temperatura, sendo a duração decrescente na faixa de 18 até $28^{\circ} \mathrm{C}$ de 63 dias para $18^{\circ} \mathrm{C}$, recrescendo a 28 dias à $28^{\circ} \mathrm{C}$.

Nos machos, o ciclo de desenvolvimento seguiu a mesma tendência, sendo de 62 dias a $18^{\circ} \mathrm{C}$, decrescendo para 26 dias a $28^{\circ} \mathrm{C}$, reduzindo-se o ciclo em 36 dias (Tabela 3). A faixa favorável de desenvolvimento, para ambos os sexos, situou-se entre 18 e $28^{\circ} \mathrm{C}$; a partir daí, houve uma tendência de alongamento do ciclo (Tabelas $2 \mathrm{e}$ $3)$.

Bliss et al. (1931), observaram que A. aurantii, apresentou desenvolvimento entre 15 a $23^{\circ} \mathrm{C}$, que corresponde às temperaturas de insetários à 
sombra. Washburn \& Frankie (1985) registraram o desenvolvimento de Pulvinariella mesembryanthemi (Vallot) e Pulvinaria delottoi Targ. em 5 temperaturas $(14,5,17$, $20,5,24,5$ e $27^{\circ} \mathrm{C}$ ). O ciclo do inseto foi mais rápido à $24^{\circ} \mathrm{C}$, em relação à $27^{\circ} \mathrm{C}$, sugerindo serem tais espécies, adaptada a condição de frio.

Em campo, o ataque de $S$. articulatus foi observado na parte baixa das plantas protegidas da insolação direta, como observado por Pinto (1995) e Domecini et al. (1997). A determinação de que o inseto se desenvolveu melhor em 18 e $28^{\circ} \mathrm{C}$, na presente pesquisa, explica os resultados obtidos pelos autores citados, que não relacionaram dados climatológicos com tais observações.

Comparando-se os ciclos de fêmeas e de machos, pôde-se observar que eles apresentaram a mesma tendência, verificando-se uma diferença pequenta ( 1 a 2 dias) nos valores médios (Tabelas 2 e 3), numa dada temperatura. Em alguns casos, o desenvolvimento de ambos os sexos apresentou a mesma duração, observando-se um perfeito sincronismo para a cópula, o que é muito importante, pois os machos apresentam uma longevidade muito pequena em relação às fềmeas.

Tashiro \& Beavers (1968) afirmaram que o desenvolvimento pupal dos machos de $A$. aurantii coincidiu com a segunda e última ecdise das fêmeas, indicando a sincronização para o acasalamento. Gonzalez (1981) comentou que o sincronismo no desenvolvimento de machos e fêmeas foi muito importante para $Q$. perniciosus. Marín (1987), comprovou que ocorreu tal sincronismo no desenvolvimento de machos e fềmeas de $Q$. perniciosus, tanto no verão como no inverno.

Beingolea (1969) referiu, para o ciclo biológico (ninfá móvel - adulto) de S. articulatus, um período de 45 dias para fêmeas e 30 dias para machos. Bartra (1974) afirmou que até a fase adulta, a fềmea apresenta duração de 32 dias (verão) e 47 dias (inverno), enquanto que para o macho, o ciclo foi de 26 dias (verão) e 38 dias (inverno). Os dados obtidos no presente trabalho, na faixa de temperatura de 22 a $28^{\circ} \mathrm{C}$ (Tabelas 2 e 3) coincidem com os valores citados anteriormente por Beingolea (1969) e Bartra (1974), na condição de verão para ambos os sexos, porém, foram diferentes nas temperaturas mais baixas (condição de inverno). Esses autores, não observaram 
sincronismo no desenvolvimento de machos e fêmeas, o que, provavelmente, se deveu, à flutuação nas temperaturas observadas no verão e inverno e/ou à utilização de hospedeiros pouco convencionais ao desenvolvimento da cochonilha, que foram frutos de limão e tubérculos de batata.

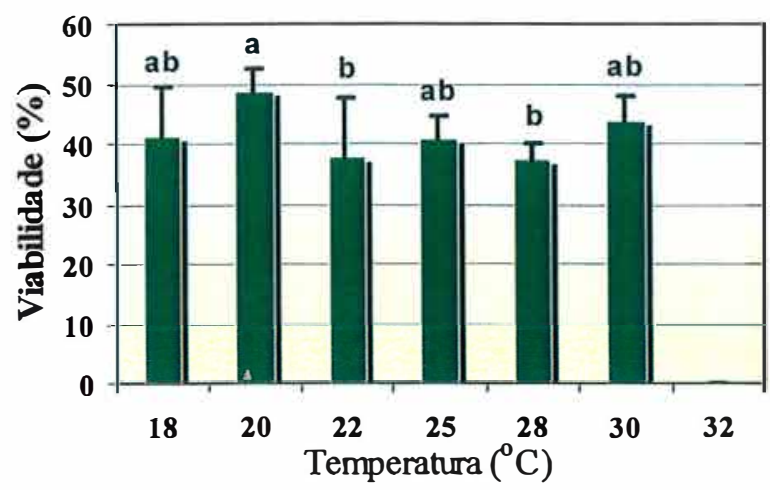

A

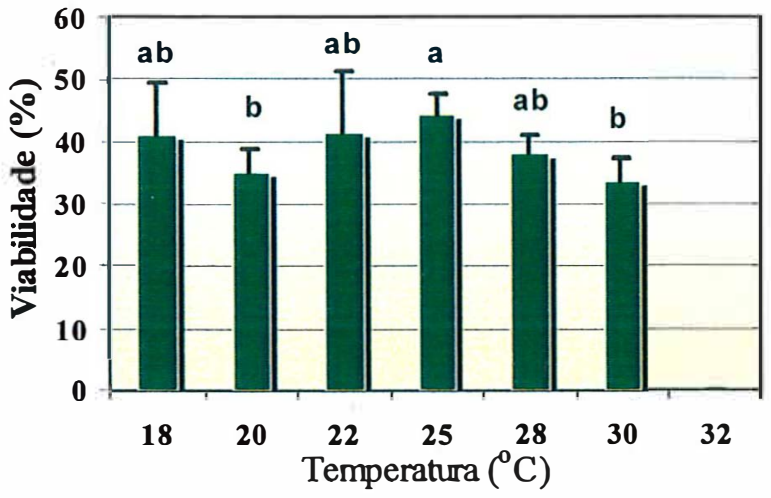

B

Figura 9. Viabilidade (\%) do ciclo total (fase móvel - adulto) de fêmeas (A) e machos (B) de S. articulatus sobre mudas de C. limonia em diferentes temperaturas. UR: $60 \pm 10 \%$; fotofase: 14 horas. Barras seguidas das mesmas letras não diferem significativamente pelo teste de Ducan a 5\%.

Foram constatadas pequenas diferenças na viabilidade, nas diversas temperaturas, tanto para fêmeas como para machos. A mortalidade total, ao final do ciclo, atingiu uma média de 60 \% (Figura 9). É interessante notar que para as fêmeas, embora a duração tenha sido maior a $30^{\circ} \mathrm{C}$ (Tabela 2), não houve correspondência com relação à viabilidade, que foi semelhante aos demais tratamentos, não sendo, portanto, prejudicada nesta condição térmica (Tabela 4).

Beingolea (1969) encontrou $70 \%$ de mortalidade no ciclo total de $S$. articulatus e Bartra (1974) registrou 46 e $73 \%$ de mortalidade no verão e inverno, respectivamente, para esta espécie. 


\subsubsection{Fase adulta}

Período de 'pré-oviposição': este período foi influenciado significativamente pela temperatura. A $18^{\circ} \mathrm{C}$, tal período foi de 56 dias, diminuindo com a elevação térmica, chegando a 16 dias a $28^{\circ} \mathrm{C}$, o que representa uma redução em 30 dias em relação ao valor obtido a $18^{\circ} \mathrm{C}$. Por outro lado, a $30^{\circ} \mathrm{C}$, condição desfavorável à cochonilha (item 4.2.1), S. articulatus, este período foi de 43 dias (Tabela 6).

Beingolea (1969) considerou 45 dias para esse periodo de 'préoviposição' e Bartra (1974) o considerou como sendo de 16 dias, no verão e de 20 dias, no inverno. Conforme mencionado anteriormente, para ninfas de segundo ínstar (fêmeas), os dados obtidos no presente trabalho (Tabela 6) ajustaram-se àqueles citados por Bartra (1974), no verão, porém são discordantes dos registrados no inverno. Marín (1987) obteve, para Q. perniciosus, um período de 'pré-oviposição' de 23 dias no verão e de 42 dias no inverno.

Período de 'oviposição': foi constatada diferença significativa entre as médias, em função da temperatura, para o período de 'oviposição'. A maior duração para esse período registrou-se nas temperaturas de 25 e $28^{\circ} \mathrm{C}$ ( 55 dias). A 18 e $20^{\circ} \mathrm{C}$, foi menor o período de 'oviposição' (32 dias), sem diferir estatisticamente daquele observado a $30^{\circ} \mathrm{C}$ ( 33 dias) A $22^{\circ} \mathrm{C}$, registrou-se uma duração de 42 dias (Tabela 6).

Conforme Beingolea (1969), para essa mesma espécie, o período de 'oviposição' foi de 30 dias. Para Bartra (1974), esse período foi de 60 dias no verão e de 85 dias no inverno, contrariamente aos resultados observados no presente trabalho, no qual as menores durações foram verificadas nas menores temperaturas $\left(18\right.$ e $\left.20^{\circ} \mathrm{C}\right)$. 
Tabela 6. Duração dos períodos de "pré-oviposição", "oviposição" e longevidade de fêmeas e de machos de $S$. articulatus sobre mudas de $C$. limonia em diferentes temperaturas. UR: $60 \pm 10 \%$; fotofase: 14 horas.

\begin{tabular}{ccccc}
\hline \multirow{2}{*}{$\begin{array}{c}\text { Temperatura } \\
\left({ }^{\circ} \mathrm{C}\right)\end{array}$} & "Pré-oviposição" & "Oviposição" & \multicolumn{2}{c}{ Longevidade } \\
\cline { 4 - 5 } (dias) & & fềmea (dias) & macho (horas) \\
\hline 18 & $56,98 \pm 1,86 \mathrm{a}$ & $32,83 \pm 8,47 \mathrm{c}$ & $89,82 \pm 1,78 \mathrm{a}$ & $21,59 \pm 2,50 \mathrm{c}$ \\
& $(56-57)$ & $(29-36)$ & $(88-91)$ & $(21-22)$ \\
20 & $46,20 \pm 1,02 \mathrm{~b}$ & $32,83 \pm 6,78 \mathrm{c}$ & $79,04 \pm 1,87 \mathrm{~b}$ & $21,13 \pm 1,81 \mathrm{c}$ \\
& $(45-47)$ & $(30-35)$ & $(78-80)$ & $(20-22)$ \\
22 & $31,07 \pm 1,14 \mathrm{~d}$ & $42,00 \pm 8,57 \mathrm{~b}$ & $73,07 \pm 0,90 \mathrm{~b}$ & $23,52 \pm 1,16 \mathrm{~b}$ \\
& $(30-31)$ & $(39-45)$ & $(72-74)$ & $(23-24)$ \\
25 & $20,40 \pm 1,50 \mathrm{e}$ & $55,83 \pm 16,19 \mathrm{a}$ & $76,23 \pm 5,85 \mathrm{~b}$ & $37,05 \pm 5,66 \mathrm{a}$ \\
& $(20-21)$ & $(50-62)$ & $(72-80)$ & $(36-38)$ \\
28 & $16,60 \pm 0,94 \mathrm{f}$ & $55,16 \pm 12,35 \mathrm{a}$ & $71,76 \pm 7,31 \mathrm{~b}$ & $36,73 \pm 3,40 \mathrm{a}$ \\
& $(16-17)$ & $(50-60)$ & $(66-77)$ & $(36-38)$ \\
& $43,66 \pm 1,86 \mathrm{c}$ & $33,83 \pm 8,37 \mathrm{c}$ & $77,49 \pm 1,97 \mathrm{~b}$ & $24,54 \pm 3,94 \mathrm{~b}$ \\
& $(43-44)$ & $(31-37)$ & $(76-79)$ & $(23-25)$ \\
\hline
\end{tabular}

Médias seguidas de letras diferentes, na vertical, diferem estatisticamente entre si, pelo teste de Duncan, ao nivel de $5 \%$ de probabilidade;

Valores entre parènteses expressam o intervalo de variação, ao nivel de $5 \%$ de probabilidade.

Tashiro \& Beavers (1968), para A. aurantii, registraram 63 dias para o período de 'oviposição'. Gonzalez (1981) comentou que as espécies ovovivíparas têm capacidade de regular o processo de 'oviposição', restringindo o número de ovos no inverno, retomando à atividade normal de oviposição quando as condições climáticas são favoráveis.

Fecundidade: constatou-se diferença significativa na fecundidade em função da temperatura (Tabela 7). Nas menores temperaturas $\left(18\right.$ e $\left.20^{\circ} \mathrm{C}\right)$, obtiveram-se as mais baixas fecundidades (em torno de 52 ninfas móveis/ fêmea). A $22^{\circ} \mathrm{C}$, foram 
obtidas 88 ninfas, ao passo que a 25 e a $28^{\circ} \mathrm{C}$, verificou-se um incremento na fecundidade da cochonilha pardinha, registrando-se os valores de 135 e 132 ninfas, respectivamente (Tabela 7 e Figura 10 ). A $30^{\circ} \mathrm{C}$, verificou-se um decréscimo em tal fecundidade (59 ninfas), não diferindo estatisticamente dos valores obtidos a 18 e $20^{\circ} \mathrm{C}$.

Tabela 7. Fecundidade de $S$. articulatus criadas sobre mudas de C. limonia em diferentes temperaturas. UR: $60 \pm 10 \%$; fotofase: 14 horas.

\begin{tabular}{ccc}
\hline $\begin{array}{c}\text { Temperatura } \\
\left({ }^{\circ} \mathrm{C}\right)\end{array}$ & $\mathrm{n}^{*}$ & $\begin{array}{c}\text { Fecundidade } \\
\text { (ninfas móveis/fêmea) }\end{array}$ \\
\hline 18 & 30 & $52,67 \pm 12,94 \mathrm{c} \mathrm{(48-57)}$ \\
20 & 30 & $51,30 \pm 12,78 \mathrm{c} \mathrm{(47-56)}$ \\
22 & 30 & $88,00 \pm 24,95 \mathrm{~b}(79-97)$ \\
25 & 30 & $135,40 \pm 46,60$ a $(118-153)$ \\
28 & 30 & $132,00 \pm 43,41$ a $(116-148)$ \\
30 & 30 & $59,37 \pm 18,82 \mathrm{c}(52-66)$
\end{tabular}

Médias seguidas de letras diferentes, na vertical, diferem estatisticamente entre si, pelo teste de Duncan, ao nível de $5 \%$ de probabilidade;

Valores entre parênteses expressam o intervalo de variação, ao nível de $5 \%$ de probabilidade;

*Número de fêmeas analisadas.

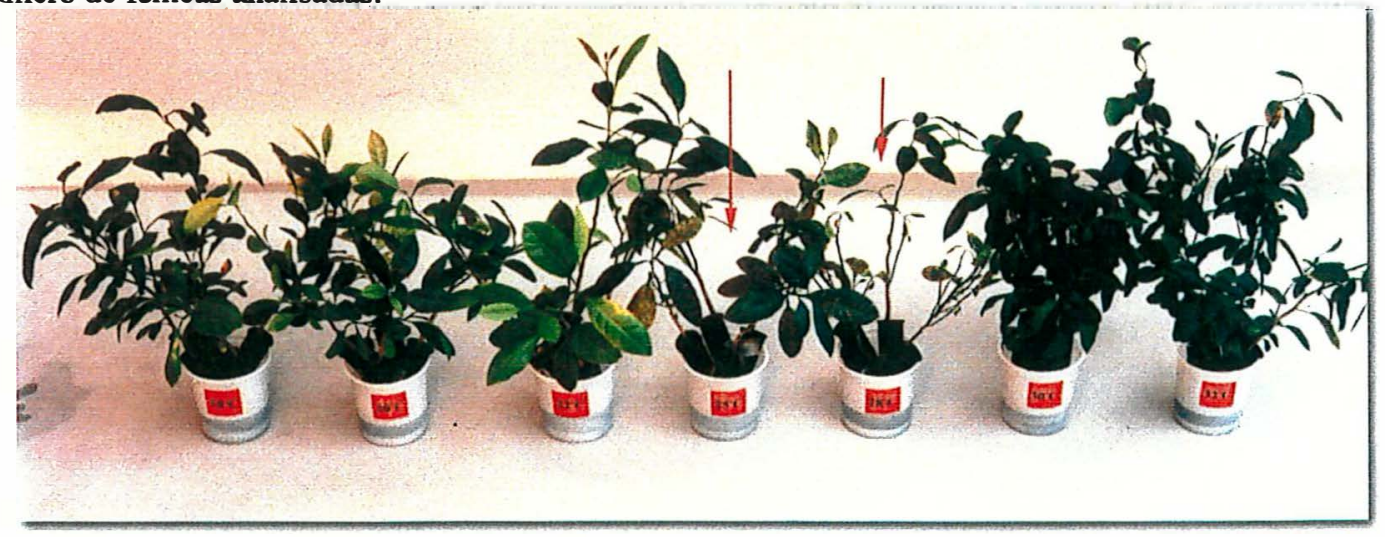

Figura 10. Tratamentos utilizados nos ensaios de diferentes temperaturas, destacando-se a maior desfolha naqueles à 25 e $28^{\circ} \mathrm{C}$. 
Beingolea (1969), para essa mesma espécie, registrou 54 a 122 ninfas móveis/ fêmea. Por outro lado, Bartra (1974) afirmou que a fecundidade é influenciada pelo hospedeiro, ou seja, em frutos de limão, obteve 109 ninfas, em tubérculos de batata, 26 e em Citrullus, 124 ninfas/ fêmea. Na presente pesquisa, em mudas de limão 'Cravo', o valor de ninfas móveis/fêmea, nas melhores condições $\left(25\right.$ e $\left.28^{\circ} \mathrm{C}\right)$ (Tabela 7), foi superior ao relatado por Bartra (1974), nesse mesmo hospedeiro.

Bliss et al. (1931) registraram de 18 a 176 ninfas para $A$. curcuntii, enquanto que, para Tashiro \& Beavers (1968), a fecundidade variou de 102 a 479 ninfas/ fềmea para essa mesma espécie e Marín (1987), para Q. perniciosus, obteve uma fecundidade de 30 a 145 ninfas móveis.

Com relação ao ritmo de 'oviposição', de modo geral, e foi crescente a partir de 15 dias (Figura 11). A 18 e a $20^{\circ} \mathrm{C}$, o ritmo de postura foi menos intenso, decrescendo já a partir de 30 dias (Figura 11). A 22 e a $25^{\circ} \mathrm{C}$, a taxa de 'oviposição' permaneceu elevada até cerca de 50 dias. A $28^{\circ} \mathrm{C}$, o ritmo de postura foi mais intenso, sendo crescente até 60 dias. A $30^{\circ} \mathrm{C}$, verificou-se o decréscimo da taxa de 'oviposição' a partir do $30^{\circ}$ dia, de forma semelhante ao ocorrido a 18 e a $20^{\circ} \mathrm{C}$ (Figura 11).

De acordo com Tashiro \& Beavers (1968), o pico na 'oviposição' de $A$. aurantii ocorreu nas primeiras 5 semanas, registrando-se, no período, mais de $50 \%$ de eclosão das ninfas, com os valores decrescendo posteriormente, mas prolongando-se por 10 a 25 semanas.

Longevidade de fêmeas e machos: a longevidade das fêmeas foi maior na menor temperatura $\left(18^{\circ} \mathrm{C}\right)(89$ dias), devido à menor atividade metabólica do inseto. A partir de $20^{\circ} \mathrm{C}$, não houve diferenças significativas, variando entre 70 e 80 dias (Tabela 6). Os dados obtidos estão de acordo com aqueles verificados por Beingolea (1969), para essa mesma espécie (80 dias).

Para os machos, observou-se uma longevidade efêmera e influenciada pela temperatura. A 18 e a $20^{\circ} \mathrm{C}$, constatou-se a menor longevidade ( 21 horas), a qual 
aumentou com o acréscimo da temperatura até $28^{\circ} \mathrm{C}$ ( 36 horas). A $30^{\circ} \mathrm{C}$, comportou-se da mesma forma que a $22^{\circ} \mathrm{C}$ (viveram ao redor de 24 horas) (Tabela 6).
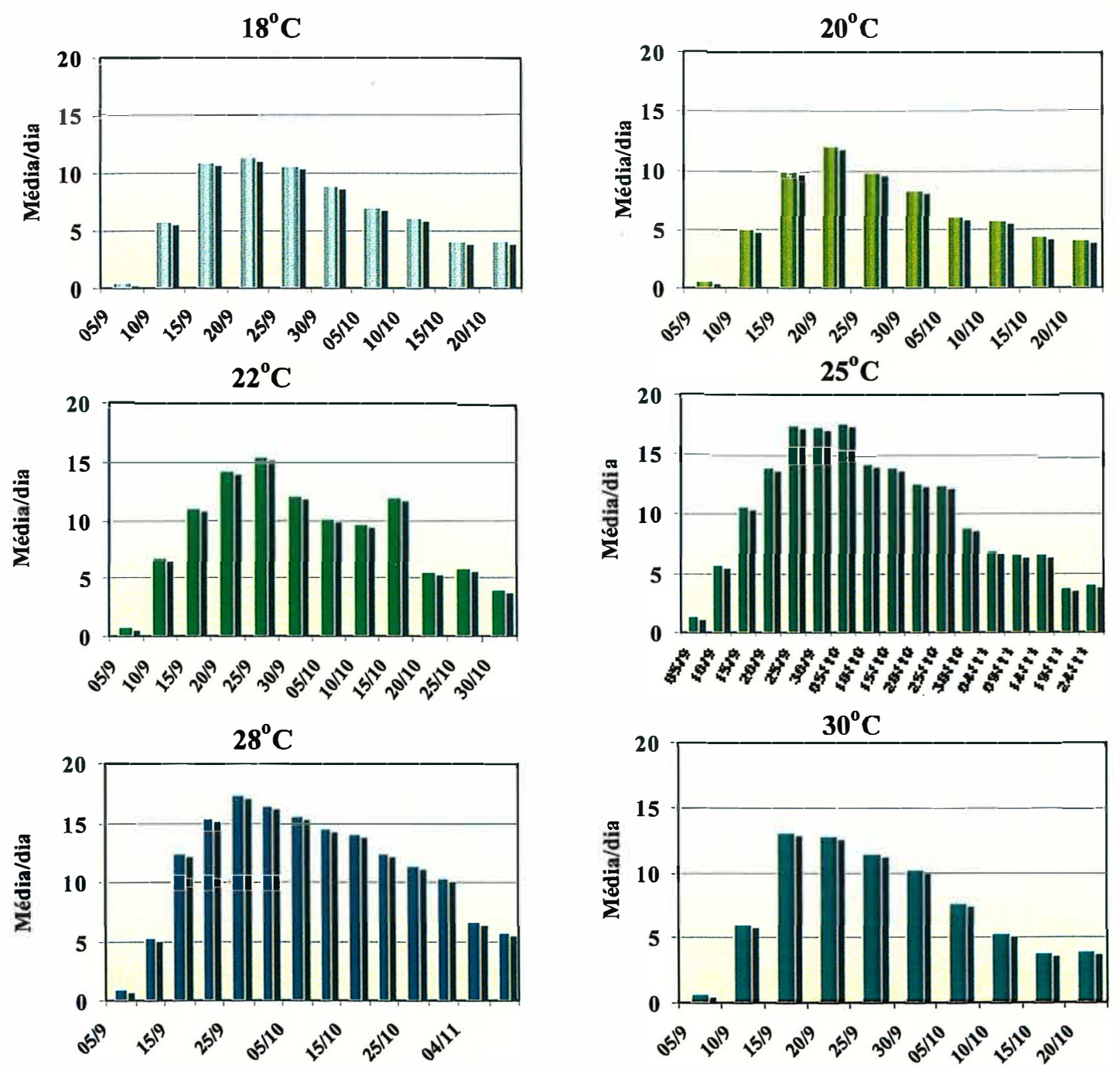

Figura 11. Ritmo de oviposição de S. articulatus em folhas de C. limonia em diferentes temperaturas. UR: $60 \pm 10 \%$; fotofase: 14 horas.

Bartra (1974), para essa mesma espécie, verificou 19 horas para a longevidade dos machos. Para A. aurantii, Quayle (1911) estabeleceu uma longevidade de 1 a 5 dias, porém Tashiro \& Beavers (1968) contestaram-no, registrando a mortalidade dos machos em 6 a 7 horas, alcançando, no máximo, 14 horas de vida. Em 
estudos adicionais, nos quais os machos foram mantidos no escuro, observou-se que alguns deles sobreviveram por 28 horas a $25^{\circ} \mathrm{C}$ e por 42 horas a $10^{\circ} \mathrm{C}$ (Tashiro \& Beavers, 1968).

Ciclo de vida (ninfa móvel-morte do adulto) de fêmeas: o ciclo de vida foi influenciado pela temperatura (Tabela 8 ), verificando-se o maior valor (154 dias) a $18^{\circ} \mathrm{C}$. Com o incremento da temperatura, observou-se a diminuição no ciclo de vida, obtendo-se 99 dias a $28^{\circ} \mathrm{C}$. A $30^{\circ} \mathrm{C}$, embora, numericamente, tenha havido uma tendência de alongamento, este valor não diferiu das médias obtidas a 25 e $28^{\circ} \mathrm{C}$ (Tabela 8).

Tabela 8. Duração do ciclo de vida (fase móvel - morte do adulto) (dias) de fêmeas de S. articulatus sobre mudas de C. limonia em diferentes temperaturas. UR: 60 $\pm 10 \%$; fotofase: 14 horas.

\begin{tabular}{cccc}
\hline $\begin{array}{c}\text { Temperatura } \\
\left({ }^{\circ} \mathrm{C}\right)\end{array}$ & $\begin{array}{c}\text { Ciclo de desenvolvimento } \\
\text { (fase móvel - adulto })\end{array}$ & $\begin{array}{c}\text { Longevidade } \\
\text { (adulto })\end{array}$ & $\begin{array}{c}\text { Ciclo de vida } \\
\text { (fase móvel - morte do adulto) }\end{array}$ \\
\hline 18 & $63,94 \pm 2,01 \mathrm{a}$ & $89,82 \pm 1,78 \mathrm{a}$ & $153,79 \pm 1,76 \mathrm{a}$ \\
$(63-65)$ & $(88-91)$ & $(152-155)$ \\
20 & $60,68 \pm 0,98 \mathrm{~b}$ & $79,04 \pm 1,87 \mathrm{~b}$ & $139,73 \pm 1,77 \mathrm{~b}$ \\
& $(60-61)$ & $(78-80)$ & $(138-141)$ \\
22 & $45,28 \pm 1,87 \mathrm{c}$ & $73,07 \pm 0,90 \mathrm{~b}$ & $118,57 \pm 0,15 \mathrm{c}$ \\
& $(45-46)$ & $(72-74)$ & $(118-119)$ \\
25 & $29,94 \pm 1,02 \mathrm{e}$ & $76,23 \pm 5,85 \mathrm{~b}$ & $106,17 \pm 5,89 \mathrm{~d}$ \\
& $(29-30)$ & $(72-80)$ & $(102-110)$ \\
28 & $28,01 \pm 1,29 \mathrm{f}$ & $71,76 \pm 7,31 \mathrm{~b}$ & $99,77 \pm 7,45 \mathrm{~d}$ \\
& $(27-28)$ & $(66-77)$ & $(94-105)$ \\
30 & $31,33 \pm 1,24 \mathrm{~d}$ & $77,49 \pm 1,97 \mathrm{~b}$ & $108,81 \pm 1,60 \mathrm{~cd}$ \\
& $(31-32)$ & $(76-79)$ & $(108-110)$
\end{tabular}

Médias seguidas de letras diferentes, na vertical, diferem estatisticamente entre si, pelo teste de Duncan, ao nível de $5 \%$ de probabilidade;

Valores entre parênteses expressam o intervalo de variação, ao nivel de $5 \%$ de probabilidade. 
Herrera Aranguena (1964) observou, para $S$. articulatus, ciclo de vida de 132 a 168 dias em temperaturas flutuantes entre 16 a $18^{\circ} \mathrm{C}$, no imverno, e de 58 a 95 dias no verão (temperaturas variáveis de $20 \mathrm{a} 24^{\circ} \mathrm{C}$ ), valores estes próximos àqueles obtidos no presente trabalho (Tabela 8).

Razão sexual: não foi constatada diferença significativa para essa variável, sendo os sexos igualmente afetados pelas temperaturas. A razão sexual, para $S$. articulatus, foi sempre próxima de 0,5 (Tabela 9).

Bartra (1974) considerou a relação sexual de 1:1,5 (machos:fêmeas), para a mesma espécie.

Tabela 9. Relação sexual e razão sexual de S. articulatus em folhas de C. limonia em diferentes temperaturas. UR: $60 \pm 10 \%$; fotofase: 14 horas.

\begin{tabular}{cccc}
\hline $\begin{array}{c}\text { Temperatura } \\
\left({ }^{\circ} \mathrm{C}\right)\end{array}$ & $\mathrm{n}^{*}$ & $\begin{array}{c}\text { Relação } \\
\text { sexual }\end{array}$ & $\begin{array}{c}\text { Razão } \\
\text { sexual }\end{array}$ \\
\hline 18 & 112 & $1,00: 1$ & 0,50 I \\
20 & 112 & $1,33: 1$ & 0,57 I \\
22 & 113 & $0,95: 1$ & 0,49 I \\
25 & 145 & $0,91: 1$ & 0,47 I \\
28 & 143 & $0,88: 1$ & 0,47 I \\
30 & 137 & $1,01: 1$ & 0,50 I
\end{tabular}

Médias seguidas do mesmo algarismo romano, não diferem entre si, pelo teste Qui-quadrado, ao nivel de $5 \%$ de probabilidade.

* Número de adultos.

Sobrevivência: em todas as temperaturas, com exceção de $18^{\circ} \mathrm{C}$ para fêmeas, as curvas de sobrevivência, para ambos os sexos, ajustaram-se ao modelo matemático de Weibull (Figuras 12 e 13) (Sgrillo, 1982), permitindo a estimativa da sobrevivência da espécie em laboratório para programas de criação em pequena, média ou grande escala. 

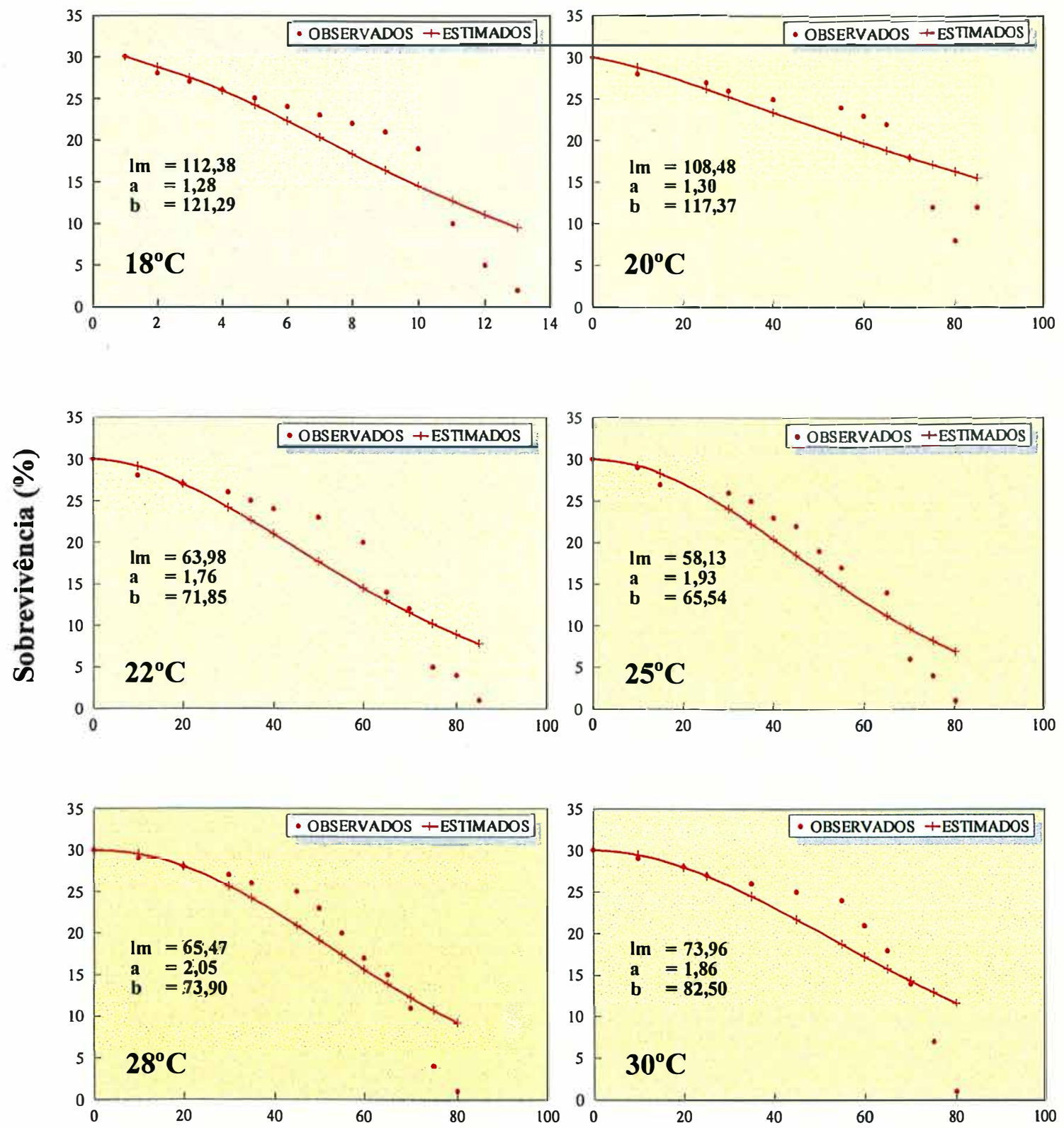

\section{Dias}

Figura 12. Curvas de sobrevivência de Weibull para fêmeas de S. articulatus em folhas de $C$. limonia em diferentes temperaturas. UR: $60 \pm 10 \%$; fotofase: 14 horas. 

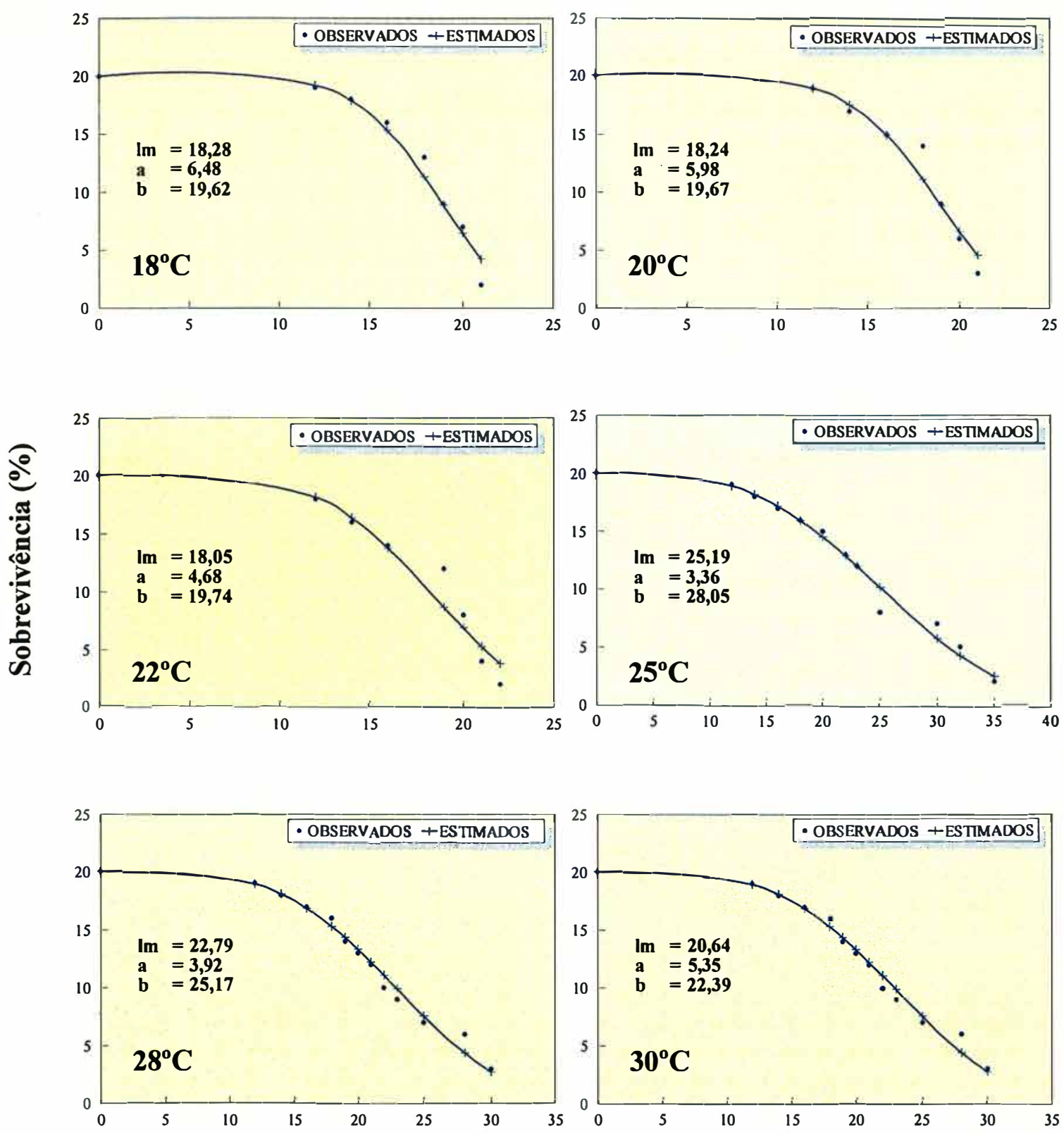

\section{Horas}

Figura 13. Curvas de sobrevivência de Weibull para machos de $S$. articulatus em folhas de C. limonia em diferentes temperaturas. UR: $60 \pm 10 \%$; fotofase: 14 horas. 


\subsubsection{Determinação das exigências térmicas e número anual de gerações de S. articulatus}

A velocidade de desenvolvimento em função da temperatura ajustou-se ao modelo linear obtido através da recíproca da equação da hipérbole (Figura 14) (Haddad \& Parra, 1984). As exigências térmicas foram variáveis dependendo do sexo. Assim, para o desenvolvimento das fềmeas (ninfa móvel-adulto), a temperatura base (limiar térmico inferior de desenvolvimento) foi de $11,87^{\circ} \mathrm{C}$ e a respectiva constante térmica, de 435,17GD, com um coeficiente de determinação de 93,96\%. Para a fase jovem, o limiar térmico inferior de desenvolvimento e a constante térmica foram de $14,08^{\circ} \mathrm{C}$ e $165,74 \mathrm{GD}\left(\mathrm{R}^{2}=94,89 \%\right)$ e $6,80^{\circ} \mathrm{C}$ e $326,36 \mathrm{GD}\left(\mathrm{R}^{2}=86,37 \%\right)$, para ninfa 1 e ninfa 2 , respectivamente.

Por outro lado, a temperatura base para os machos (ninfa móvel- adulto) foi de $12,30^{\circ} \mathrm{C}$ e a respectiva constante térmica de $398,66 \mathrm{GD}\left(\mathrm{R}^{2}=95,58 \%\right)$. Para a fase jovem, a temperatura base e respectiva constante térmica e coeficiente de determinação foram de $14,21^{\circ} \mathrm{C}, 153,30 \mathrm{GD}$ e $93,09 \%$ (ninfa 1 ); $10,22^{\circ} \mathrm{C}, 144,31 \mathrm{GD}$ e $86,82 \%$ (ninfa 2); $6,72^{\circ} \mathrm{C}, 63,30 \mathrm{GD}$ e $84,22 \%$ ('pré-pupa'); $5,25^{\circ} \mathrm{C}, 68,34 \mathrm{GD}$ e $90,09 \%$ ('pupa') (Tabela 10 e Figura 14).

A variação de 36,51GD nas exigências térmicas entre machos e fêmeas, poderá representar, em épocas quentes e úmidas (favoráveis ao desenvolvimento da cochonilha) uma diferença de 2 a 4 dias, que deverão ser levados em conta na previsão de ocorrência da praga.

Com base nas exigências térmicas e nas normais térmicas das cinco regiões citrícolas do Estado de São Paulo consideradas (Tabela 11), o número provável de gerações da praga ao longo do ano, varia de 6 a 10, para os machos e de 6 a 9 , para as fềmeas (Tabela 12). As regiões de Barretos e São José do Rio Preto propiciaram o maior número de gerações anuais de S. articulatus (Tabela 12), por serem regiões mais quentes. As variações são muito grandes entre as regiões, podendo haver diferença de quase quatro gerações por ano, dependendo da região citrícola. Herrera (1964) obteve quatro gerações da praga para a costa central do Peru, com base nos ciclos biológicos 
(ninfa móvel- morte do adulto). Pinto (1995) verificou a ocorrência de quatro gerações de $S$. articulatus na região de Taquaritinga (SP), tomando por base os picos da população ninfal que ocorreram durante $\mathrm{o}$ ano.

Tabela 10. Temperatura base $(\mathrm{Tb})$, constante térmica $(\mathrm{k})$ e coeficiente de determinação $\left(\mathrm{R}^{2}\right)$ de $S$. articulatus (fêmea e macho) baseando-se no desenvolvimento em C. limonia.

Fases de desenvolvimento

Temperatura base $\left({ }^{\circ} \mathrm{C}\right)$

Constante térmica (GD)
Coeficiente de determinação $\left(\% R^{2}\right)$

Fêmea:

$1^{\mathrm{o}}$ Ínstar: (ninfa 1)
$2^{\mathrm{o}}$ Ínstar: (ninfa 2)

Ciclo total

Macho:
$1^{0}$ Ínstar: (ninfa 1$)$

$2^{\circ}$ Ínstar: (ninfa 2)

3 o Ínstar: ("pré-pupa")

4ํㅡnstar: ("pupa")

$$
14,08
$$$$
6,80
$$

165,74

326,36

435,17

153,30

144,31

63,30

68,34

5,25

12,30

398,66

68,34

94,89

86,37

93,96

93,09

86,82

84,22

90,09

Ciclo total

95,58

\subsubsection{Tabela de vida de fertilidade}

A taxa líquida de reprodução $\left(\mathrm{R}_{\mathrm{o}}\right)$ de $S$. articulatus variou de $11,95\left(18^{\circ} \mathrm{C}\right)$ a $29,21\left(25^{\circ} \mathrm{C}\right)$, sendo crescente neste intervalo de temperatura. A $28^{\circ} \mathrm{C}$, a taxa líquida de reprodução diminuiu para 23,81 , atingindo 13,94 a $30^{\circ} \mathrm{C}$. Baseando-se, portanto, no número de vezes que a população aumenta a cada geração, as temperaturas mais favoráveis ao desenvolvimento do inseto foram as de 25 e $28^{\circ} \mathrm{C}$ (Tabela 13). 


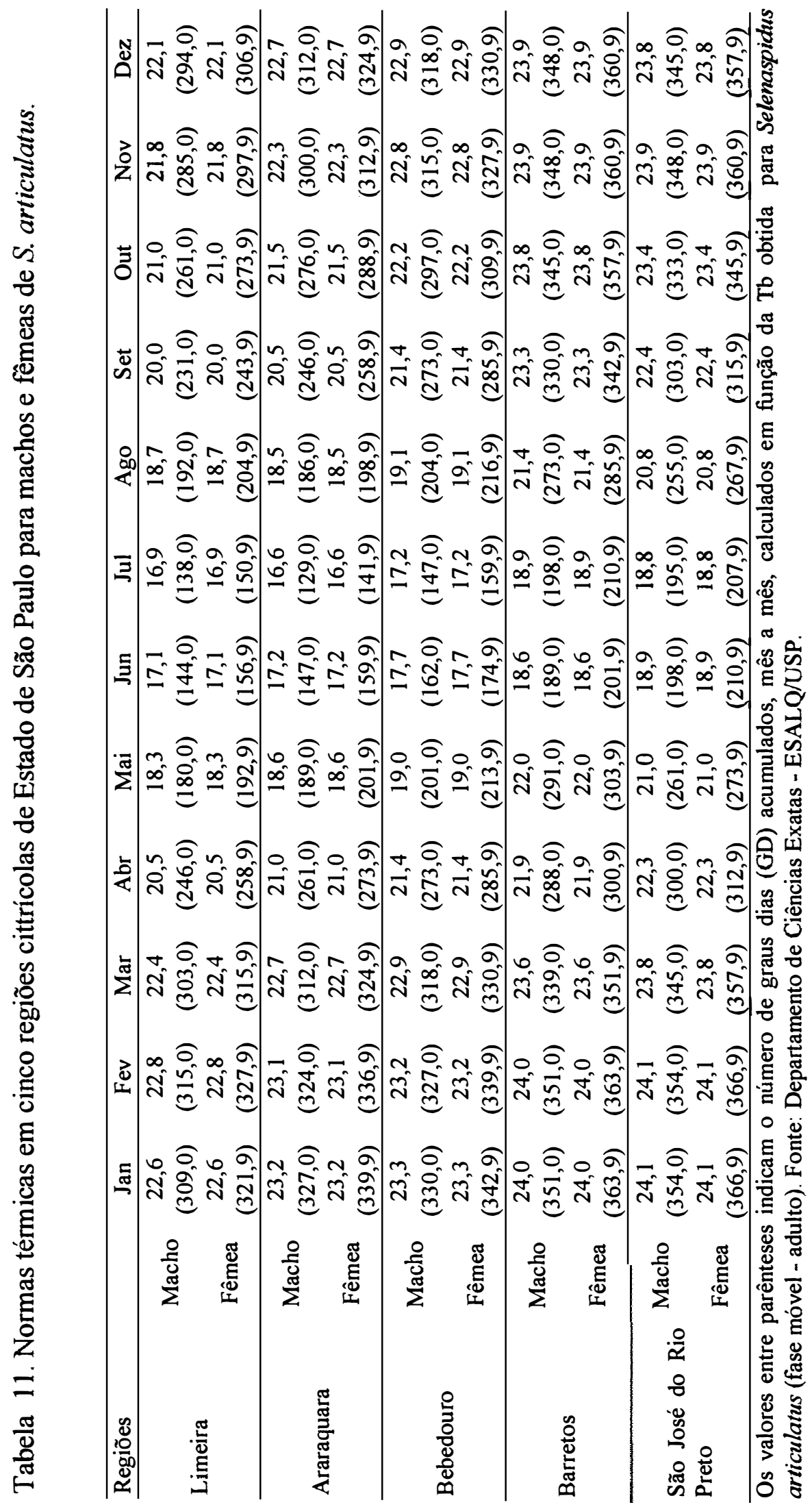



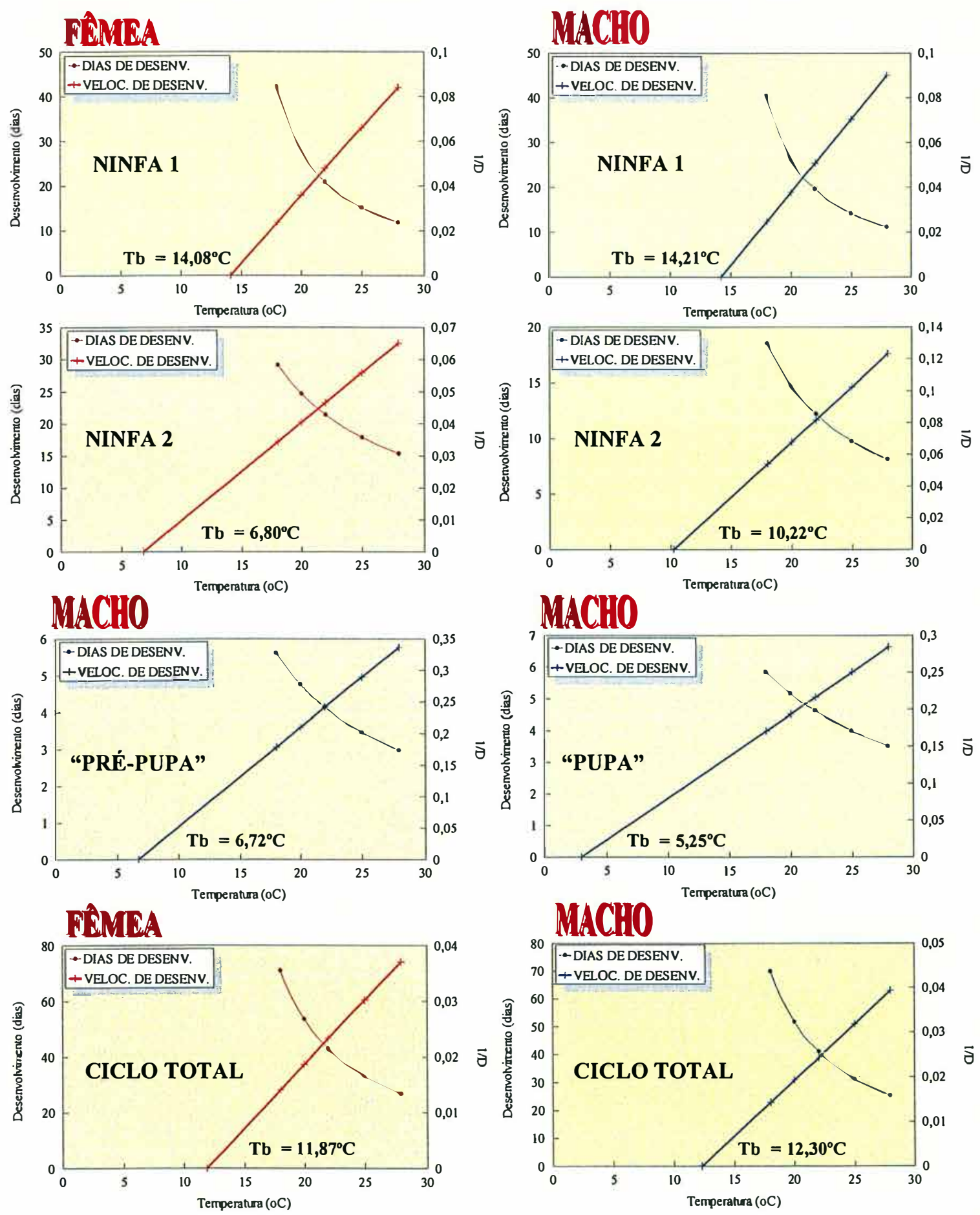

Figura 14. Curvas de velocidade dos diferentes ínstares de fêmeas e machos de $S$. articulatus em folhas de C. limonia. UR: $60 \pm 10 \%$; fotofase: 14 horas. 
Tabela 12. Número provável de gerações de $S$. articulatus em cinco regiões citrícolas do Estado de São Paulo, com base na sua constante térmica.

\begin{tabular}{|c|c|c|c|c|}
\hline \multirow[t]{2}{*}{ Região } & \multicolumn{2}{|c|}{$\begin{array}{l}\text { Graus dia anual } \\
\text { (GD) }\end{array}$} & \multicolumn{2}{|c|}{$\begin{array}{l}\text { Número de gerações /ano } \\
(\mathrm{n})\end{array}$} \\
\hline & macho & fêmea & macho & fêmea \\
\hline Limeira & $2.598,80$ & $2.755,75$ & 6,52 & 6,33 \\
\hline Araraquara & $3.467,50$ & $3.624,45$ & 8,70 & 8,33 \\
\hline Bebedouro & $3.905,50$ & $4.062,45$ & 9,80 & 9,34 \\
\hline Barretos & $4 . .015,00$ & $4.171,95$ & 10,07 & 9,59 \\
\hline São José do Rio Preto & $4.088,00$ & 4244,95 & 10,25 & 9,75 \\
\hline
\end{tabular}

A duração média de uma geração (T) de S. articulatus, isto é, tempo que decorre da emergência dos pais ao aparecimento dos descendentes, apresentou uma relação inversa com o aumento da temperatura, na faixa de 18 a $28^{\circ} \mathrm{C}$, variando de $136,33\left(18^{\circ} \mathrm{C}\right)$ a $69,57 \operatorname{dias}\left(28^{\circ} \mathrm{C}\right)$.

A razão infinitesimal $\left(r_{m}\right)$ aumentou com a elevação da temperatura, também no intervalo de 18 a $28^{\circ} \mathrm{C}$, variando de 0,182 a 0,455 (Tabela 13 ).

Os maiores valores para a razão finita de aumento $(\lambda)$, isto é, o número de fêmeas adicionadas à população por fêmea, foram obtidos nas temperaturas de 25 e $28^{\circ} \mathrm{C}$ (Tabela 13).

Portanto, através da tabela de vida de fertilidade, que é muito utilizada para avaliar o desempenho biológico de insetos, especialmente para comparar o seu desenvolvimento em diferentes condições abióticas (Parra, 1997), pôde-se constatar que as temperaturas mais adequadas ao desenvolvimento do inseto, são as de 25 e $28^{\circ} \mathrm{C}$. 
Tabela 13. Duração média da geração $(T)$, taxa líquida de reprodução $\left(R_{0}\right)$, razão infinitesimal de aumento $\left(\mathrm{r}_{\mathrm{m}}\right)$ e razão finita de aumento $(\lambda)$ para $S$. articulatus em diferentes temperaturas. Umidade $60 \pm 10 \%$; fotofase 14 horas.

\begin{tabular}{ccccc}
\hline $\begin{array}{c}\text { Temperatura } \\
\left({ }^{\circ} \mathrm{C}\right)\end{array}$ & $\mathrm{R}_{\mathrm{o}}$ & $\mathrm{T}$ & $\mathrm{r}_{\mathrm{m}}$ & $\lambda$ \\
\hline 18 & 11,950 & 136,332 & 0,0182 & 1,0190 \\
20 & 13,770 & 122,500 & 0,0214 & 1,0224 \\
22 & 17,908 & 97,273 & 0,0296 & 1,0312 \\
25 & 29,207 & 78,537 & 0,0429 & 1,0455 \\
28 & 23,817 & 69,576 & 0,0455 & 1,0483 \\
30 & 13,944 & 90,202 & 0,0292 & 1,0307 \\
\hline
\end{tabular}

\subsection{Observações morfológicas}

$1^{0}$ ínstar (ninfa I móvel): corpo oval, antenas com seis segmentos (Figura 15A), último segmento mais comprido que os demais, providos de um par de cerdas sensoriais em cada segmento antenal, último segmento com uma cerda apical (Figura 15B1). Olhos localizados lateralmente (Figura 15A2) e três cerdas cefálicas (Figura 15A3). Abdômen com marcada segmentação, apresentando esboços de lóbulos pigidiais. Último segmento do abdômen com dois filamentos anais bem desenvolvidos (Figura 16A). Pernas bem desenvolvidas e não ultrapassando a margem lateral do corpo (Figura 15C). Tarso com duas garras e digítulos originando-se do tarso e do unguis (Figura 15D).

20 ínstar (ninfa II fixa): corpo piriforme (ninfa da fêmea). Antenas reduzidas a tubérculos (Figura 17D1). Abdômen apresentando três lóbulos centrais 
proeminentes na extremidade caudal (Figura $16 \mathrm{Cl}$, 2, 3). Ausência de filamentos anais. Pigídio com cerdas marginais glandulares (Figura 15C4) e macroductos dorsomarginais (Figura 16C5). Anel anal esclerotizado (Figura 16C6). Corpo ovalado (ninfa do macho). Antenas reduzidas a tubérculos. Abdômen com margem lisas, com ausência de lóbulos caudais e cerdas glandulares (Figura 16D1). Pernas vestigiais.

Prépupa: antenas curtas, alojadas no interior de um envoltório (macho) (Figuras 20A e B). Genitália pouco desenvolvida, alojada no interior do segmento oito (Figuras 20B e C1).

Pupa: antenas quase alcançando a região do primeiro par de pernas (macho) (Figura 20B). Genitália com cerdas na base (Figura 20D1).

Adulto: fêmeas com corpo dividido em prossoma e póssoma (Figura $17 A 1,2)$. Prossoma semicircular e separado do póssoma por uma constrição bem marcada, apresentando uma pequena protuberância (Figura 17B). Antenas atrofiadas, rostro com canal alimentar (Figuras 17A e 17C). Presença de dois pares de espiráculos respiratórios, um no prossoma e outro no possoma (Figuras 17B1,2). Abdômen com oito segmentos, pigídio formado pelos três últimos segmentos (Figura 17A3) com quatro lóbulos na extremidade caudal (Figuras 18B e 18C), sendo dois médios (L1 e L2) e dois laterais (L3 e L4) (Figura 18C). Lóbulos com aspecto ondulado (Figuras 18C1,2,3,4), com duas placas pouco desenvolvidas entre os lóbulos L1 e L2. Lóbulos L3 e L4 com duas placas mais desenvolvidas (Figura 18B). A partir da L3 e L4 observa-se três placas franjadas e a quarta espiniforme (Figuras 18D1,2,3,4). Duas séries de ductos glandulares nas laterais do pigídio (Figura 18C). Vulva linguliforme (Figura 18A) circundada por glândulas perivulvares (Figura 19A). Pernas atrofiadas.

Machos com cabeça de forma irregular, arredondada com par de olhos dorsais e um par de olhos ventrais. Ocelos laterais (Figura 21A1). Antenas moniliformes com oito segmentos, apresentando numerosas cerdas sensoriais. Protórax membranoso; mesotórax esclerotizado. Asas anteriores com o primeiro par apresentando venação 
reduzida e o segundo em forma de halteres. Pernas longas, delgadas. Tarsos segmentados com uma garra. Abdômen ligeiramente cônico, com oito segmentos. Os segmentos pré-genitais membranosos (Figura 21C), segmento oito cônico, alojando o edeago (Figuras 21C e D).

Carapaça: arredondada, com dois sulcos que indicam as linhas das exúvias (Figuras 19C1,2). Carapaça constituída por filamentos glandulares secretados pela fềmeas adulta (Figura 19D1).

Discussão: a identificação dos exemplares de $S$. articulatus é baseada principalmente nos caracteres da fêmea. Ferris (1938) não conseguiu observar a presença de tubérculos antenais nas fềmeas de $2^{0}$ ínstar e nos adultos, devido a pequena capacidade de aumento dos equipamento óticos da época. Comentando em seu trabalho que o lóbulo 4 não era conspícuo. Entretanto, mesmo em trabalhos recentes tais como o de Dziedzicka \& Karnkowski (1990) que também caracterizaram S. articulatus, não observaram a presença do lóbulo 4 na fềmea adulta.

O método convencional (secagem ao ponto crítico) mostrou-se bastante eficiente para a caracterização geral morfológica da região do pigídio. Entretanto, o restante do corpo da cochonilha apresentou-se colapsado.

A análise do material preparado por secagem em dessecador e cobertura com ouro, ao contrário do método convencional, permitiu a observação do corpo da cochonilha sem deformações. A caracterização da região do pígidio não foi possível através desta técnica. 




Figura 15. S. articulatus A. Antena da ninfa móvel (115X). B. Último segmento antenal (155X). C. Parte ventral da ninfa móvel (70X). D. Tarso posterior da ninfa móvel (210X). 


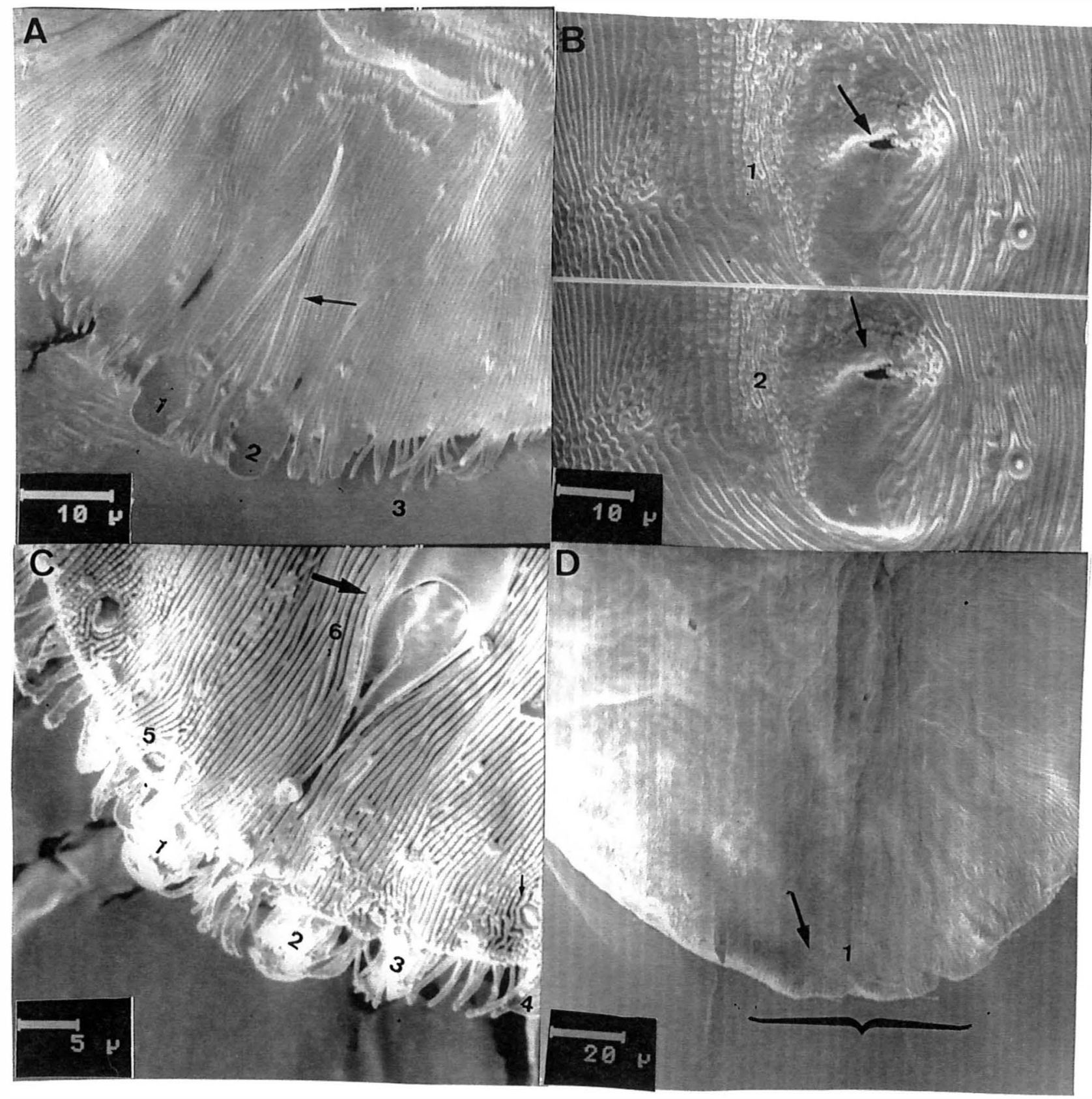

Figura 16. S. articulatus. A. Pigídio da ninfa móvel (150X). B. Espiráculos respiratórios da fêmea adulta (125X). C. Pigídio da ninfa II (fêmea) (202X). D. Pigídio da ninfa II (macho) (60X). 


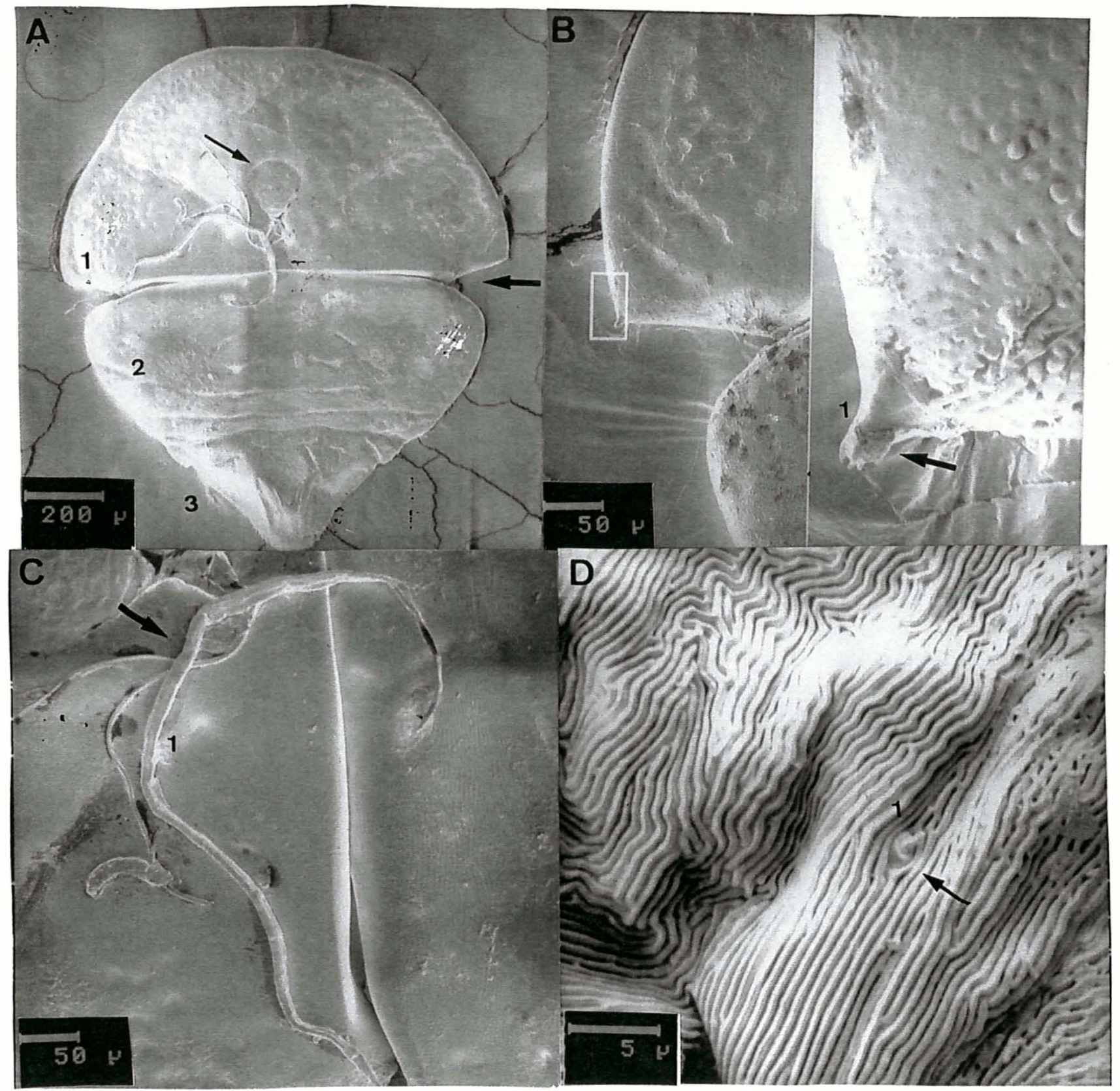

Figura 17. S. articulatus. A. Prossoma e possoma, vista ventral (8X). B. Protuberância da margem lateral do prossoma (20X). C. Aparelho bucal da fềmea adulta (20X). D. Tubérculo antenal da fêmea adulta (300X). 


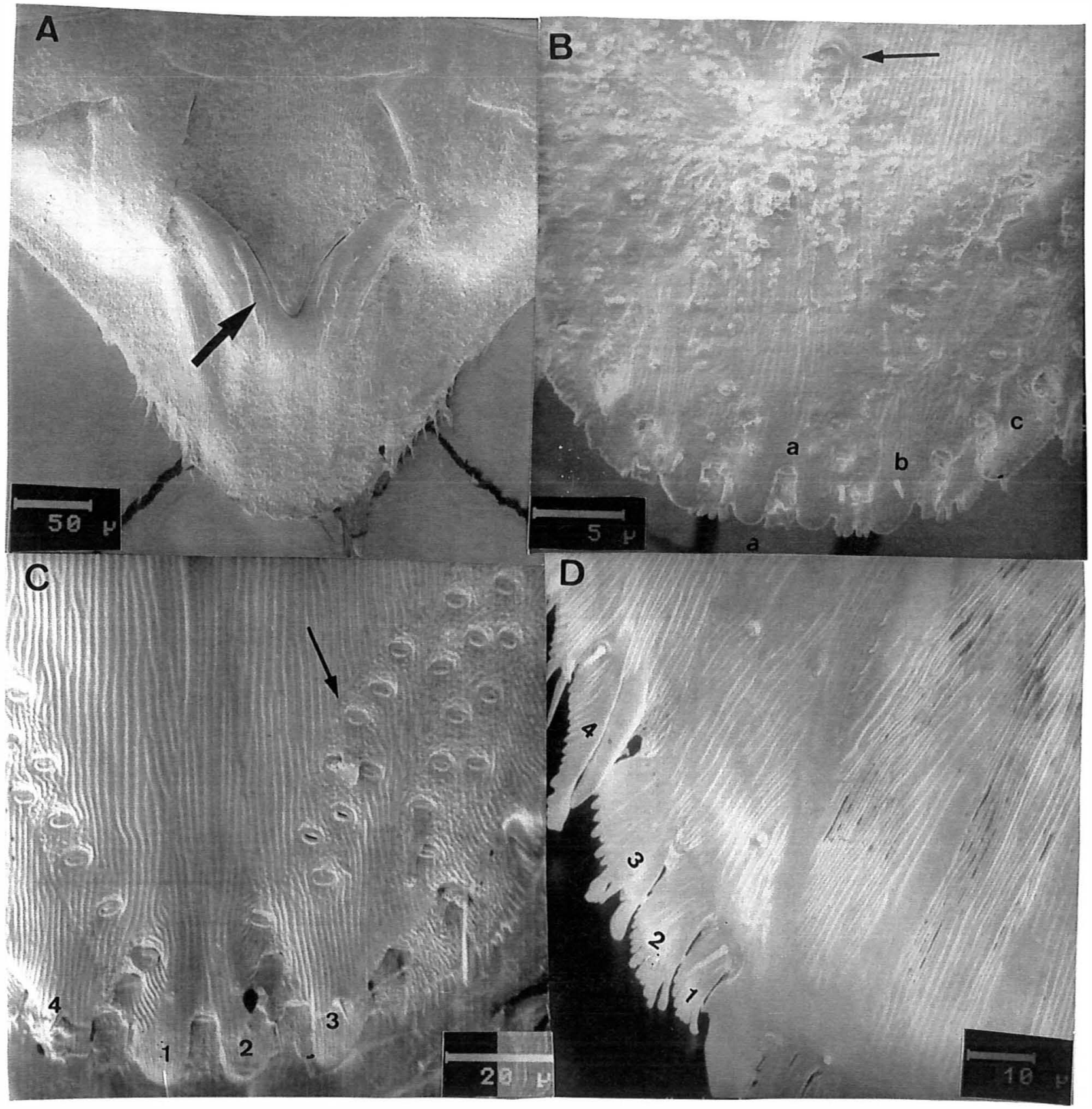

Figura 18. S. articulatus. Pigídio da fêmea adulta apresentando detalhes da vulva (25X). B. Margem posterior do pigídio da fềmea adulta (67X). C. Pigídio em vista ventral apresentando detalhes dos lóbulos e ductos glandulares da fêmea adulta (82X). D. Detalhe das placas localizadas na margem lateral do pigídio da fêmea adulta (110X). 


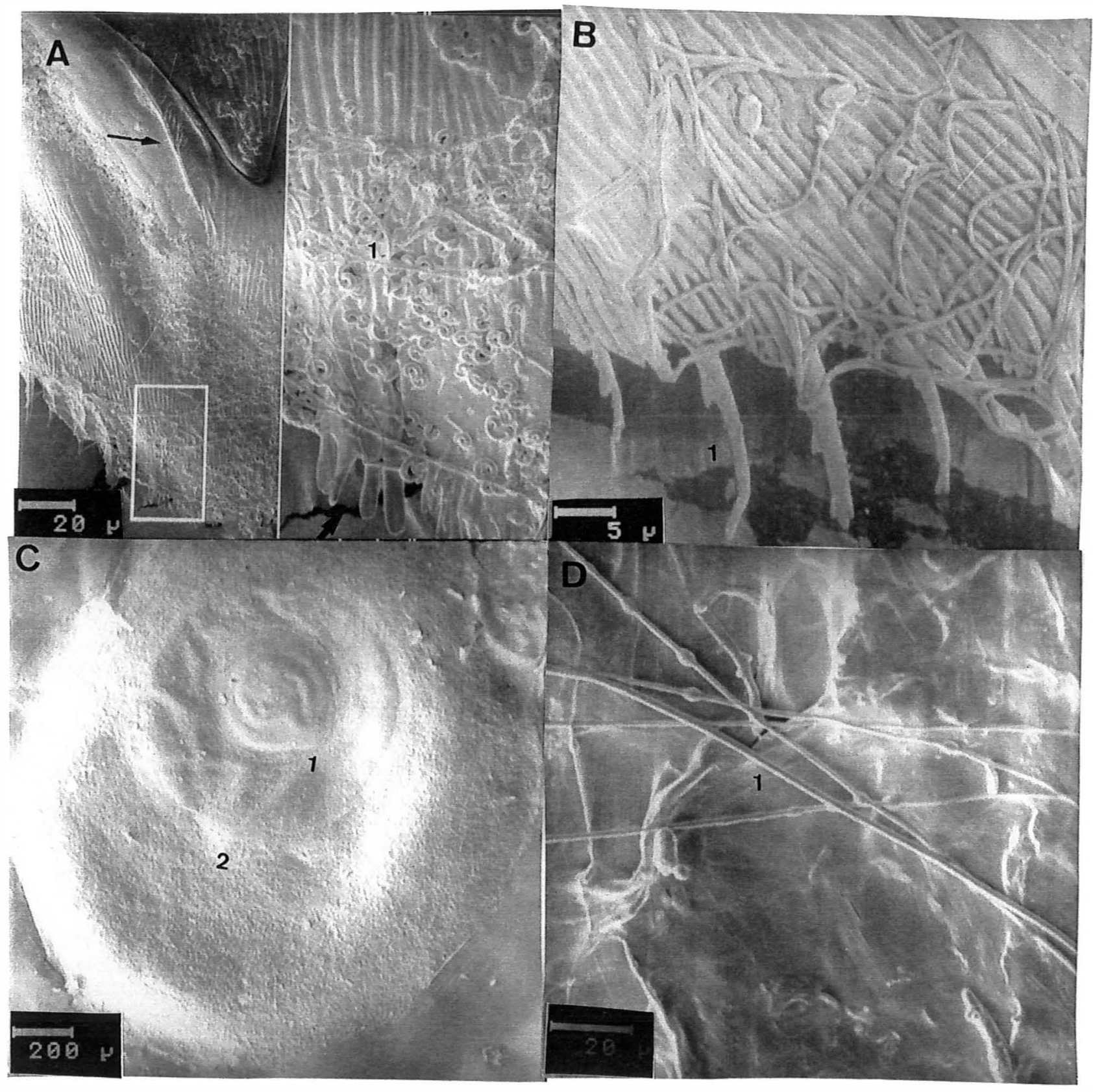

Figura 19. S. articulatus. A. Pigídio da fêmea adulta em vista ventral apresentando detalhes dos poros perivulvares (46X). B. Filamentos glandulares da margem lateral do pigídio (200X). C. Carapaça da cochonilha (5X). D. Filamentos da carapaça (290X). 


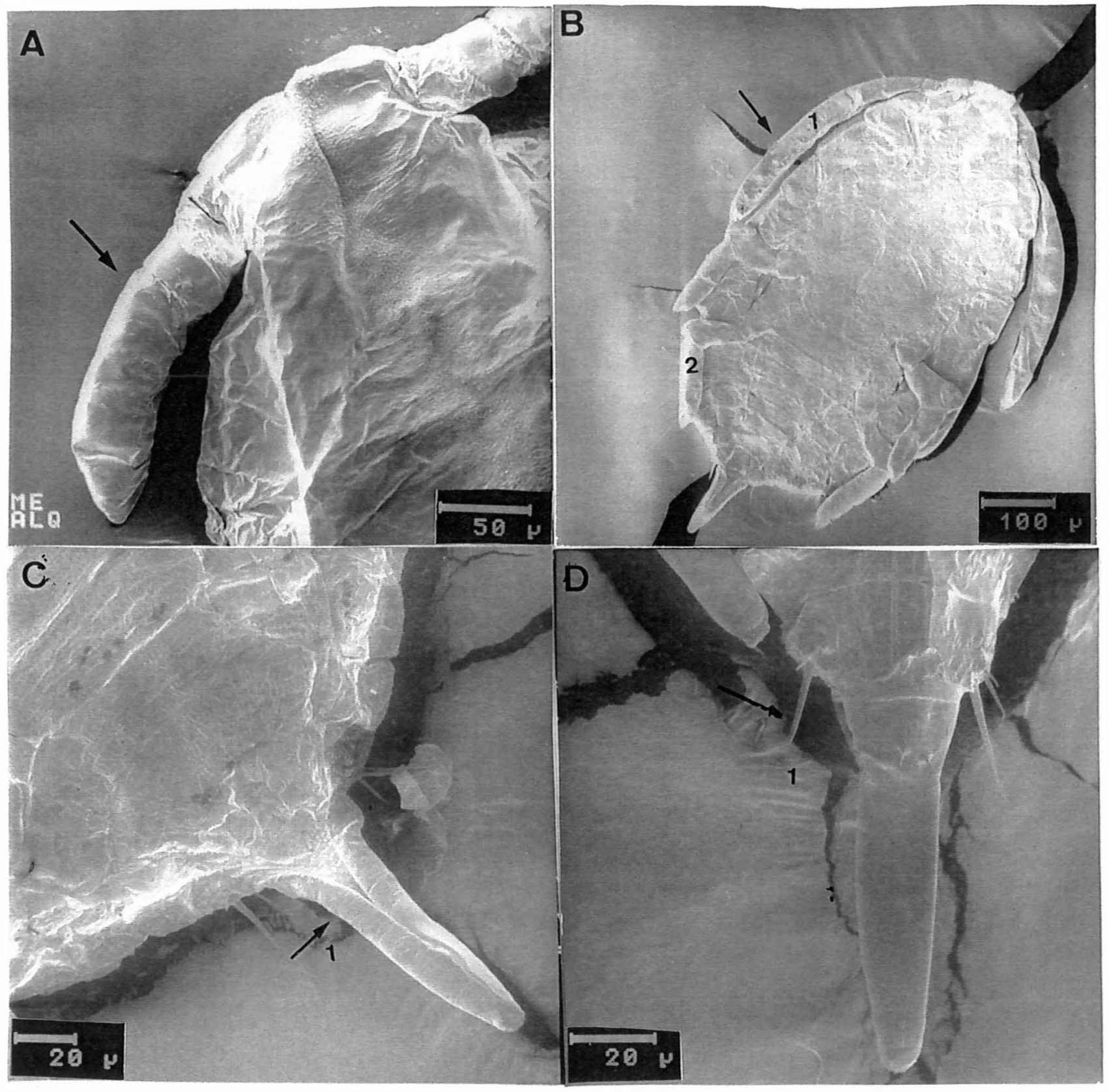

Figura 20. S. articulatus. A. Antena da prépupa (macho) (30X). B. Pupa (macho) em vista dorsal (12X). C. Pigídio prépupa (macho) (50X). D. Pigideo da pupa (macho) (50X). 


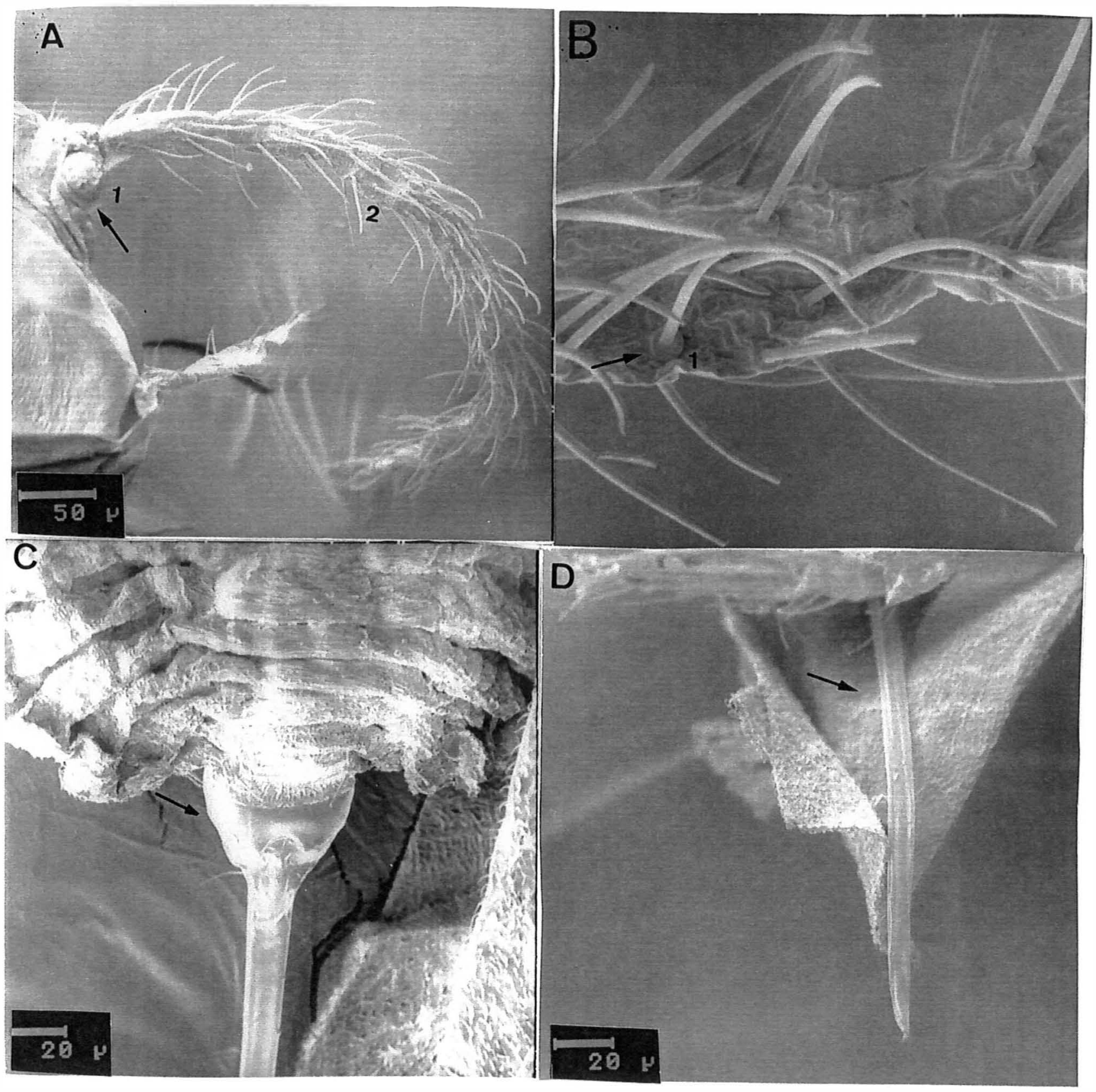

Figura 21. S. articulatus. A. Antena do macho adulto (25X). B. Segmento antenal (macho) apresentando as cerdas sensoriais. C. Último segmento do pigídeo do macho adulto (50X). D. Edeago do macho adulto (50X). 


\subsection{Efeito da umidade relativa do ar na biologia de $S$. articulatus}

A duração média do desenvolvimento de fêmeas (ninfa móvel - adulto) foi afetada significativamente pelas umidades relativas do ar (Tabela 14). Houve diferença entre os ínstares para fêmeas de S. articulatus, sendo o primeiro mais curto em todas as umidades relativas do ar. A tendência, para ambos os ínstares, foi semelhante em todas as condições, sendo que o ciclo total da cochonilha foi mais longo a $30 \%$, decrescendo tal duração até $70 \%$ de umidade relativa do ar. A partir deste ponto, considerado o mais adequado para as fềmeas desta espécie, o ciclo novamente começou a aumentar, indicando uma provável inadequação das umidades relativas mais elevadas (Tabela 14). Para machos, o ciclo total também foi decrescente na faixa de 30 a $70 \%$ de umidade relativa do ar, aumentando novamente a partir de $70 \%$. Aparentemente, a umidade relativa do ar afeta igualmente os sexos de $S$. articulatus, pois a tendência foi a mesma nas diferentes umidades relativas, com durações semelhantes (Tabela 15). No caso dos machos, o primeiro e segundo ínstares tiveram as menores durações, decrescendo na faixa de 30 a $70 \%$ e aumentando na umidade relativa mais elevada. A umidade relativa, aparentemente, teve menor efeito sobre o terceiro e quarto ínstares, que suportaram melhor as umidades relativas mais baixas, e tiveram menores durações em relação ao primeiro e segundo ínstares. Em geral, a umidade relativa de $70 \%$ foi mais adequada para ambos os sexos de $S$. articulatus (Tabelas 14 e 15).

A viabilidade, para machos e fêmeas, foi baixa em todas as umidades relativas. Em contraposição à duração, a viabilidade não foi afetada pelas diferentes umidades relativas (Tabelas 16 e 17). Apenas o primeiro ínstar, fase de fixação, foi influenciado pela umidade, ocorrendo maior mortalidade a $30 \%$ de umidade relativa. A umidade relativa de $70 \%$ foi a mais adequada para a fixação do inseto (Tabelas 16 e 17). Para as fêmeas, no primeiro ínstar, também ocorreu alta mortalidade, aparentemente como característica do inseto, pois tal mortalidade independeu da umidade relativa (Tabela 16). Para machos, a exemplo das fêmeas, ocorreu alta mortalidade em todas as umidades relativas, para o primeiro ínstar, sendo que a partir daí (segundo, terceiro e 
quarto ínstares), as viabilidades foram altas (Tabela 17). A mortalidade no ciclo total de machos e fềmeas foi alta, ao redor de 65\% (Figura 22).

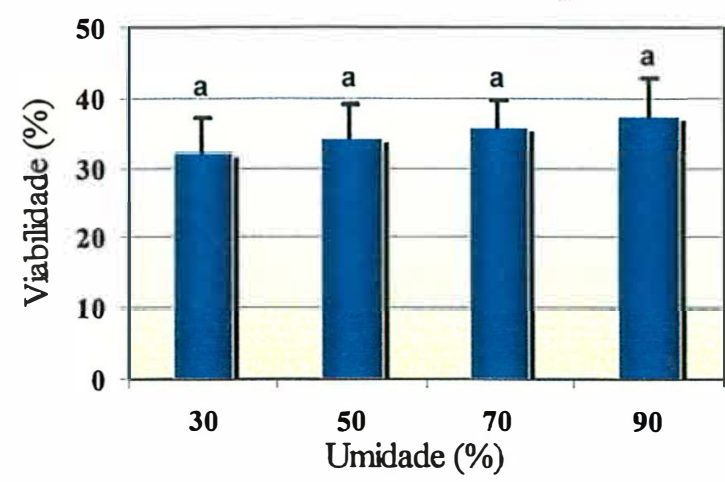

A

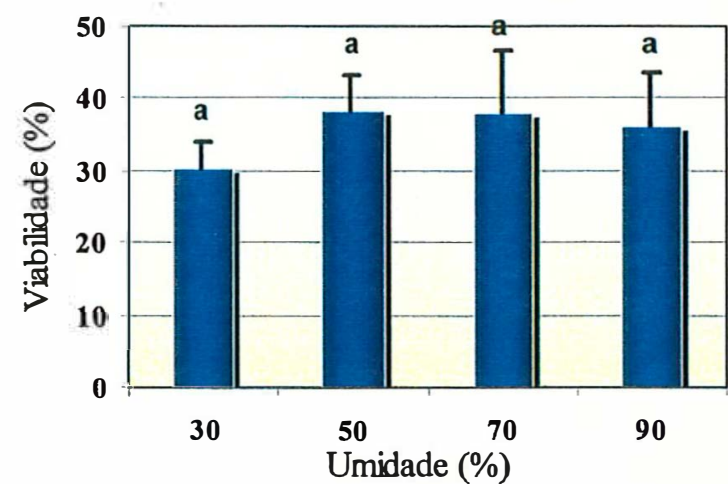

B

Figura 22. Viabilidade (\%) do ciclo total (fase móvel - adulto) de fềmeas (A) e machos (B) de $S$. articulatus sobre mudas de $C$. limonia em diferentes umidades relativas do ar. Temperatura: $25 \pm 2{ }^{\circ} \mathrm{C}$; fotofase: 14 horas. Barras seguidas das mesmas letras não diferem significativamente pelo teste de Ducan a 5\%.

Período de 'pré-oviposição' e 'oviposição': a condição que proporcionou um encurtamento do período de 'pré-oviposição' e um alongamento da 'oviposição', portanto, favorecendo o inseto, foi a umidade relativa de $70 \%$. À medida que se aumentou a umidade relativa, na faixa de 30 a $70 \%$, os períodos de 'préoviposição' e 'oviposição' foram diminuindo ou aumentando, respectivamente (Tabela 18). As umidades mais altas (90\%) foram desfavoráveis à S. articulatus.

Fecundidade: constataram-se diferenças significativas para a fecundidade em diferentes umidades relativas. Como para os demais parâmetros, a umidade relativa mais favorável foi a de 70\%, com uma produção de 108 ninfas móveis/fêmea. A fecundidade foi crescente na faixa de 30 a 70\%, voltando a decrescer com altas umidades relativas (Tabela 19). 
Tabela 14. Duração (dias) das fases imaturas e do ciclo total (da fase móvel - adulto) de fềmeas de $S$. articulatus sobre mudas de $C$. limonia em diferentes umidades relativas do ar. Temperatura: $25^{\circ} \mathrm{C}$; fotofase: 14 horas.

\begin{tabular}{cccc}
\hline $\begin{array}{c}\text { Umidade } \\
(\%)\end{array}$ & $\begin{array}{c}1^{\mathbf{0}} \text { ínstar (ninfa 1) } \\
(\text { fases móvel + fixa) }\end{array}$ & $\begin{array}{c}2^{\mathbf{0}} \text { ínstar } \\
(\text { ninfa } 2)\end{array}$ & Ciclo total \\
\hline 30 & $18,48 \pm 1,14 \mathrm{a}$ & $22,45 \pm 1,01 \mathrm{a}$ & $41,30 \pm 0,85 \mathrm{a}$ \\
& $(18-19)$ & $(22-23)$ & $(41-42)$ \\
50 & $13,72 \pm 1,19 \mathrm{c}$ & $21,10 \pm 1,22 \mathrm{~b}$ & $35,00 \pm 1,38 \mathrm{c}$ \\
& $(13-14)$ & $(20-21$ & $(34-35)$ \\
70 & $12,60 \pm 0,82 \mathrm{~d}$ & $16,73 \pm 0,91 \mathrm{~d}$ & $29,52 \pm 1,05 \mathrm{~d}$ \\
& $(12-13)$ & $(16-17)$ & $(29-30)$ \\
90 & $16,00 \pm 0,95 \mathrm{~b}$ & $19,45 \pm 1,95 \mathrm{c}$ & $35,58 \pm 1,39 \mathrm{~b}$ \\
& $(15-16)$ & $(19-20)$ & $(35-36)$
\end{tabular}

Médias seguidas de letras diferentes, na vertical, diferem estatisticamente entre si, pelo teste de Duncan, ao nivel de $5 \%$ de probabilidade;

Valores entre parênteses expressam o intervalo de variação, ao nível de $5 \%$ de probabilidade.

Tabela 15. Duração (dias) das fases imaturas e do ciclo total ( fase móvel - adulto) de machos de S. articulatus sobre mudas de C. limonia em diferentes umidades relativas do ar. Temperatura: $25^{\circ} \mathrm{C}$; fotofase: 14 horas.

\begin{tabular}{cccccc}
\hline $\begin{array}{c}\text { Umidade } \\
(\%)\end{array}$ & $\begin{array}{c}1^{\circ} \text { instar (ninfa 1) } \\
\text { (fase móvel + fixa) }\end{array}$ & $\begin{array}{c}2^{\circ} \text { ínstar } \\
(\text { ninfa 2) }\end{array}$ & $\begin{array}{c}3^{\circ} \text { instar ("pré- } \\
\text { pupa") }\end{array}$ & $\begin{array}{c}4^{\circ} \text { instar } \\
(" p u p a ")\end{array}$ & $\begin{array}{c}\text { Ciclo } \\
\text { total }\end{array}$ \\
\hline 30 & $16,51 \pm 0,79 \mathrm{a}$ & $14,78 \pm 0,78 \mathrm{a}$ & $4,56 \pm 0,50 \mathrm{a}$ & $4,88 \pm 0,40 \mathrm{a}$ & $40,17 \pm 0,75 \mathrm{a}$ \\
& $(16-17)$ & $(14-15)$ & $(4-5)$ & $(4-5)$ & $(39-40)$ \\
50 & $12,21 \pm 1,82 \mathrm{c}$ & $12,96 \pm 1,13 \mathrm{c}$ & $4,63 \pm 0,48 \mathrm{a}$ & $4,84 \pm 0,54 \mathrm{a}$ & $33,43 \pm 1,16 \mathrm{c}$ \\
& $(12-13)$ & $(12-13)$ & $(4-5)$ & $(4-5)$ & $(33-34)$ \\
70 & $10,97 \pm 0,82 \mathrm{~d}$ & $10,92 \pm 1,40 \mathrm{~d}$ & $3,67 \pm 0,47 \mathrm{~b}$ & $4,52 \pm 0,50 \mathrm{~b}$ & $29,17 \pm 0,82 \mathrm{~d}$ \\
& $(10-11)$ & $(10-11)$ & $(3-4)$ & $(4-5$ & $(29-30)$ \\
90 & $13,28 \pm 0,77 \mathrm{~b}$ & $13,77 \pm 0,92 \mathrm{~b}$ & $4,59 \pm 0,56 \mathrm{a}$ & $4,76 \pm 0,46 \mathrm{a}$ & $34,97 \pm 0,94 \mathrm{~b}$ \\
& $(13-14)$ & $(13-14)$ & $(4-5)$ & $(4-5)$ & $(34-35)$ \\
\hline
\end{tabular}

Médias seguidas de letras diferentes, na vertical, diferem estatisticamente entre si, pelo teste de Duncan, ao nivel de $5 \%$ de probabilidade;

Valores entre parênteses expressam o intervalo de variação, ao nível de $5 \%$ de probabilidade. 
Flanders (1951) relatou que as umidades de 30 e $40 \%$ foram letais às ninfas móveis de $A$. aurantii, pois observou que elas não saíram da carapaça matema, comportamento observado no presente trabalho à temperatura de $18^{\circ} \mathrm{C}$ e umidade de $30 \%$. O mesmo autor assumiu que o inseto necessita de umidade relativa acima de $50 \%$, sendo a reprodução máxima registrada a $70 \%$, corroborando os resultados observados no presente trabalho.

Em geral, a taxa de oviposição foi mais elevada a partir de 15 dias, caindo a partir dos 30 dias, para todas as umidades, com exceção da de $30 \%$, na qual a fecundidade diminuiu a partir de 25 dias (Figura 23).

Longevidade de fêmeas e machos: a longevidade foi influenciada significativamente pela umidade relativa, tanto para fêmeas como para machos, sendo tal efeito mais evidente em machos. Registrou-se a maior longevidade das fềmeas (72 dias) a 70\% de umidade, não diferindo, porém, do valores observados a $90 \%$ (61 dias) e a $30 \%$ (66 dias) (Tabela 18). Para os machos, a maior longevidade foi de 36 horas, a $70 \%$, diminuindo com o decréscimo da umidade, até atingir 19 horas a $30 \%$ de umidade relativa. Na mais alta umidade $(90 \%)$, registrou-se diminuição da longevidade (Tabela 18).

Tabela 16. Viabilidade (\%) da fase móvel (fixação), das fases imaturas de fềmeas de $S$. articulatus sobre mudas de $C$. limonia em diferentes umidades relativas do ar. Temperatura: $25 \pm 2^{\circ} \mathrm{C}$; fotofase: 14 horas.

\begin{tabular}{ccccc}
\hline \multicolumn{4}{c}{ Viabilidade (\%) } \\
\hline $\begin{array}{c}\text { Umidade } \\
(\%)\end{array}$ & $\mathrm{n}^{*}$ & $\begin{array}{c}1^{\circ} \text { ínstar }{ }^{* *} \text { (ninfas } \\
\text { móveis - fixação) }\end{array}$ & $1^{\text {o }}$ ínstar (ninfas fixas) & $\begin{array}{c}2^{\circ} \text { ínstar } \\
\text { (ninfa 2) }\end{array}$ \\
\hline 30 & 50 & $56,00 \pm 1,63 \mathrm{c}$ & $46,43 \pm 2,52 \mathrm{a}$ & $80,70 \pm 4,75 \mathrm{~b}$ \\
50 & 50 & $62,50 \pm 1,91 \mathrm{~b}$ & $37,59 \pm 5,24 \mathrm{a}$ & $97,91 \pm 4,16 \mathrm{a}$ \\
70 & 50 & $75,50 \pm 1,91 \mathrm{a}$ & $42,92 \pm 7,81 \mathrm{a}$ & $92,99 \pm 5,20 \mathrm{a}$ \\
90 & 50 & $62,50 \pm 3,41 \mathrm{~b}$ & $42,96 \pm 8,59 \mathrm{a}$ & $93,32 \pm 5,45 \mathrm{a}$ \\
\hline
\end{tabular}

Médias seguidas de letras diferentes, na vertical, diferem estatisticamente entre si, pelo teste de Duncan, ao nível de $5 \%$ de probabilidade;

*Número de fềmeas analisadas;

**Não há possibilidade de separação de sexos nessa fase de desenvolvimento da cochonilha; 

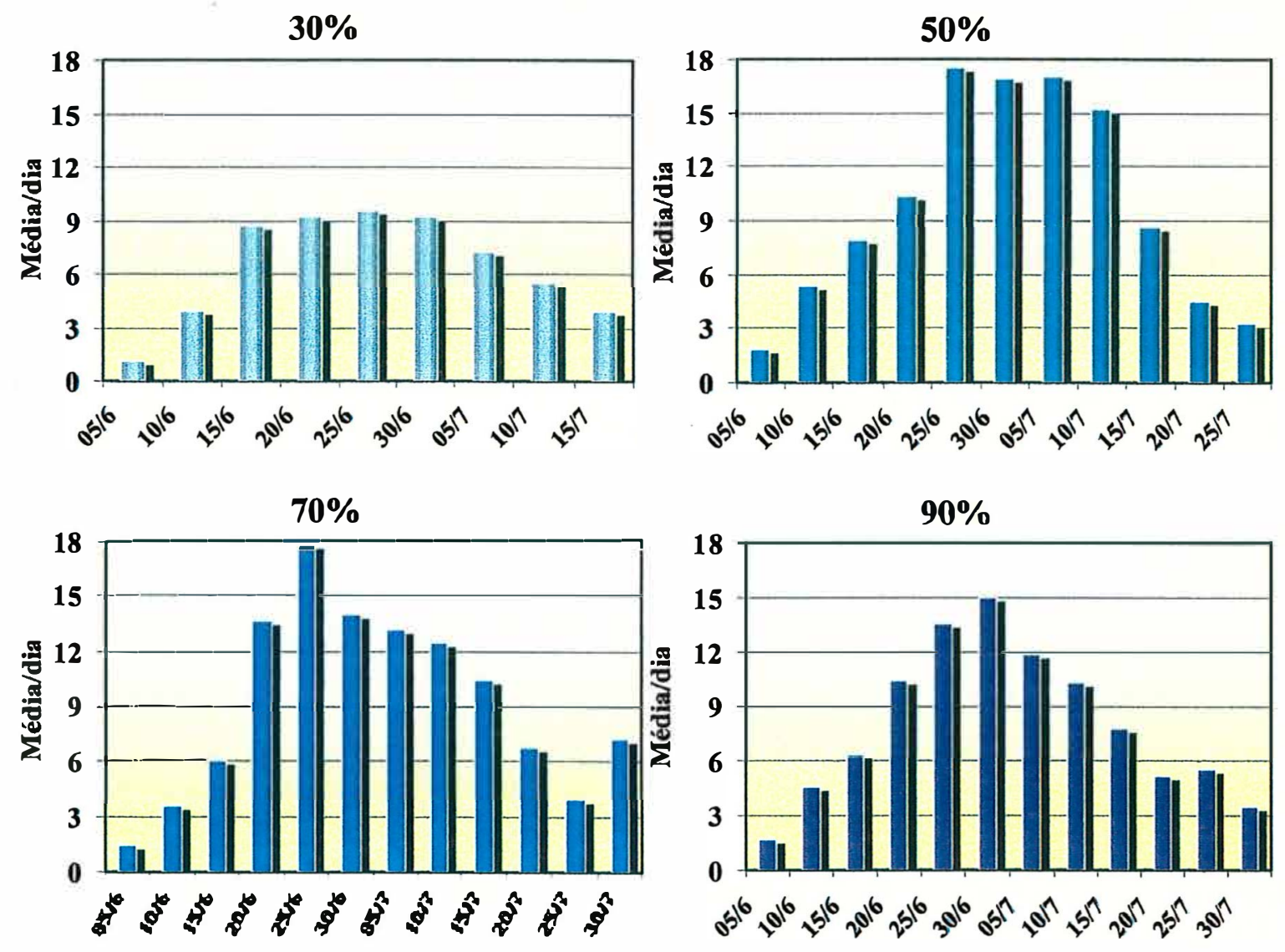

Figura 23. Ritmo de oviposição de $S$. articulatus em folhas de $C$. limonia em diferentes umidades relativas do ar. Temperatura: $25 \pm 2^{\circ} \mathrm{C}$; fotofase: 14 horas.

Rice \& Moreno (1970) verificaram que, a 50\%, não ocorreu o vôo dos machos de $A$. aurantii , sendo considerada ideal, para essa atividade, a umidade de $75 \%$.

Ciclo de vida: por não haver grandes diferenças na longevidade (Tabela 20), o período desde a fase móvel até a morte do adulto, aqui denominado de ciclo de vida, não apresentou grandes variações, mostrando uma tendência de alongamento a $30 \%$ de umidade relativa (Tabela 20 ).

Razão sexual: não foram verificadas diferenças significativas para essa variável, sendo os sexos afetados igualmente pelas diferentes umidades estudadas. 
Similarmente ao constatado para o efeito da temperatura (item 4.2.1.2), a razão sexual foi próxima de 0,5 (Tabela 21 ).

Tabela 17. Viabilidade (\%) da fase móvel (fixação), das fases imaturas de machos de $S$. articulatus sobre mudas de C. limonia em diferentes umidades relativas do ar. Temperatura: $25 \pm 2{ }^{\circ} \mathrm{C}$; fotofase: 14 horas.

\begin{tabular}{|c|c|c|c|c|c|}
\hline & \multicolumn{5}{|c|}{ Viabilidade (\%) } \\
\hline $\begin{array}{l}\text { Umidade } \\
\text { (\%) }\end{array}$ & $\begin{array}{c}1^{0} \text { instar } \\
\text { (ninfas móveis } \\
\text { - fixação) }\end{array}$ & $\begin{array}{c}1^{\circ} \text { instar } \\
\text { (ninfas fixas) }\end{array}$ & $\begin{array}{l}2^{\circ} \text { instar } \\
\text { (ninfa 2) }\end{array}$ & $\begin{array}{c}3^{0} \text { instar } \\
\text { ("pré-pupa") }\end{array}$ & $\begin{array}{l}4^{\circ} \text { ínstar } \\
\text { ("pupa") }\end{array}$ \\
\hline 30 & $56,00 \pm 1,63 \mathrm{c}$ & $43,71 \pm 5,68 a$ & $84,82 \pm 18,06 a$ & $91,45 \pm 11,01 \mathrm{a}$ & $94,72 \pm 6,11 \mathrm{a}$ \\
\hline 50 & $62,50 \pm 1,91 b$ & $51,21 \pm 7,77 \mathrm{a}$ & $91,32 \pm 6,77 \mathrm{a}$ & $98,33 \pm 3,33 \mathrm{a}$ & $89,23 \pm 4,73 \mathrm{a}$ \\
\hline 70 & $75,50 \pm 1,91 \mathrm{a}$ & $51,75 \pm 8,59 a$ & $87,81 \pm 11,43 \mathrm{a}$ & $92,09 \pm 6,94 \mathrm{a}$ & $93,16 \pm 5,01 \mathrm{a}$ \\
\hline 90 & $62,50 \pm 3,41 b$ & $50,70 \pm 10,83 a$ & $87,63 \pm 7,16 a$ & $96,87 \pm 6,25 \mathrm{a}$ & $97,72 \pm 4.54 \mathrm{a}$ \\
\hline
\end{tabular}

Médias seguidas de letras diferentes, na vertical, diferem estatisticamente entre si, pelo teste de Duncan, ao nível de $5 \%$ de probabilidade;

*Não há possibilidade de separação de sexos nessa fase de desenvolvimento da cochonilha;

Sobrevivência: em todas as umidades, para ambos os sexos, as curvas de sobrevivência ajustaram-se ao modelo matemático de Weibull (Sgrillo, 1982) (Figuras 24 e 25), sendo assim possível a previsão de produção em laboratório, para criações massais, baseando-se nas equações obtidas.

Com base nos resultados apresentados e discutidos no presente trabalho, pôde-se constatar que todas as fases de $S$. articulatus são influenciadas pela umidade e que, de maneira geral, umidades relativas acima de 50\% irão favorecê-la, sendo a de $70 \%$ considerada a ideal. Lima (1981) também considerou ideal, para Orthezia praelonga Douglas, umidade relativa em torno de $70 \%$. 

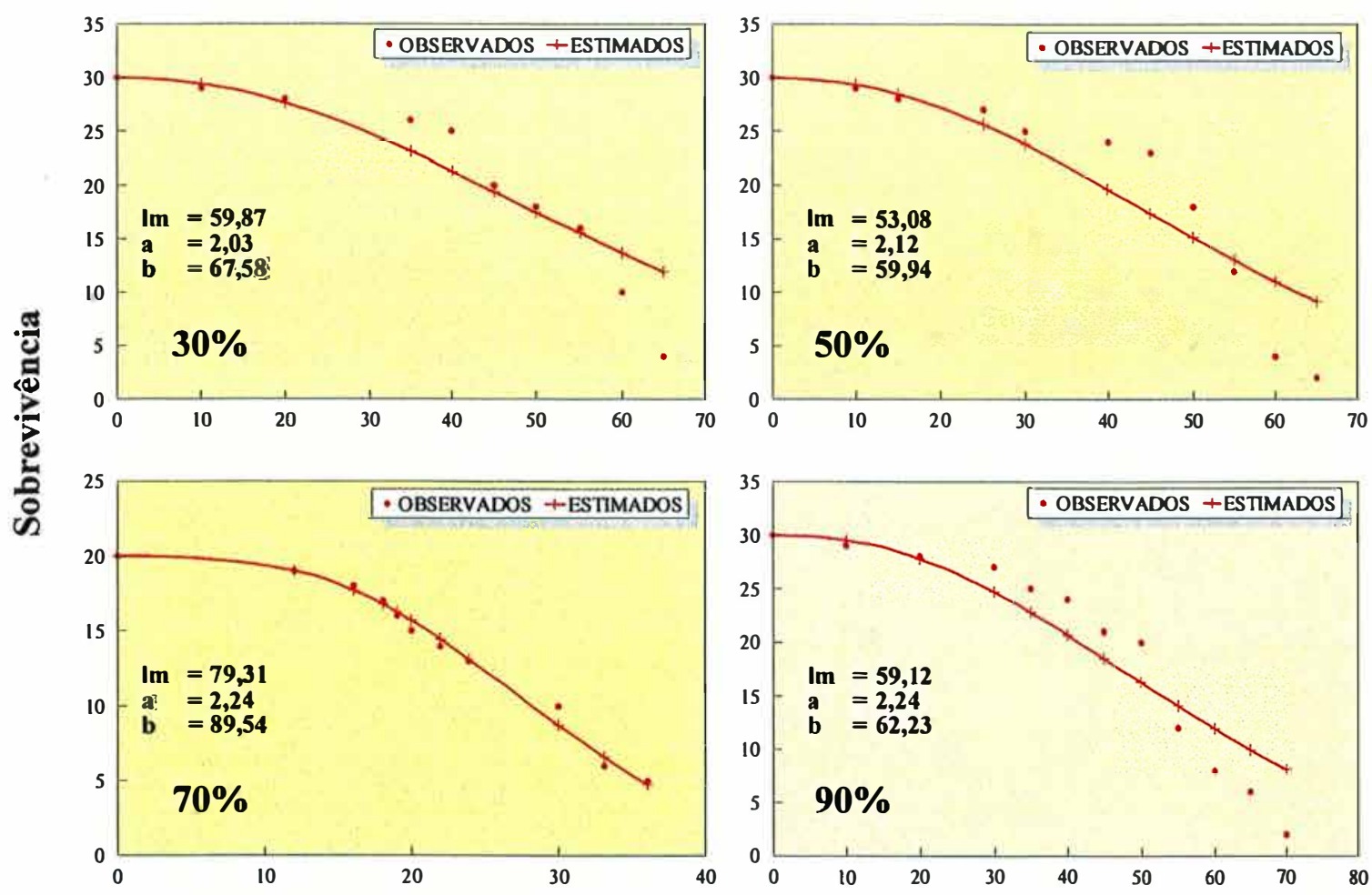

Dias

Figura 24. Curvas de sobrevivência de Weibull para fêmeas de S. articulatus em mudas de $C$. limonia em diferentes umidades relativas do ar. Temperatura: $25 \pm 2{ }^{\circ} \mathrm{C}$; fotofase: 14 horas. 

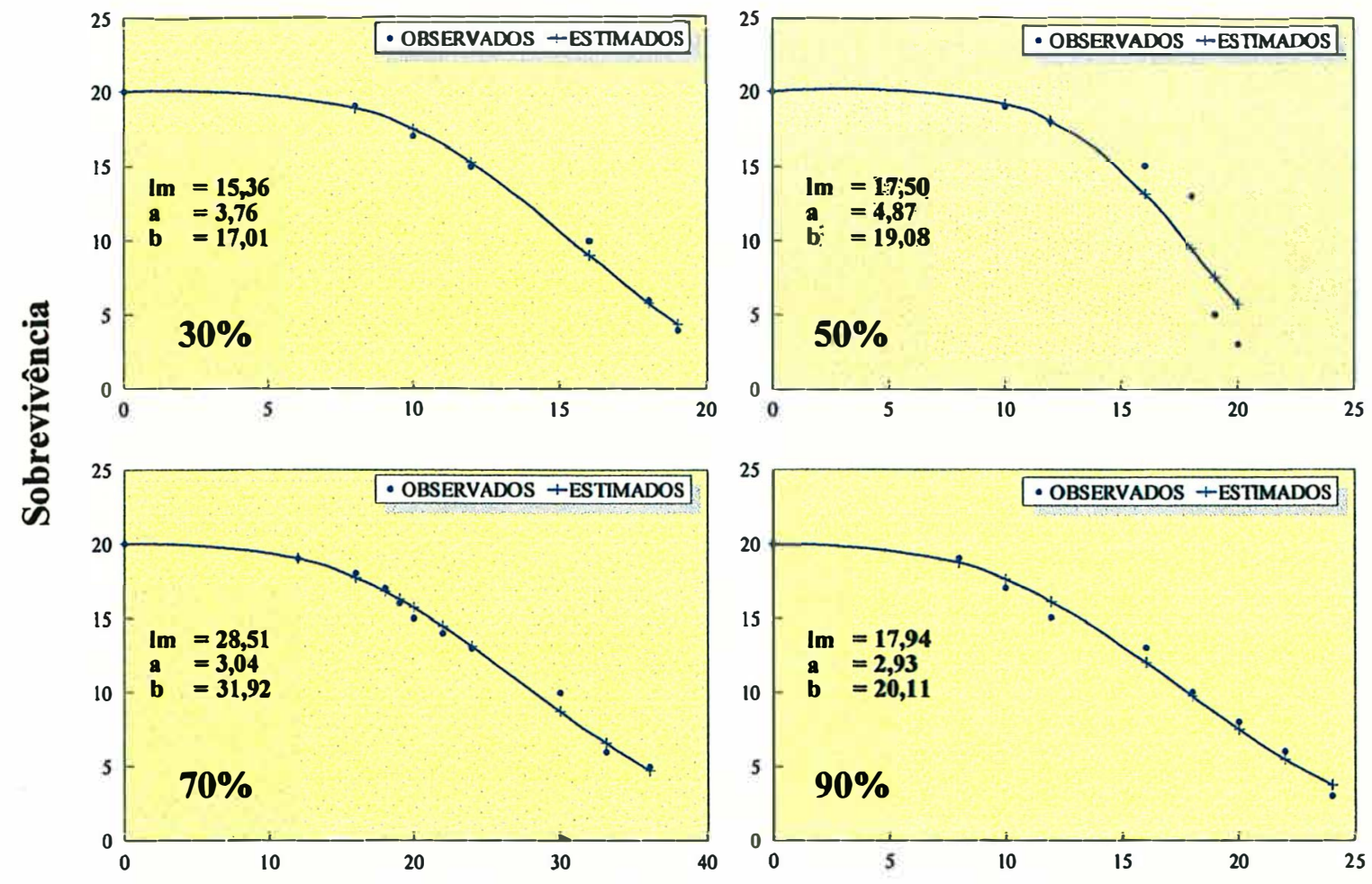

Dias

Figura 25. Curvas de sobrevivência de Weibull para machos de $S$. articulatus em mudas de $C$. limonia em diferentes umidades relativas do ar. Temperatura: $25 \pm 2^{\circ} \mathrm{C}$; fotofase: 14 horas. 
Dessa forma, provavelmente, o crescimento populacional da praga, em condições de campo, é diretamente proporcional ao aumento da umidade relativa, o que é confirmado pelos trabalhos realizados por diversos autores (Perruso \& Cassino, 1993; Pinto, 1995), os quais afirmaram que as épocas de maior infestação da cochonilha são períodos quentes e úmidos. Por outro lado, Nakano (1985) afirmou que a alta umidade favorece o desenvolvimento de fungos entomopatogênicos, responsáveis por grandes reduções na população de cochonilhas em geral e, com ênfase, a S. articulatus.

Tabela de vida de fertilidade: a influência da umidade relativa ficou bem definida através da tabela de vida de fertilidade, evidenciando ser a umidade relativa de $70 \%$ a mais adequada ao desenvolvimento da cochonilha, S. articulatus. Assim, a taxa líquida de reprodução $\left(\mathrm{R}_{\mathrm{o}}\right)$ de $S$. articulatus variou de 6,89 a 18,91 vezes, observando-se as maiores taxas de aumento a $70 \%$ de umidade, considerada a melhor para o desenvolvimento do inseto. A duração média de uma geração $(\mathrm{T})$ apresentou uma relação inversa com o aumento da umidade, variando de 74,38 dias (70\%) a 92,16 dias (30\%). A razão infinitesimal de aumento $\left(r_{m}\right)$ elevou-se com o incremento da umidade na faixa de 30 a $70 \%$. Os maiores valores de $\lambda$, ou seja, o número de fêmeas adicionadas à população por fềmea, foram obtidos às umidades de 50 e 70\% (Tabela 22).

Desta forma, a $70 \%$, a capacidade de aumento a cada geração é de 18,91 vezes; este valor adicionado ao encurtamento de uma geração, e ao maior número de fêmeas adicionadas à população por fêmea, credenciam a umidade relativa de $70 \%$ como a mais adequada para criação e desenvolvimento do inseto em pauta. 
Tabela 18. Duração dos períodos de "pré-oviposição", "oviposição" e longevidade de fềmeas e de machos de $S$. articulatus sobre mudas de $C$. limonia em diferentes umidades relativas do ar. Temperatura: $25 \pm 2^{\circ} \mathrm{C}$; fotofase: 14 horas.

\begin{tabular}{|c|c|c|c|c|}
\hline \multirow{2}{*}{$\begin{array}{l}\text { Umidade } \\
(\%)\end{array}$} & "Pré-oviposição" & "Oviposição" & \multicolumn{2}{|c|}{ Longevidade } \\
\hline & \multicolumn{2}{|c|}{ (dias) } & $\begin{array}{l}\text { Fêmea } \\
\text { (dias) }\end{array}$ & $\begin{array}{l}\text { Macho } \\
\text { (horas) }\end{array}$ \\
\hline 30 & $\begin{array}{c}33,22 \pm 1,74 a \\
(32-33)\end{array}$ & $\begin{array}{c}33,00 \pm 11,49 \mathrm{c} \\
(29-37)\end{array}$ & $\begin{array}{c}66,17 \pm 4,83 a b \\
(62-69)\end{array}$ & $\begin{array}{c}19,90 \pm 1,09 \mathrm{~d} \\
(19-20)\end{array}$ \\
\hline 50 & $\begin{array}{c}18,74 \pm 1,96 \mathrm{c} \\
(18-19)\end{array}$ & $\begin{array}{c}40,83 \pm 9,83 b \\
(37-44)\end{array}$ & $\begin{array}{c}59,59 \pm 2,93 b \\
(57-61)\end{array}$ & $\begin{array}{c}22,46 \pm 2,78 c \\
(21-23)\end{array}$ \\
\hline 70 & $\begin{array}{c}17,98 \pm 1,53 \mathrm{~d} \\
(17-18)\end{array}$ & $\begin{array}{c}54,16 \pm 8,61 \text { a } \\
(51-57)\end{array}$ & $\begin{array}{c}72,16 \pm 3,50 a \\
(69-74)\end{array}$ & $\begin{array}{c}36,84 \pm 5,34 \mathrm{a} \\
(35-38)\end{array}$ \\
\hline 90 & $\begin{array}{c}21,50 \pm 1,48 b \\
(21-22)\end{array}$ & $\begin{array}{c}40,50 \pm 12,27 b \\
(36-45)\end{array}$ & $\begin{array}{c}61,94 \pm 4,64 a b \\
(58-65)\end{array}$ & $\begin{array}{c}33,60 \pm 1,76 b \\
(33-34)\end{array}$ \\
\hline
\end{tabular}

Médias seguidas de letras diferentes, na vertical, diferem estatisticamente entre si, pelo teste de Duncan, ao nível de $5 \%$ de probabilidade;

Valores entre parênteses expressam o intervalo de variação, ao nível de $5 \%$ de probabilidade.

Tabela 19. Relação sexual e razão sexual de $S$. articulatus em folhas de C. limonia em diferentes umidades. Temperatura: $25 \pm 2{ }^{\circ} \mathrm{C}$; fotofase: 14 horas.

\begin{tabular}{cccc}
\hline $\begin{array}{c}\text { Umidade } \\
(\%)\end{array}$ & $\mathrm{n}^{*}$ & $\begin{array}{c}\text { Relação } \\
\text { sexual }\end{array}$ & $\begin{array}{c}\text { Razão } \\
\text { sexual }\end{array}$ \\
\hline 30 & 101 & $1,06: 1$ & 0,52 I \\
50 & 111 & $0,73: 1$ & 0,42 I \\
70 & 143 & $0,83: 1$ & 0,45 I \\
90 & 117 & $0,86: 1$ & 0,46 I \\
\hline
\end{tabular}

Médias seguidas do mesmo algarismo romano, não diferem entre si, pelo teste Qui-quadrado, ao nível de $5 \%$ de probabilidade.

*Número de adultos. 
Tabela 20. Fecundidade de $S$. articulatus criadas sobre mudas de C. limonia em diferentes umidades relativas do ar. Temperatura: $25 \pm 2{ }^{\circ} \mathrm{C}$; fotofase: 14 horas.

\begin{tabular}{ccc}
\hline $\begin{array}{c}\text { Umidade } \\
(\%)\end{array}$ & $\mathrm{n}^{*}$ & $\begin{array}{c}\text { Fecundidade } \\
\text { (ninfas móveis/fêmea) }\end{array}$ \\
\hline 30 & 30 & $\begin{array}{c}43,27 \pm 18,77 \mathrm{~d} \\
(36-50)\end{array}$ \\
50 & 30 & $\begin{array}{c}91,27 \pm 27,42 \mathrm{~b} \\
(81-101)\end{array}$ \\
70 & 30 & $\begin{array}{c}108,03 \pm 30,15 \mathrm{a} \\
(97-119)\end{array}$ \\
90 & 30 & $\begin{array}{c}71,73 \pm 28,97 \mathrm{c} \\
(61-82)\end{array}$ \\
\hline
\end{tabular}

Médias seguidas de letras diferentes, na vertical, diferem estatisticamente entre si, pelo teste de Duncan, ao nível de $5 \%$ de probabilidade;

Valores entre parênteses expressam o intervalo de variação, ao nivel de $5 \%$ de probabilidade;

*Número de ninfas móveis analisadas.

Tabela 21. Duração do ciclo de vida (fase móvel - morte do adulto) (dias) de fêmeas de S. articulatus sobre mudas de C. limonia em diferentes umidades relativas do ar. Temperatura: $25^{\circ} \mathrm{C}$; fotofase: 14 horas.

\begin{tabular}{cccc}
\hline $\begin{array}{c}\text { Umidade } \\
(\%)\end{array}$ & $\begin{array}{c}\text { Ciclo de desenvolvimento } \\
\text { (fase móvel - adulto) }\end{array}$ & $\begin{array}{c}\text { Longevidade } \\
\text { (adulto) }\end{array}$ & $\begin{array}{c}\text { Ciclo de vida } \\
\text { (fase móvel - morte do adulto) }\end{array}$ \\
\hline 30 & $41,30 \pm 0,85 \mathrm{a}$ & $66,17 \pm 4,83 \mathrm{ab}$ & $107,46 \pm 4,46 \mathrm{a}$ \\
$(41-42)$ & $(62-69)$ & $(104-110)$ \\
50 & $35,00 \pm 1,38 \mathrm{c}$ & $59,59 \pm 2,93 \mathrm{~b}$ & $94,68 \pm 2,64 \mathrm{~b}$ \\
& $(34-35)$ & $(57-61)$ & $(93-96)$ \\
70 & $29,52 \pm 1,05 \mathrm{~d}$ & $72,16 \pm 3,50 \mathrm{a}$ & $101,68 \pm 3,52 \mathrm{ab}$ \\
& $(29-30)$ & $(69-74)$ & $(99-104)$ \\
90 & $35,58 \pm 1,39 \mathrm{~b}$ & $61,94 \pm 4,64 \mathrm{ab}$ & $97,50 \pm 4,72 \mathrm{ab}$ \\
& $(35-36)$ & $(58-65)$ & $(94-101)$ \\
\hline
\end{tabular}

Médias seguidas de letras diferentes, na vertical, diferem estatisticamente entre si, pelo teste de Duncan, ao nível de $5 \%$ de probabilidade;

Valores entre parênteses expressam o intervalo de variação, ao nivel de $5 \%$ de probabilidade. 
Tabela 22. Duração média da geração $(T)$, taxa líquida de reprodução $\left(\mathrm{R}_{\mathrm{o}}\right)$, razão infinitesinmal de aumento $\left(\mathrm{r}_{\mathrm{m}}\right)$ e razão finita de aumento $(\lambda)$ para $S$. articulatus em diferentes umidades. Temperatura: $25^{\circ} \mathrm{C}$; fotofase 14 horas.

\begin{tabular}{ccccc}
\hline $\begin{array}{c}\text { Umidade } \\
(\%)\end{array}$ & $\mathrm{R}_{\mathrm{o}}$ & $\mathrm{T}$ & $\mathrm{r}_{\mathrm{m}}$ & $\lambda$ \\
\hline 30 & 6,89 & 92,16 & 0,0209 & 1,0219 \\
50 & 15,64 & 77,62 & 0,0354 & 1,0373 \\
70 & 18,91 & 74,38 & 0,0395 & 1,0418 \\
90 & 13,42 & 77,89 & 0,0333 & 1,0351 \\
\hline
\end{tabular}

Considerando-se que a melhor faixa de temperatura para $S$. articulatus situa-se entre 25 e $28^{\circ} \mathrm{C}$ e que a melhor umidade relativa para esta espécie é a de $70 \%$, é importante considerar que, embora nas temperaturas mais elevadas, ocorra o maior número de gerações, é necessário que tais regiões tenham períodos de UR superiores a $70 \%$, para que o desenvolvimento da praga seja favorecido. Tais condições de UR são menos freqüentes nas regiões mais quentes como Barretos, Araraquara e Bebedouro, que têm, com base nas normais climatológicas, apenas os meses de janeiro, janeiro-fevereiro e janeiro-fevereiro-março, respectivamente, com UR acima de $70 \%$, enquanto que São José do Rio Preto e Limeira têm, de janeiro a julho, umidades relativas superiores a $70 \%$, condições que favorecem o desenvolvimento da praga. Por outro lado, considerando-se que a faixa de $50-70 \%$ UR permite o desenvolvimento da cochonilha, realmente nas áreas mais quentes, há possibilidade de maior crescimento da população da praga, pois das cinco regiões citrícolas de São Paulo (Barretos, Araraquara, Limeira, São José do Rio Preto e Bebedouro), apenas em agosto - setembro, na região de Barretos, ocorrem UR médias inferiores a 50\% (Garcia, 1998). Como em tal análise foram considerados dados macroclimáticos, sugerem-se estudos da comprovação deste modelo (hipótese) com base em dados microclimáticos. 


\subsection{Biologia comparada de $S$. articulatus em variedades de Citrus e em Citrullus silvestris}

A duração das fases de desenvolvimento de fềmeas foi significativamente afetada pelos genótipos avaliados (Tabela 23). No primeiro ínstar, a variedade 'Hamlin' propiciou a menor duração (11,57 dias), havendo um alongamento considerável desta fase em C. silvestris (em torno de 21 dias). Entre estes valores extremos, situaram-se as variedades 'Pera' com 12,91, 'Natal' com 15,18 e 'Valência' com 19,51 dias (Tabela 23). Para o segundo ínstar, constatou-se tendência semelhante ao primeiro, sendo a duração em torno de 15 dias nas variedades 'Hamlin' e 'Pera'. Entretanto, a maior duração foi verificada em 'Valência' (Tabela 23). Portanto, para os dois ínstares, o

melhor desenvolvimento se deu em 'Hamlin', ficando 'Natal' e 'Pera' numa posição intermediária. Como conseqüência, o ciclo total (fase móvel-adulto) de fêmeas de $S$. articulatus foi menor em 'Hamlin' com 26,54 dias, e o mais longo período em 'Valência' e C. silvestris (Tabela 23).

No caso dos machos, também foram constatadas diferenças significativas, seguindo a mesma tendência observada para as fêmeas (Tabela 24). Os dois primeiros ínstares foram os mais longos em todas as variedades, com diferenças acentuadas entre elas. Para o terceiro e quarto ínstares, as durações foram menores, o que levou também a menores diferenças entre diferentes hospedeiros. Houve encurtamento do ciclo de machos em 'Hamlin', sendo o maior período observado em C. silvestris. A tendência, nas demais variedades, foi igual aos resultados obtidos para fềmeas (Tabelas 23 e 24).

A viabilidade foi diferente entre as variedades, para fêmeas de $S$. articulatus, ocorrendo tal diferenciação no primeiro ínstar. A menor mortalidade de ninfas móveis ocorreu em 'Hamlin', havendo maior dificuldade de fixação em 'Valência'. Após 'Hamlin', as menores mortalidades foram observadas em 'Pera', 'Natal' e C. silvestris, em seqüência (Tabela 25). Nos demais ínstares, a mortalidade foi semelhante nos diferentes hospedeiros (Tabela 25). 
Tabela 23. Duração (dias) das fases imaturas e do ciclo total (fase móvel - adulto) de fềmeas de $S$. articulatus em 4 variedades de laranja e C. silvestris. Temperatura: $25 \pm 2^{\circ} \mathrm{C}$; UR: $60 \pm 10 \%$; fotofase: 14 horas.

\begin{tabular}{|c|c|c|c|}
\hline Hospedeiro & $\begin{array}{c}1^{\mathcal{Q}} \text { instar } \\
\text { (fase móvel }+ \text { fase fixa) }\end{array}$ & $\begin{array}{l}2^{0} \text { instar } \\
\text { (ninfa 2) }\end{array}$ & Ciclo total \\
\hline 'HAMLIN' & $\begin{array}{c}11,57 \pm 1,71 \mathrm{e} \\
(11-12)\end{array}$ & $\begin{array}{c}14,98 \pm 0,91 d \\
(14-15)\end{array}$ & $\begin{array}{c}26,54 \pm 1,01 d \\
(26-27)\end{array}$ \\
\hline 'NATAL' & $\begin{array}{c}15,58 \pm 1,25 c \\
(15-16)\end{array}$ & $\begin{array}{c}17,19 \pm 0,93 c \\
(17-18)\end{array}$ & $\begin{array}{c}32,88 \pm 1,29 b \\
(32-33)\end{array}$ \\
\hline 'PERA' & $\begin{array}{c}12,91 \pm 1,03 d \\
(12-13)\end{array}$ & $\begin{array}{c}15,23 \pm 0,92 d \\
(28-29)\end{array}$ & $\begin{array}{c}28,37 \pm 1,06 c \\
(28-29)\end{array}$ \\
\hline 'VALÊNCIA' & $\begin{array}{c}19,51 \pm 1,67 b \\
(19-20)\end{array}$ & $\begin{array}{c}21,20 \pm 1,07 a \\
(21-22)\end{array}$ & $\begin{array}{c}40,72 \pm 1,44 a \\
(40-41)\end{array}$ \\
\hline C. silvestris & $\begin{array}{c}20,85 \pm 1,77 a \\
(20-21)\end{array}$ & $\begin{array}{c}20,43 \pm 0,93 b \\
(20-21)\end{array}$ & $\begin{array}{c}41,20 \pm 1,97 a \\
(41-42)\end{array}$ \\
\hline
\end{tabular}

Médias seguidas de letras diferentes, na vertical, diferem estatisticamente entre si, pelo teste de Duncan, ao nivel de $5 \%$ de probabilidade;

Valores entre parênteses expressam o intervalo de variação, ao nivel de $5 \%$ de probabilidade.

Para machos, além da variação na fixação, houve diferença na viabilidade do último ínstar, ocorrendo maior mortalidade em 'Valência', embora sem diferir de $C$. silvestris (Tabela 26).

O desenvolvimento de $S$. articulatus em $C$. silvestris, apesar de mais longo do que aquele observado em variedades de Citrus, foi semelhante a tais genótipos com relação à viabilidade. Bartra (1974) constatou que a fecundidade foi maior em $C$. silvestris do que em frutos de limão, para S. articulatus. Marín \& Cisneros (1982) observaram, para Pinnaspis aspidistrae (Sing.) e P. strachani (Cooley), que o hospedeiro selvagem (C. silvestris) promoveu um alongamento no desenvolvimento das cochonilhas, em relação a frutos de laranja e mudas de tangerineira. Por outro lado, o número de ovos foi maior para cochonilhas criadas em $C$. silvestris, demonstrando ser 
este o melhor hospedeiro para criação. A mortalidade no ciclo total, de machos e fềmeas, foi ao redor de $60-65 \%$ (Figura 26 ).

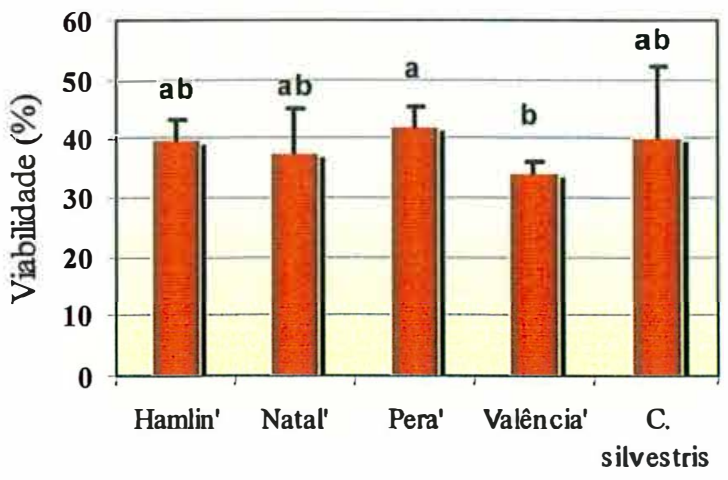

A

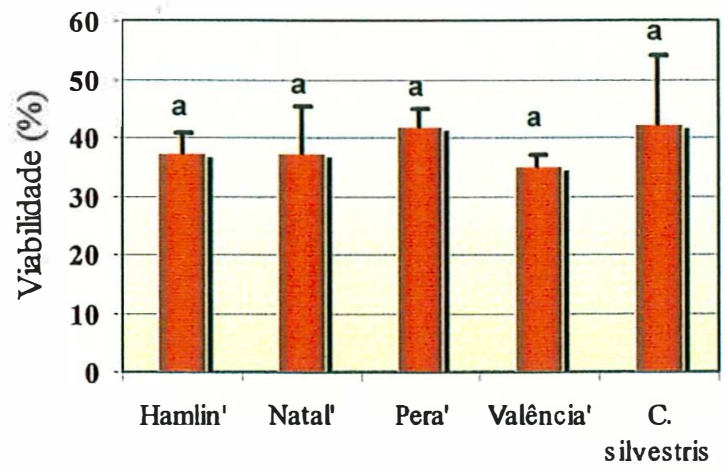

B

Figura 26. Viabilidade (\%) do ciclo total (fase móvel - adulto) de fêmeas (A) e machos (B) de S. articulatus sobre frutos de Citrus e C. silvestris. Temperatura: $25 \pm$ $2^{\circ} \mathrm{C}$; UR: $60 \pm 10 \%$; fotofase: 14 horas. Barras seguidas das mesmas letras não diferem significativamente pelo teste de Ducan a $5 \%$.

Com respeito à duração e viabilidade constatadas no presente trabalho para as variedades de Citrus, observou-se que 'Hamlin' comportou-se como a mais adequada, 'Pera' e 'Natal', como intermediárias e 'Valência', como menos propícia ao desenvolvimento de $S$. articulatus. Isto provavelmente se deva à espessura e à textura da casca, observando-se que 'Hamlin' e 'Pera' apresentam uma casca fina com superfície lisa, 'Natal' apresenta uma casca de espessura fina a média e em 'Valência', a casca é espessa e cheia de rugosidades na superfície (González-Sicilia, 1960; Rodriguez et al., 1991). As características relacionadas à casca interferem diretamente na capacidade de inserção das peças bucais na superfície dos frutos, isto é, a cochonilha insere os seus estiletes bucais com maior facilidade em frutos que apresentam casca fina e lisa. 
Tabela 24. Duração (dias) das fases imaturas e do ciclo total (fase móvel - adulto) de machos de $S$. articulatus em 4 variedades de laranja e C. silvestris. Temperatura: $25 \pm 2^{\circ} \mathrm{C}$; UR: $60 \pm 10 \%$; fotofase: 14 horas.

\begin{tabular}{|c|c|c|c|c|c|}
\hline Hospedeiro & $\begin{array}{c}1^{0} \text { instar } \\
\text { (fase móvel }+ \\
\text { fase fixa) }\end{array}$ & $\begin{array}{l}2^{\circ} \text { instar } \\
\text { (ninfia 2) }\end{array}$ & $\begin{array}{c}3^{\circ} \text { ínstar } \\
\text { ("pré-pupa") }\end{array}$ & $\begin{array}{l}4^{\circ} \text { instar } \\
\text { ("pupa") }\end{array}$ & $\begin{array}{l}\text { Ciclo } \\
\text { total }\end{array}$ \\
\hline 'HAMLIN' & $\begin{array}{c}10,40 \pm 0,85 d \\
(10-11)\end{array}$ & $\begin{array}{c}7,49 \pm 0,91 \mathrm{c} \\
(7-8)\end{array}$ & $\begin{array}{c}3,65 \pm 0,47 d \\
(3-4)\end{array}$ & $\begin{array}{c}4,20 \pm 0,64 d \\
(4-5)\end{array}$ & $\begin{array}{c}25,42 \pm 1,02 \mathrm{e} \\
(25-26)\end{array}$ \\
\hline 'NATAL' & $\begin{array}{c}12,91 \pm 1,41 \mathrm{c} \\
(12-13)\end{array}$ & $\begin{array}{c}10,58 \pm 0,68 \\
b(10-11)\end{array}$ & $\begin{array}{c}4,62 \pm 0,49 a \\
(4-5)\end{array}$ & $\begin{array}{c}4,66 \pm 0,51 b c \\
(4-5)\end{array}$ & $\begin{array}{c}31,83 \pm 0,65 c \\
(31-32)\end{array}$ \\
\hline 'PERA' & $\begin{array}{c}10,74 \pm 1,01 d \\
(10-11)\end{array}$ & $\begin{array}{c}7,04 \pm 0,77 d \\
(7-8)\end{array}$ & $\begin{array}{c}4,66 \pm 0,77 a \\
(4-5)\end{array}$ & $\begin{array}{c}4,46 \pm 0,53 \mathrm{c} \\
(4-5)\end{array}$ & $\begin{array}{c}26,84 \pm 1,20 d \\
(26-27)\end{array}$ \\
\hline 'VALÊNCIA' & $\begin{array}{c}16,66 \pm 2,04 b \\
(16-17)\end{array}$ & $\begin{array}{c}14,93 \pm 0,98 \\
a(14-15)\end{array}$ & $\begin{array}{c}4,02 \pm 0,53 c \\
(4-5)\end{array}$ & $\begin{array}{c}4,91 \pm 0,57 \mathrm{a} \\
(4-5)\end{array}$ & $\begin{array}{c}38,94 \pm 1,04 b \\
(38-39)\end{array}$ \\
\hline C. silvestris & $\begin{array}{c}17,31 \pm 1,65 a \\
(17-18)\end{array}$ & $\begin{array}{c}14,93 \pm 1,01 \\
\text { a }(14-15)\end{array}$ & $\begin{array}{c}4,34 \pm 0,51 b \\
(4-5)\end{array}$ & $\begin{array}{c}4,71 \pm 0,45 a b \\
(4-5)\end{array}$ & $\begin{array}{c}40,50 \pm 1,37 a \\
(40-41)\end{array}$ \\
\hline
\end{tabular}

Médias seguidas de letras diferentes, na vertical, diferem estatisticamente entre si, pelo teste de Duncan, ao nível de $5 \%$ de probabilidade;

Valores entre parênteses expressam o intervalo de variação, ao nível de $5 \%$ de probabilidade.

Tabela 25. Viabilidade (\%) da fase móvel (fixação), das fases imaturas de fềmeas de $S$. articulatus em 4 variedades de laranja e C. silvestris. Temperatura: $25 \pm$ $2^{\circ} \mathrm{C}$; UR: $60 \pm 10 \%$; fotofase: 14 horas.

\begin{tabular}{ccccc}
\hline Hospedeiro & $\mathrm{n}^{*}$ & \multicolumn{3}{c}{ Viabilidade (\%) } \\
\cline { 3 - 6 } & $\begin{array}{c}1^{\mathrm{O}} \text { ínstar } \\
\text { (ninfas móveis - fixação) }\end{array}$ & $\begin{array}{c}1^{\mathbf{0}} \text { instar } \\
\text { (ninfas fixas) }\end{array}$ & $\begin{array}{c}2^{\mathbf{0}} \text { instar } \\
\text { (ninfa 2) }\end{array}$ \\
\hline 'HAMLIN' & 50 & $85,50 \pm 3,00 \mathrm{a}$ & $46,89 \pm 4,31 \mathrm{a}$ & $96,30 \pm 4,60 \mathrm{a}$ \\
'NATAL' & 50 & $57,50 \pm 1,00 \mathrm{~d}$ & $40,05 \pm 7,05 \mathrm{a}$ & $97,37 \pm 10,98 \mathrm{a}$ \\
'PERA' & 50 & $75,00 \pm 3,82 \mathrm{~b}$ & $48,47 \pm 8,26 \mathrm{a}$ & $92,48 \pm 5,02 \mathrm{a}$ \\
'VALÊNCIA' & 50 & $48,50 \pm 2,51 \mathrm{e}$ & $38,23 \pm 2,95 \mathrm{a}$ & $94,44 \pm 6,41 \mathrm{a}$ \\
C. silvestris & 50 & $64,50 \pm 4,12 \mathrm{c}$ & $48,38 \pm 6,92 \mathrm{a}$ & $93,32 \pm 5,45 \mathrm{a}$ \\
\hline
\end{tabular}

Médias seguidas de letras diferentes, na vertical, diferem estatisticamente entre si, pelo teste de Duncan, ao nível de $5 \%$ de probabilidade;

*Número de ninfas móveis analisadas;

**Não há possibilidade de separação de sexos nessa fase de desenvolvimento da cochonilha; 
C. silvestris é uma planta selvagem, não comestivel, utilizada como hospedeiro alternativo para criação massal de cochonilhas da família Diaspididae (Bartra, 1994). No presente trabalho, constatou-se que a duração do fruto, em condições de laboratório, é de três meses a um ano, dependendo do estágio de desenvolvimento em que é colhido. Frutos de menor tamanho tendem a durar menos do que frutos grandes. Quando comparado a frutos de Citrus, que não duram mais do que um mês e meio, e às mudas de Citrus, cuja obtenção e manipulação são trabalhosas, observa-se que a criação no hospedeiro alternativo é vantajosa, aliado à sua maior área infestável, possibilitando maior número de cochonilhas e gerações, favorecendo a multiplicação do inseto e facilitando a produção de parasitóides e predadores.

Tabela 26. Viabilidade (\%) da fase móvel (fixação), das fases imaturas de machos de $S$. articulatus em 4 variedades de laranja e C. silvestris. Temperatura: $25 \pm$ $2^{\circ} \mathrm{C}$; UR: $60 \pm 10 \%$; fotofase: 14 horas.

\begin{tabular}{ccccccc}
\hline & & \multicolumn{5}{c}{ Viabilidade (\%) } \\
\cline { 2 - 7 } Hospedeiro & $\mathrm{n}^{*}$ & $\begin{array}{c}1^{\circ} \text { ínstar } \\
\text { (ninfas móveis } \\
\text { - fixação) }\end{array}$ & $\begin{array}{c}1^{\circ} \text { '́nstar } \\
\text { (ninfas fixas) }\end{array}$ & $\begin{array}{c}2^{\circ} \text { instar } \\
\text { (ninfa 2) }\end{array}$ & $\begin{array}{c}3^{\circ} \text { ínstar } \\
\text { ("pré-pupa") }\end{array}$ & $\begin{array}{c}4^{\circ} \text { ínstar } \\
\text { ("pupa") }\end{array}$ \\
\hline 'HAMLIN' & 50 & $85,50 \pm 3,00 \mathrm{a}$ & $49,00 \pm 5,36 \mathrm{a}$ & $91,76 \pm 3,90 \mathrm{a}$ & $98,63 \pm 8,17 \mathrm{a}$ & $96,74 \pm 6,52 \mathrm{a}$ \\
'NATAL' & 50 & $57,50 \pm 1,00 \mathrm{~d}$ & $51,32 \pm 4,55 \mathrm{a}$ & $93,18 \pm 0,61 \mathrm{a}$ & $90,89 \pm 8,96 \mathrm{a}$ & $96,91 \pm 9,99 \mathrm{a}$ \\
'PERA' & 50 & $75,00 \pm 3,82 \mathrm{~b}$ & $46,86 \pm 46,86 \mathrm{a}$ & $98,81 \pm 2,38 \mathrm{a}$ & $95,44 \pm 5,38 \mathrm{a}$ & $98,75 \pm 2,50 \mathrm{a}$ \\
'VALÊNCIA' & 50 & $48,50 \pm 2,51 \mathrm{e}$ & $51,38 \pm 5,50 \mathrm{a}$ & $91,85 \pm 20,38 \mathrm{a}$ & $88,88 \pm 7,85 \mathrm{a}$ & $85,20 \pm 4,42 \mathrm{~b}$ \\
C. silvestris & 50 & $64,50 \pm 4,12 \mathrm{c}$ & $48,55 \pm 6,48 \mathrm{a}$ & $96,82 \pm 3,82 \mathrm{a}$ & $95,80 \pm 5,14 \mathrm{a}$ & $91,94 \pm 5,97 \mathrm{ab}$
\end{tabular}

Médias seguidas de letras diferentes, na vertical, diferem estatisticamente entre si, pelo teste de Duncan, ao nível de $5 \%$ de probabilidade;

*Número de ninfas móveis analisadas;

**Não há possibilidade de separação de sexos nessa fase de desenvolvimento da cochonilha; 
Razão sexual: não foi observada diferença significativa para essa variável, sendo os sexos igualmente afetados pelas variedades. A razão sexual para $S$. articulatus foi sempre próxima a 0,5 , à semelhança dos resultados obtidos para temperatura e umidade relativa (itens 4.2.1.2 e 4.4) (Tabela 27).

Tabela 27. Relação sexual e razão sexual de $S$. articulatus em 4 variedades de laranja e C. silvestris. Temperatura: $25 \pm 2{ }^{\circ} \mathrm{C}$; UR: $60 \pm 10 \%$; fotofase: 14 horas.

\begin{tabular}{cccc}
\hline Hospedeiro & $\mathrm{n}^{*}$ & $\begin{array}{c}\text { Relação } \\
\text { sexual }\end{array}$ & $\begin{array}{c}\text { Razão } \\
\text { sexual }\end{array}$ \\
\hline 'HAMLIN' & 164 & $0,95: 1$ & 0,49 I \\
'NATAL' & 105 & $0,78: 1$ & 0,44 I \\
'PERA' & 143 & $1,00: 1$ & 0,51 I \\
'VALÊNCIA' & 87 & $0,74: 1$ & 0,43 I \\
C. silvestris & 125 & $0,96: 1$ & 0,50 I
\end{tabular}

Médias seguidas do mesmo algarismo romano, não diferem entre si, pelo teste Qui-quadrado, ao nível de $5 \%$ de probabilidade.

*Número de adultos.

\subsection{Efeito da idade da folha na fixação de $S$. articulatus}

Constataram-se diferenças significativas quanto à fixação das cochonilhas, observando-se, claramente, a preferência por folhas novas (26\%). Nas folhas maduras, praticamente, elas não se estabeleceram (2\%) e nas folhas médias, o valor foi intermediário (8\%) (Tabela 28 e Figura 27). As cochonilhas que não se fixaram ao substrato $(64 \%)$ foram encontradas dispersas na placa de Petri ou mortas. Esse valor está bastante próximo da mortalidade de ninfas móveis observada no presente experimento, para os estudos sobre os efeitos da temperatura e umidade (itens 4.2.1.1 e 4.4). 
No presente trabalho, em todos os casos, constatou-se a ocorrência do inseto ao longo das nervuras foliares (principal e secundárias), o que não coincide com as observações de Pinto (1995), que referiu que, em campo, as cochonilhas preferem a parte basal das folhas (mais próximas ao pecíolo). Possivelmente, em campo, haja sobreposição de gerações da cochonilha, levando à uma alta população, o que as levaria a ocupar toda a superficie da folha, não permitindo a fixação somente num local determinado.

Tabela 28. Número médio de $S$. articulatus em folhas de $C$. limonia, em três estágios de desenvolvimento. Temperatura: $25 \pm 2^{\circ} \mathrm{C}$; UR: $60 \pm 10 \%$; fotofase: 14 horas.

\begin{tabular}{ccc}
\hline Estágio de desenvolvimento & $\mathrm{n}^{\mathbf{*}}$ & Fixação $\left(\mathrm{n}^{\mathbf{0}}\right)$ \\
\hline FOLHAS NOVAS & 50 & $\begin{array}{c}13,06 \pm 1,83 \mathrm{a} \\
(12-14)\end{array}$ \\
FOLHAS MÉDIAS & 50 & $4,13 \pm 1,50 \mathrm{~b}$ \\
& & $(3-5)$ \\
FOLHAS MADURAS & 50 & $1,00 \pm 1,00 \mathrm{c}$ \\
& & $(0,44-1,55)$
\end{tabular}

Médias seguidas de letras diferentes, na vertical, diferem estatisticamente entre si, pelo teste de Duncan, ao nivel de $5 \%$ de probabilidade.

Valores entre parênteses expressam o intervalo de variação, ao nível de $5 \%$ de probabilidade.

*Número de ninfas móveis analisadas.

Os resultados obtidos permitem concluir que $S$. articulatus não prefere folhas maduras, discordando da literatura (Herrera Aranguena, 1964; Gravena, 1990; Ferraz, 1997), que relatam a infestação dessa cochonilha em folhas maduras cobertas de poeira, em condições de campo. Na verdade, a poeira não tem nenhuma influência na reprodução da cochonilha, apenas protegendo-a de parasitóides e de inseticidas 
(observação pessoal). Em relação à idade das folhas, em pomares, as cochonilhas podem permanecer fixadas às folhas por muito tempo depois de completado o seu ciclo de desenvolvimento, uma vez que a duração das folhas nas plantas cítricas varia de um a três anos (Rodriguez et al., 1991). Entretanto, o que ocorre é que as cochonilhas que se encontram nessas folhas maduras, na grande parte dos casos, estão mortas.

Os resultados obtidos sugerem que criações de $S$. articulatus, em laboratório, devem ser feitas em folhas novas de mudas cítricas, o que facilita bastante a sua manipulação, e sobretudo, permitem estudos ocupando espaços menores.

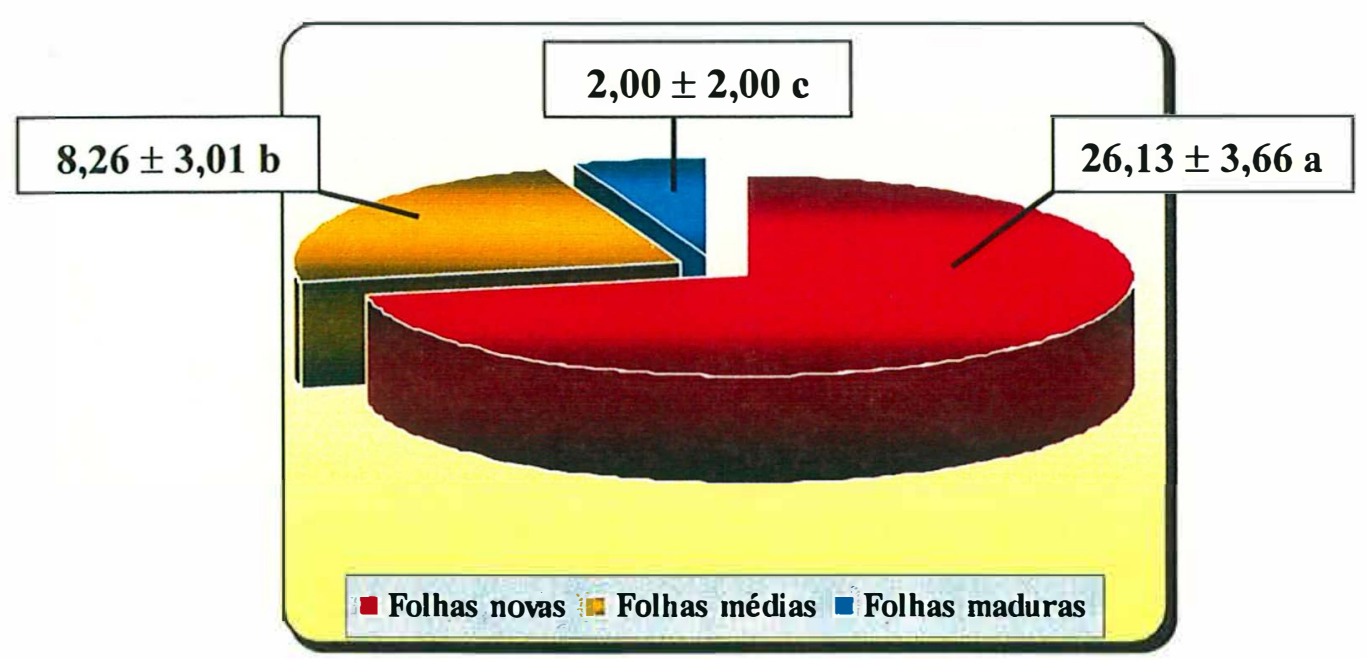

Figura 27. Porcentagem de fixação de $S$. articulatus em folhas de $C$. limonia, em três estágios de desenvolvimento. Temperatura: $25 \pm 2{ }^{\circ} \mathrm{C}$; UR: $60 \pm 10 \%$; fotofase: 14 horas. 


\subsection{Determinação do nível de controle de $S$. articulatus com base na redução de parâmetros fisiológicos}

\subsubsection{Escala diagramática}

Baseando-se na escala diagramática, elaborada para a avaliação de danos (severidade) de $S$. articulatus, com sete níveis de severidade $(0,5 ; 1,3 ; 3,0 ; 7,0 ; 15,0$; 25,0 e 35,0), em folhas de C. limonia de tamanho médio (Figura 5), pôde-se observar que ocorreram diferenças entre a avaliação visual (e resíduos) e valores reais de severidade (danos) para cada avaliador (Figuras 28 e 29 ).

As diferenças (para a face adaxial) entre os valores estimados e os valores reais foram consideradas pequenas para níveis de severidade reais inferiores a $10 \%$. Entretanto, quando a severidade real excedia este limite, a diferença observada entre o estimado e o real tendeu a aumentar.

Pela análise de resíduo (Figura 28), pôde-se concluir que o avaliador 1 apresentou baixa acurácia (pontos mal distribuídos ao redor do eixo zero), enquanto que os avaliadores 2 e 3 tiveram uma melhor acurácia. Em relação à precisão das avaliações, os três avaliadores foram pouco precisos (baixos valores de $\mathrm{R}^{2}$ ), principalmente quando a severidade real atingia valores maiores que $10 \%$. O avaliador 1 teve tendência a superestimar, enquanto que o avaliador 2 subestimou a severidade.

Quanto à avaliação na face abaxial, apesar dos três avaliadores tenderem a subestimar a severidade, a precisão e acurácia das avaliações foram bem melhores (Figura 29).

Para a face adaxial, a acurácia foi melhor para o avaliador 1 , que apresentou o valor de interseç̧ão mais próximo a zero. Por outro lado, os coeficientes angulares dos avaliadores 2 e 3 foram os mais próximos ao valor um, o que indica que estes apresentaram as melhores acurácias. Observando-se os valores de $\mathrm{R}^{2}$ verifica-se que $o$ avaliador 1 apresentou o maior valor, o que indica que este foi o avaliador de maior precisão (Tabela 29). 
Tabela 29. Valores obtidos da regressão linear entre a severidade real de S. articulatus e a severidade observada na face adaxial.

\begin{tabular}{cccc}
\hline Avaliador & Intersecção & Coeficiente angular & $\mathrm{R}^{2}$ \\
1 & 0,55 & 1,49 & 0,81 \\
2 & 1,88 & 0,95 & 0,67 \\
3 & 1,05 & 0,75 & 0,68 \\
\hline
\end{tabular}

Para a face abaxial, a acurácia da intersecção foi melhor para o avaliador 1 , por apresentar valor mais próximo a zero. Os valores do coeficiente angular e $\mathrm{R}^{2}$ para todos os avaliadores foram muito semelhantes entre os três avaliadores, sendo estes valores próximos a um, o que permite concluir que todos eles apresentam boa acurácia e precisão (Tabela 30).

Tabela 30. Valores obtidos da regressão linear entre a severidade real de $S$. articulatus e a severidade observada na face abaxial.

\begin{tabular}{cccc}
\hline Avaliador & Intersecção & Coeficiente angular & $\mathrm{R}^{2}$ \\
1 & 0,69 & 0,75 & 0,83 \\
2 & 1,21 & 0,74 & 0,80 \\
3 & 0,25 & 0,60 & 0,78 \\
\hline
\end{tabular}

A justificativa para a não utilização de escalas diagramáticas na área de Entomologia baseia-se no maior tamanho dos insetos, o que facilita as observações diretas do seu dano. Entretanto, para insetos pequenos em altas populações, tais como cochonilhas, moscas brancas, pulgões e algumas espécies de cigarrinhas, a utilização de tais escalas pode ser importante ferramenta para a quantificação dos danos reais e, portanto, deveriam ser mais utilizadas. 

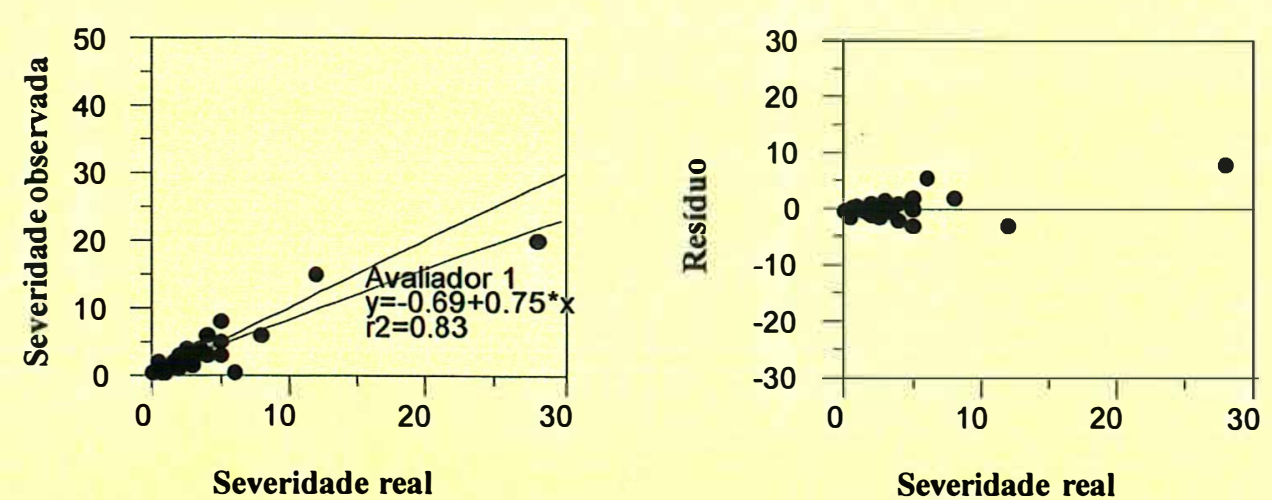

Severidade real
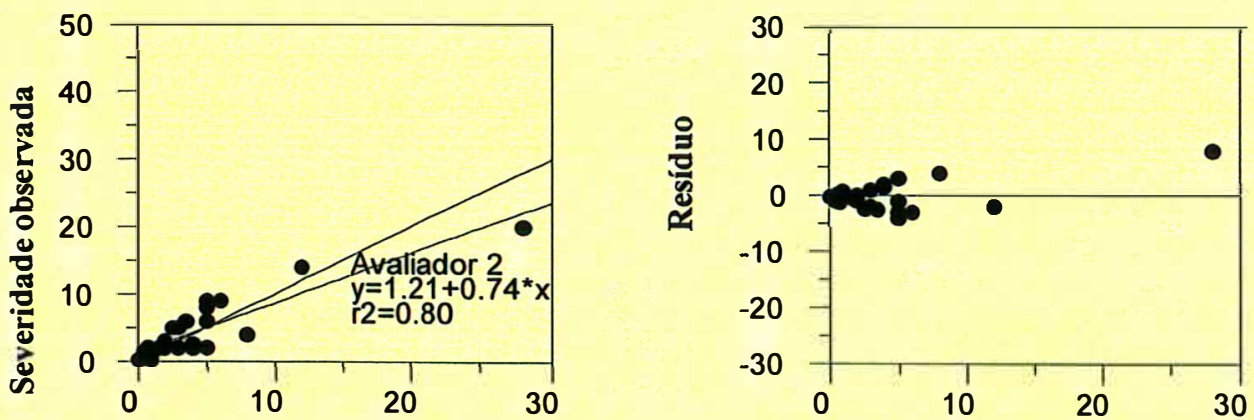

Severidade real
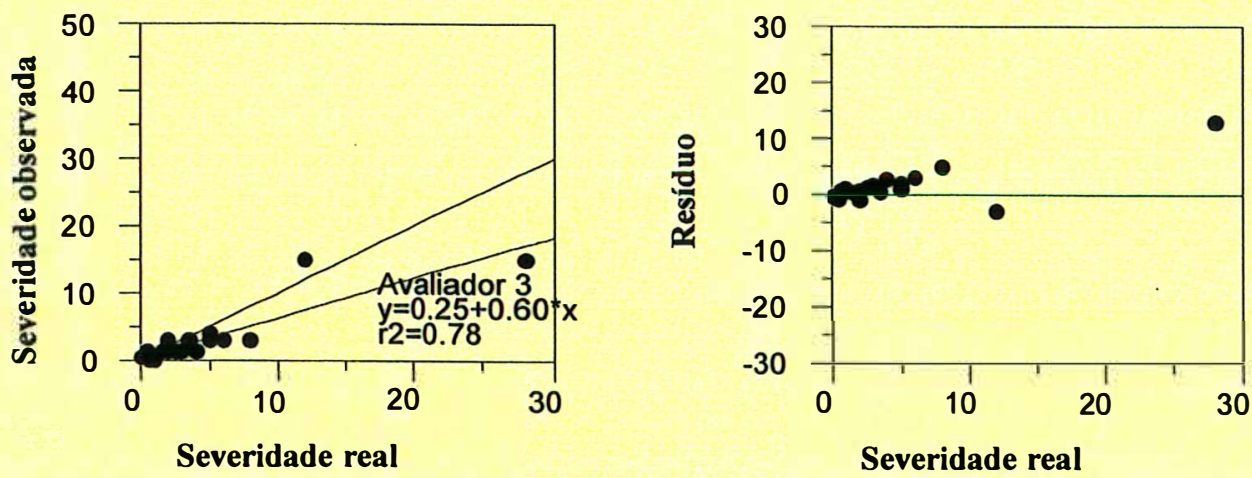

Figura 28. Avaliação da severidade de ataque da cochonilha S. articulatus, na face adaxial da folha de $C$. limonia. 

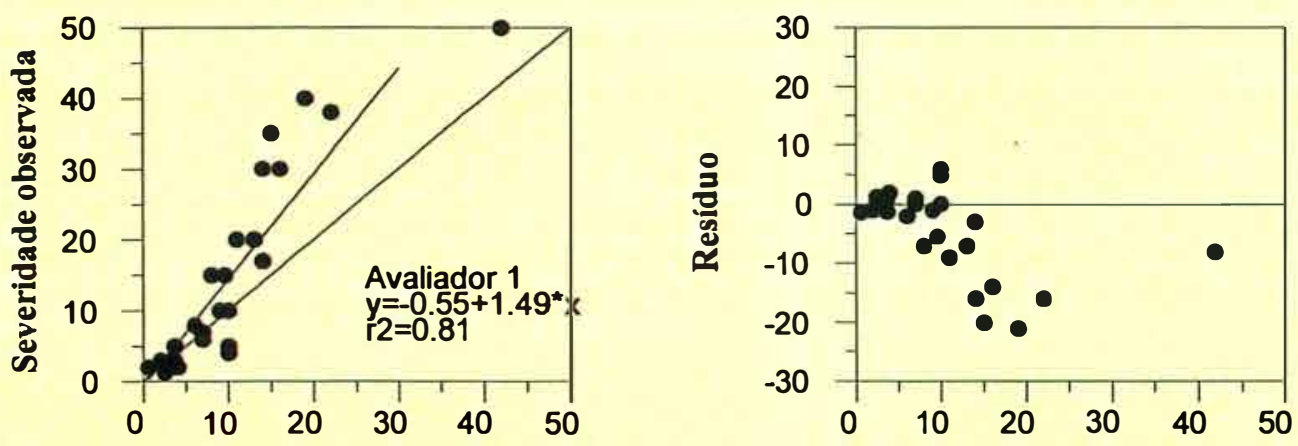

Severidade real
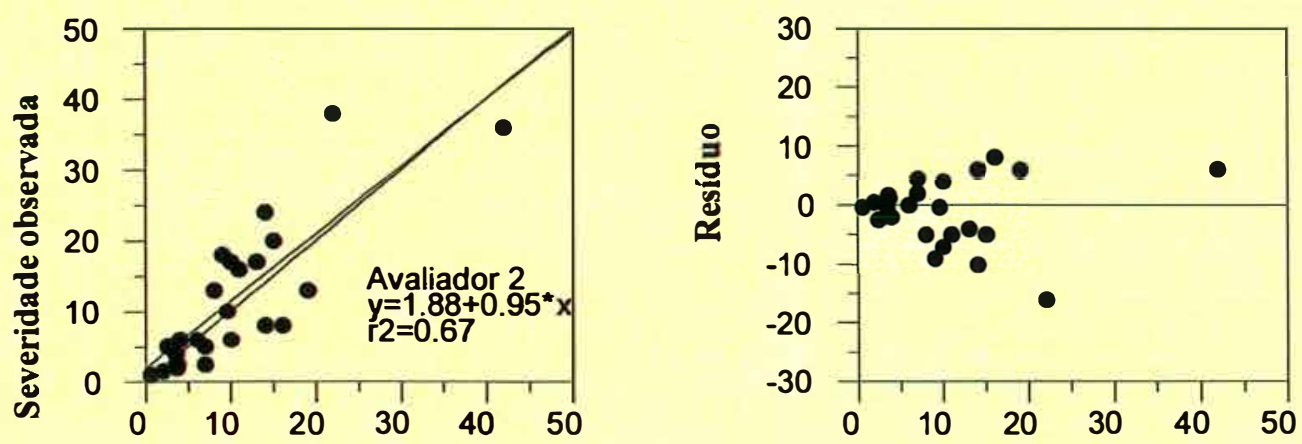

Severidade real

Severidade real
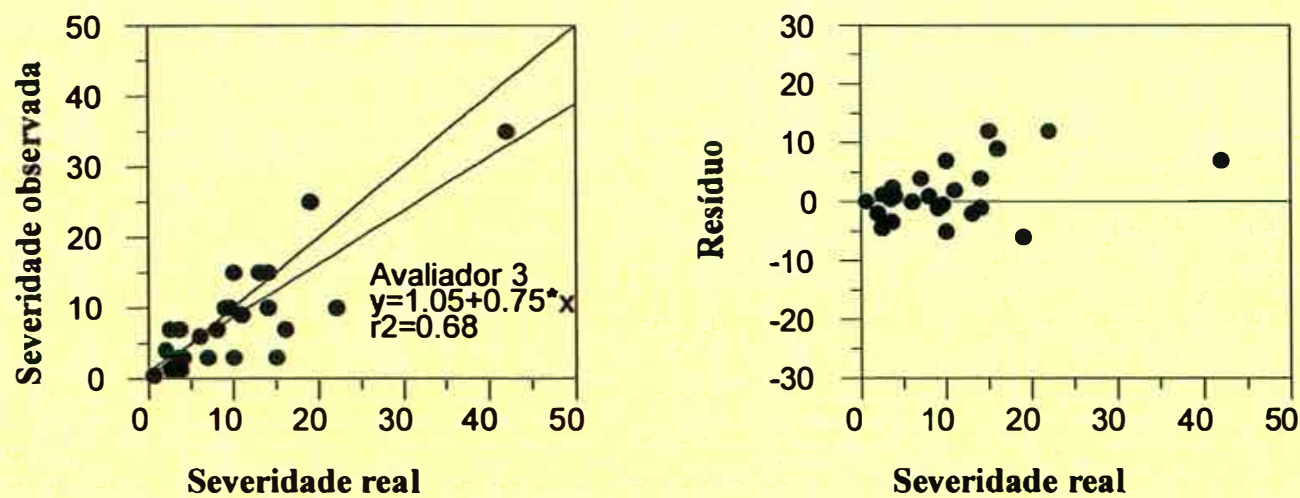

Figura 29. Avaliação da severidade de ataque da cochonilha $S$. articulatus, na face abaxial da folha de C. limonia. 


\subsubsection{Fotossíntese}

Os resultados do ensaio para verificar se a presença das cochonilhas nas folhas afetava a avaliação da fotossíntese, mostraram que os valores obtidos nas folhas com sintomas e com cochonilhas foram semelhantes aos valores obtidos nas folhas com sintomas e sem cochonilhas após a sua remoção (Figura 30). Este resultado pode levar à suposição de que a respiração das cochonilhas não é suficientemente elevada para causar uma diminuição significativa nos valores da taxa fotossintética líquida. Também, podese supor que o dano causado na folha pela cochonilha seja devido ao amarelecimento das regiões com lesões provocadas pela saliva tóxica das cochonilhas, impedindo a absorção da radiação para a fotossíntese. Esta espécie de cochonilha localiza-se na folha ou no fruto de seus hospedeiros e, ao redor do local de penetração dos estiletes, forma-se uma mancha amarela, cujo tamanho aumenta de acordo com o desenvolvimento da cochonilha (Figura 31). Segundo Leite e Pascholati (1995) ao estabelecerem relações alimentares com as plantas que atacam, alguns tipos de insetos e de ácaros, além de causarem danos físicos à planta (relacionados principalmente com a introdução do seu aparato bucal nos tecidos) e de retirarem substâncias da planta, podem também injetar substâncias estranhas nos tecidos da mesma. Tais substâncias, originadas do próprio inseto, são componentes de suas secreções salivares, como amianoácidos, enzimas, etc. Ao serem introduzidas na planta, estas substâncias podem produzir efeito deletério sobre a mesma, constituindo-se, então, em substâncias tóxicas, translocáveis ou não, a curta ou longa distância. $\mathrm{O}$ fenômeno resultante da ação toxicogênica da saliva do inseto nos tecidos da planta é chamado por alguns autores de toxemia ou fitotoxemia.

As toxemias podem ser de ação localizada ou não localizada (sistêmica). As toxemias localizadas manifestam-se como lesões nos pontos de alimentação do inseto toxicogênico. Apresentam-se geralmente como manchas cloróticas ou necróticas, podendo ser causadas por cochonilhas.

Beardsley \& Gonzales (1975) relataram que a presença de clorose nas

folhas e outros efeitos tóxicos estão comumente associados às infestações de cochonilhas da família Diaspididae. Aspidiotus destructor Signoret, por exemplo, 
provocou acentuado amarelecimento das folhas em coqueiro e outras palmáceas. Gonzales (1981) observou, 10 a 12 horas após a fixação de $Q$. perniciosus, a presença de uma mancha vermelha em torno do inseto, em frutos de maçãs e pêssego. Carter $^{3}$ citado por Gonzales (1981), estudou o mecanismo de alimentação de diaspidídeos, determinando que o efeito tóxico é produzido pela ação de dois ou mais componentes presentes na saliva do inseto.

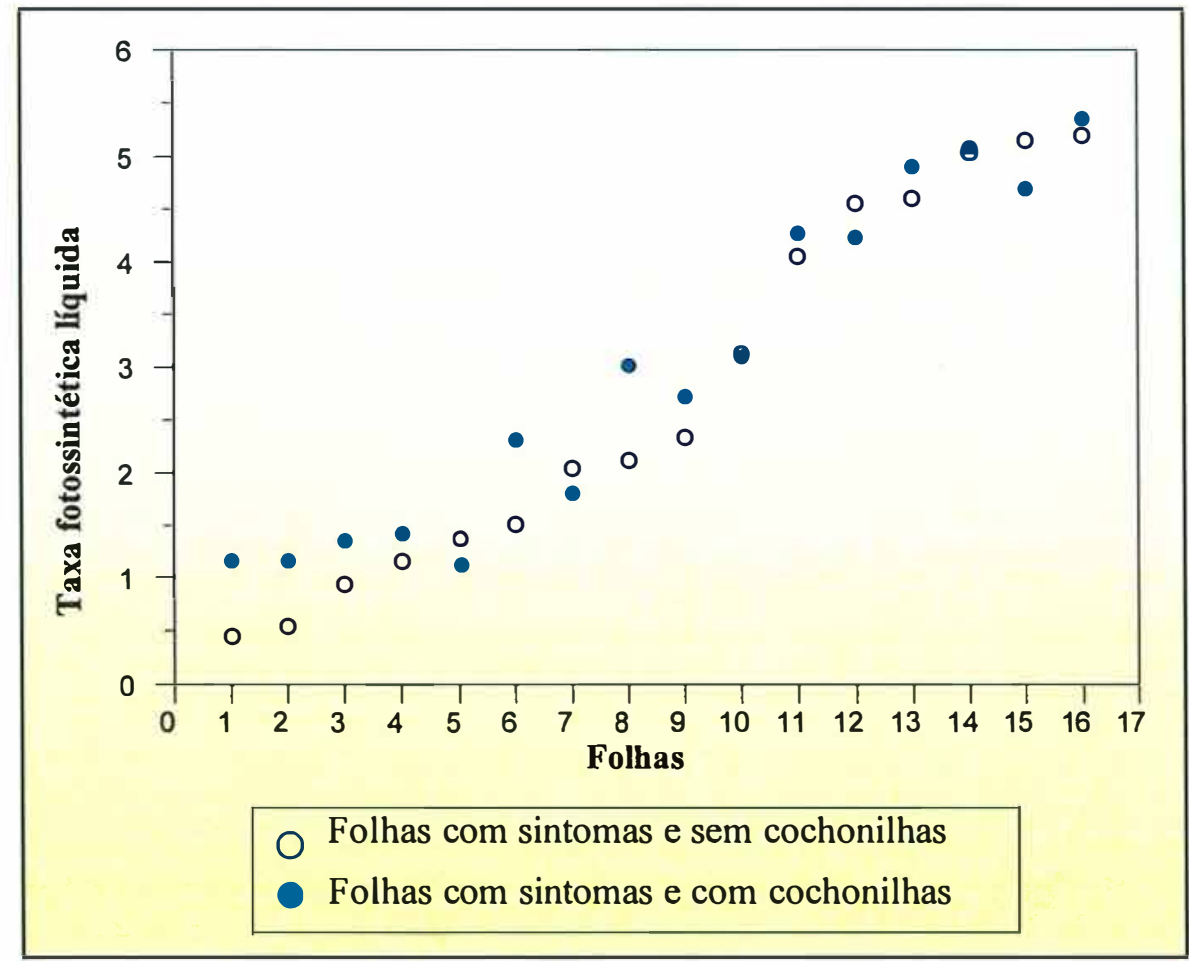

Figura 30. Taxa fotossintética de folhas de C. limonia $\left(\mu \mathrm{mol} \mathrm{CO} 2 \cdot \mathrm{m}^{-2} \cdot \mathrm{s}^{-1}\right)$ com sintomas de ataque de cochonilhas e com sintomas, e sem cochonilhas (elas foram removidas).

$\mathrm{Na}$ presente pesquisa, a fotossíntese deve estar diminuindo, devido ao surgimento de áreas cloróticas ou necrosadas, nas quais ocorre a diminuição das moléculas de clorofila responsáveis pela captação de energia luminosa. Segundo Leite \& Pascholati (1995), na maioria dos casos, a influência dos patógenos sobre a fotossíntese

\footnotetext{
${ }^{3}$ CARTER, W. Insects in relation to plant disease. New York: Interscience, 1962. 705p.
} 
é resultante dos danos causados aos cloroplastos e nos processos de envelhecimento dos tecidos.

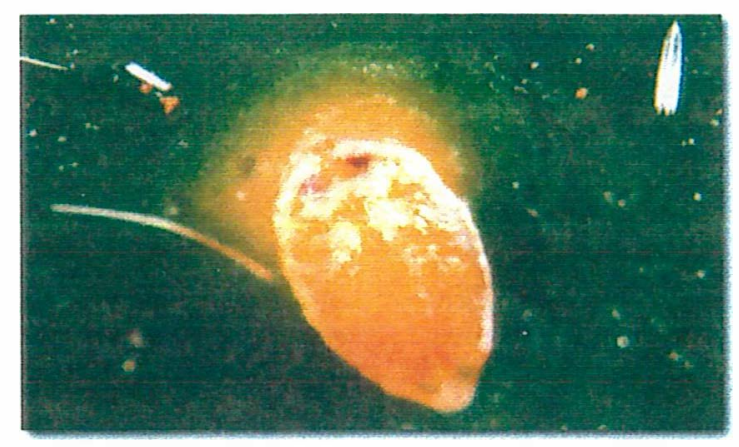

Figura 31. Dano em folha de C. limonia causado pela alimentação e injeção de saliva tóxica de $S$. articulatus no local da picada.

Observou-se que existe uma correlação negativa entre a severidade e a fotossíntese relativa, isto é, quanto maior a severidade de ataque de $S$. articulatus, menor a fotossíntese relativa (Figura 32). Porém, esta relação não é linear e pode ser expressa pelo modelo de Baastians (1991). O parâmetro $\beta$ estimado em 5,79, indica que o ataque das cochonilhas reduz a eficiência fotossintética não apenas no tecido lesionado (áreas cobertas pelas cochonilhas e áreas amareladas), mas também em parte do tecido verde remanescente das folhas infectadas. Este efeito pôde ser observado independentemente da função matemática, uma vez que a taxa fotossintética líquida da folha foi reduzida em torno de $50 \%$ para uma severidade de $12,5 \%$.

Quanto às variáveis condutância estomática e taxa de transpiração não se notou uma correlação bem definida com a severidade de ataque, ocorrendo alta variação dos valores observados mesmo nas folhas sadias (Figura 32).

Em termos de manejo de pragas, poder-se-ia pensar, em função dos resultados obtidos, que medidas de controle devem ser tomadas quando o nível de severidade das cochonilhas estiver abaixo de $7 \%$ (mais ou menos 30 cochonilhas/folha, em mudas); quando ainda não se tem grandes danos na taxa fotossintética, condutância estomática e taxa de transpiração (Figura 33). Este nível de 7\%, seria, em última análise, o nível de controle (NC) da praga. 


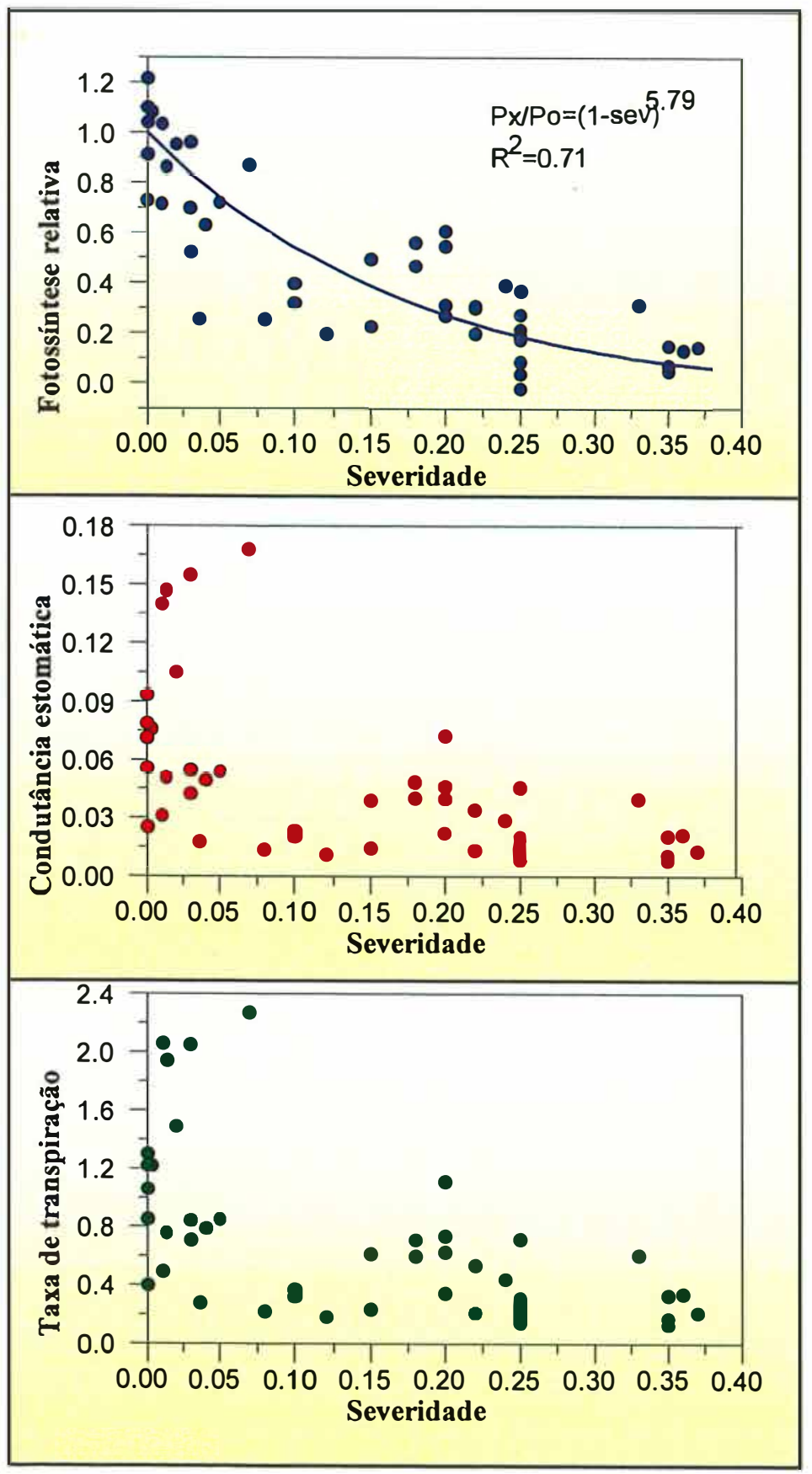

Figura 32. Efeito de S. articulatus na fotossíntese relativa (proporção), condutância estomática $\left(m o l \mathrm{H}_{2} \mathrm{O} \mathrm{m}^{-2} \cdot \mathrm{s}^{-1}\right.$ ) e na taxa de transpiração de folhas (mmol $\left.\mathrm{H}_{2} \mathrm{O} \cdot \mathrm{m}^{-2} \cdot \mathrm{s}^{-1}\right)$ de mudas de $C$. limonia. 


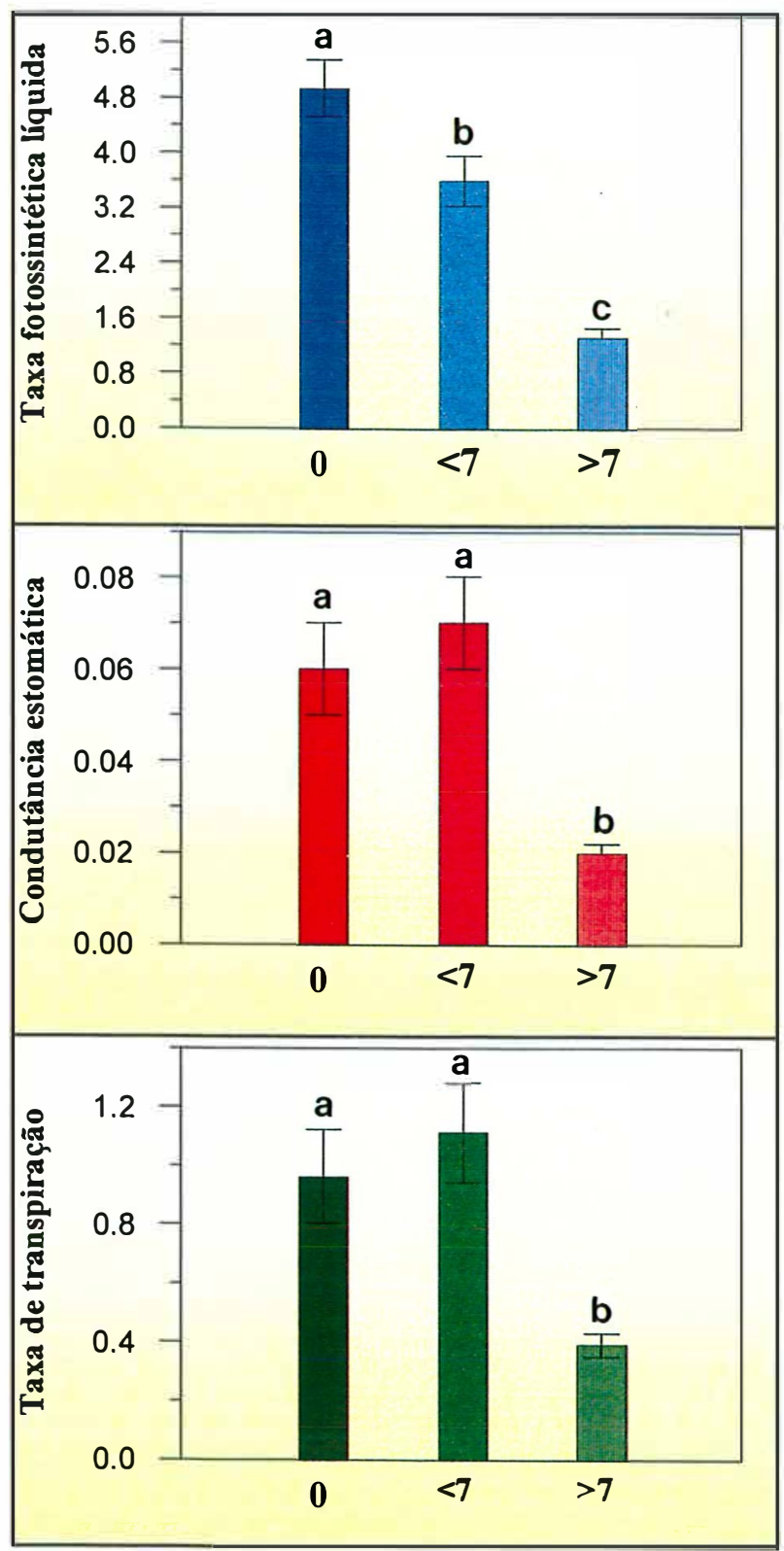

Figura 33. Efeito de níveis de severidade de ataque de $S$. articulatus nas variáveis taxa fotossintética líquida ( $\mu \mathrm{mol} \mathrm{CO}_{2} \cdot \mathrm{m}^{-2} \cdot \mathrm{s}^{-1}$ ), condutância estomática (mol $\mathrm{H}_{2} \mathrm{O} \cdot \mathrm{m}^{-2} \cdot \mathrm{s}^{-1}$ ) e taxa de transpiração (mmol $\left.\mathrm{H}_{2} \mathrm{O} \cdot \mathrm{m}^{-2} \cdot \mathrm{s}^{-1}\right)$. Barras seguidas de mesma letra não diferem entre si pelo teste de Duncan, ao nível de 5\% de probabilidade. 


\section{CONCLUSÕES}

1. Na fase imatura, as fêmeas de Selenaspidus articulatus (Morgan, 1889) têm 2 ínstares (uma fase móvel e um ínstar fixo) e o macho 4 estágios (uma fase móvel e três ínstares fixos);

2. A faixa de desenvolvimento de S. articulatus situa-se entre 18 e $28^{\circ} \mathrm{C}$;

3. Não ocorre desenvolvimento da cochonilha pardinha a $32{ }^{\circ} \mathrm{C}$;

4. A maior fecundidade desta praga se dá entre 25 e $28^{\circ} \mathrm{C}$, sendo o ritmo de postura, nas melhores condições, crescente até os 60 dias;

5. As maiores longevidades de fêmeas são obtidas a $18^{\circ} \mathrm{C}$, sendo semelhantes nas demais condições térmicas;

6. Os machos vivem poucas horas, com maior longevidade a 25 e $28^{\circ} \mathrm{C}$;

7. As maiores taxas líquidas de reprodução $\left(\mathrm{R}_{\mathrm{o}}\right)$ e a razão finita de aumento $(\lambda)$, para $S$. articulatus, ocorrem a 25 e $28^{\circ} \mathrm{C}$;

8. Em função das exigências térmicas, $S$. articulatus pode apresentar um número provável de 6,4 a 9,8 gerações anuais, nas principais áreas citrícolas de São Paulo;

9. A maior fecundidade de S. articulatus ocorre na faixa de UR de 50 a $70 \%$;

10. A umidade relativa do ar mais adequada para $S$. articulatus é a de $70 \%$, com maior fecundidade, longevidade e por proporcionar maior taxa líquida de reprodução $\left(\mathrm{R}_{\mathrm{o}}\right)$ e razão finita de aumento $(\lambda)$;

11. Umidades relativas mais baixas dificultam a fixação de ninfas móveis de $S$. articulatus;

12. Em qualquer condição térmica ou hídrica, a fase crítica para $S$. articulatus é o $1^{\text {o }}$ ínstar, pois neste estágio ocorre maior mortalidade;

13. S. articulatus prefere folhas novas de Citrus limonia para fixação; 
14. 'Hamlin' é preferida pela cochonilha pardinha, quando comparada com as variedades cítricas Natal, Valência e Pera e com a espécie Citrullus silvestris;

15. C. silvestris é considerado hospedeiro adequado para criação de $S$. articulatus, por proporcionar boa viabilidade do inseto e pelo fato do seu fruto apresentar alta durabilidade;

16. Após a fixação, os danos causados pela cochonilha são irreversíveis;

17. O nível de controle de $S$. articulatus é de $7 \%$ de severidade (30 cochonilhas/ folha nova), com base na taxa fotossintética, condutância estomática e taxa de transpiração;

18. O detalhamento da análise morfológica depende da metodologia utilizada na preparação do material para observação em Microscopia Eletrônica de Varredura (MEV). 


\section{REFERÊNCIAS BIBLIOGRÁFICAS}

AMORIN, L.; BERGAMIN FILHO, A.; PALAZZO, D.; BASSANEZI, R.B.; GODOY, C.V.; TORRES, G.A.M. Clorose variegada dos citros: uma escala diagramática para avaliação da severidade da doença. Fitopatologia Brasileira, v. 8, p. 174-180, 1993.

AMORIN, L.; BERGER, R. D.; BERGAMIN FILHO, A.; HAU, B.; WEBER, G.E.; BACCHI, L.M. A.; VALE, F.X.R.; SILVA, M.B. A simulation model to describe epidemics of rust of Phaseolus beans. II. Validation. Phytopatology, v. 85, p. 722$727,1995$.

AZEVEDO, O R.F.; SILVA FILHO, R.; RAMALHO SILVA, P.R.; CASSINO, P.C.R. Parasitismo de populações de Selenaspidus articulatus (Homoptera, Diaspididae), por (Hymenoptera, aphelinidae), em pomares cítricos na região citrícola do estado do Rio de Janeiro. In: CONGRESSO BRASILEIERO DE ENTOMOLOGIA, 8; ENCONTRO NACIONAL DE FITOSSANITARISTAS, Rio de Janeiro, 1998. Resumos. Rio de Janeiro, 9 a 14 de agosto de 1998. 710p.

BALACHOWSKY, A. Les cochenilles de France, d'Europe, du Nort de I'Afrique et du Bassin Mediterranen. Paris: Edit. 1951.

BARTRA, P.C.E. Biologia de Selenaspidus articulatus Morgan y sus principales controladores biológicos. Revista Peruana de Entomologia, v.17, n. 1, p.60-68, 1974. 
BARTRA P.C.E. Manual de crianza de algunos insectos benéficos a la agricultura peruana. Lima: Sociedad Entomológica del Perú, 1994. 56p.

BASSANEZI, R. B.; MARTINS, M.C.; GODOY, C.V.; AMORIN, L.; BERGAMIN FILHO, A. Efeito da antracnose na eficiência fotossintética do feijoeiro. Fitopatologia Brasileira, v.22, n.4, p.520-524, 1997.

BASTIAANS, L. Ratio between virtual and visdual lesion size as a measure to describe reduction in leaf photosynthesis of rice du a leaf blast. Phytopathology, v. 81, n. 6 , p.611-615, 1991.

BEARDSLEY JR. J. W.; GONZALES, R. H. The biology and ecology of armored scales. Annual Review of Entomology, 20, p.47-73, 1975.

BEINGOLEA, O.G. Notas sobre la biologia de Selenaspidus articulatus Morgan (Hom.: Diaspididae), "Queresa Redonda de los Cítricos". Revista Peruana de Entomologia, v.12, n. 1, p.119-129, 1969.

BERGMANN, E.C.; STRADIOTO, M.F.; BRISOLLA, A.D. Ocorrência de Selenaspidus articulatus (Morgan, 1889) em cultura de seringueira (Hevea brasiliensis Muell. Arg.) no município de Olímpia, Estado de São Paulo. Biológico, v.54, n. 1/6, p.27-28, 1988.

BLISS, C.I.; BROADBENT, B.M.; WATSON, S.A. The life histiry of the California Red scale Chrysomphalus aurantii Maskell: progress report. Journal of Economic Entomology, v.24, p. 1222-1229, 1931. 
CASSINO, P.C.R.; LIMA, E.R. de.; FERREIRA, I.T. Novo hospedeiro de Selenaspidus articulatus (Morgan, 1889) (Homoptera, Diaspididae) no Estado do Rio de Janeiro. In: CONGRESSO BRASILEIRO DE ENTOMOLOGIA, 10., Rio de Janeiro, 1986, Resumos. Rio de Janeiro: UFRRJ, 1986. p.388.

DEKLE, G.W. Arthropods of Florida and neighboring lands: Florida armored scale insects. Gainesville: Univ. Florida, Depto. Agric. Cons. Serv., 1976. v. 3, 345p.

DOMENICI, M.G.; BALDIN, E.L.L.; SCOPARIN, C.H.J. Preferência da fixação de Selenaspidus articulatus (Morgan, 1889) (Hemiptera, Diaspididae) na folha de citrus, em relação a sua localização. In: CONGRESSO BRASILEIRO DE ENTOMOLOGIA, 16.; ENCONTRO NACIONAL DE FITOSSANITARISTAS, 7. Salvador, 1997. Resumos. Salvador, 2 a 7 de março de 1997. 400p.

DZIEDZICK, A.; KARNKOWSKI, W. The contribution to knowledge of Selenaspidus articulatus (Morgan) (Homoptera, Coccinea (sic), Diaspididae). Acta Biologica Cracov. Series Zoologie, v. 32, p.39-43, 1990.

FERRAZ L. F. Infestação de cochonilha pardinha em sansão-do campo usado como cerca viva em pomares de laranja. Bragantia, v.56, n.2, p.289-290, 1997

FERRIS, G.F. Atlas of the sclae insects of North America. London: Stanford University Press, 1938. SII-265: Selenaspidus articularus (Morgan).

FLANDERS, S.E. Mass culture of california red scale and its golden chalcid parasites, Hilgardia, v. 21, n. 1, p.1-41, 1951. 
GARCIA, M.S. Biologia e potencial de controle de Ecdytolopha aurantiana (Lima, 1927) (Lepidoptera: Tortricidae), o bicho-furão-dos-citros, através de Trichogramma pretiosum Riley, 1879. Piracicaba, 1998. 118p. (Tese (Doutorado) Escola Superior de Agricultura “Luiz de Queiroz", Universidade de São Paulo.

GONÇALVES, C.R.; LIMA, A.F. Selenaspidus articulatus (Morgan), nova praga de plantas cítricas no Rio de Janeiro (Hom.:Diaspididae). In: CONGRESSO BRASILEIRO DE ENTOMOLOGIA, 6., Campinas, 1980. Resumos. Campinas: IB, 1980. p.64.

GONZALES, R.H. Biologia Y ecologia y control de la escama de San Jose en Chile. Publicación en Ciências Agrícolas, n. 9, 1981.

GONZÁLEZ-SICILIA DE JUAN, E. El cultivo de los agrios, Madrid: Ministério de Agricultura, Madrid, 1960. 806 p.

GOODWIN, P. H. Effect of common bacterial blight on leaf photosynthesis of bean. Canadian Journal of Plant Pathology, v. 14, p. 203-206, 1992.

GOUVEA DE, A ; DOS SANTOS, A V.; RODRIGUES, M. A DOS R.; CASSINO, P.C.R. Pragas associadas às plantas cítricas no município de Santa Inês, B.A. In: CONGRESSO BRASILEIRO DE ENTOMOLOGIA, 8; ENCONTRO NACIONAL DE FITOSSANITARISTAS, 8. Rio de Janeiro, 1998. Resumos. Rio de Janeiro, 9 a 14 de agosto de 1998. 710p.

GRAVENA, S. Manejo integrado de pragas de citros na atualidade. In: FERNANDES, O.A. Manejo integrado de pragas e nematóides. Jaboticabal: FUNEP, 1990. p.107-126. 
GRAVENA, S,; SILVA, J.L.; YAMAMOTO, P.T.; PAIVA, P.E.B. Manual do pragueiro, Jaboticabal. s.ed., 1995.40 p.

HADDAD, M.L. \& PARRA, J.R.P. Métodos para estimar os limites térmicos e a faixa ótima de desenvolvimento das diferentes fases do ciclo evolutivo dos insetos. EMBRAPA, Piracicaba: USP; FEALQ, 1984. 12p. (Série Agricultura e Desenvolvimento).

HERRERA ARANGUENA, J.M. Ciclos biológicos de las queresas de los cítricos en la Costa Central. Métodos para su control. Revista Peruana de Entomologia, v. 7, $\mathrm{n}$. 1, p.1-8, 1964.

HORSFALL, J.G.; BARRAT, R.W. An improved grading system for measuring plant diseases (abstr.). Phytothology, v. 35, p. 655, 1945.

JAMES, W.C. Assesment of plant diseases and losses. Annual Review of Phytopatology, v. 12, p. 27-48, 1974.

KITAJIMA, E.W.; LEITE, B. Curso introdutório de microscopia eletrônica de varredura. Núcleo de apoio à Pesquisa em Microscopia Eletrônica aplicada à pesquisa Agropecuária (NAP/MEPA), 1998. 38p.

LEÃO NETO, R. da R.; GRAVENA, S.; MORETTI, F.C.; TOZATT, G. Eficiência de inseticidas sobre a cochonilha Selenaspidus articulatus (Morgan) (Hom., Diaspididae) e efeito sobre inimigos naturais no pomar cítrico. In: CONGRESSO BRASILEIRO DE ENTOMOLOGIA, 10., Rio de Janeiro, 1986, Resumos. Rio de Janeiro: UFRRJ, 1986. p.321. 
LEITE, B.; PASCHOLATI, S.F. Hospedeiro: alterações fisiológicas induzidas por fitopatógenos. In: Bergamin Filho, A.; Kimati, H.; Amorin, L. Ed., Manual de fitopatología: principios e conceitos. 3.ed., São Paulo; Agronômica Ceres, 1995. v. 1, p. 939-416.

LEPAGE, H.S. Catálogo dos cocídeos do Brasil. Revista do Museu Paulista, t. 23, p.327-604, 1938.

LIMA de, A.F. Bioecologia de Orthezia praelonga Douglas, 1891 (Homoptera, Ortheziidae), Dissertação (Mestrado). Escola Superior de Agricultura "Luiz de Queiroz", Universidade de São Paulo. Piracicaba, 1981. 124p.

LONG, S.P.; HALLGREN, J.E. Measurement of $\mathrm{CO}_{2}$ assimilation by plants in the field and the laboratory. In: Hall, D.O.; Scurlock, J.M.O.; Bolharnordenkampf, H.R.; Leegood, R.C.; Long, S.P., Ed. Photosyntesis and production in a changing environment: A field and laboreatory manual. London: Chapman \& Hall, 1993. p.129-167.

LUCCHESI, R.; PAZINI, W.C.; BUSOLI, A.C.; CABRITA, J.R.M. Controle integrado da cochonilha parda Selenaspidus articulatus (Morgan, 1889) (Homop., Diaspididae) através de óleos minerais, inseticidas e fungos entomopatogênicos naturais. In: CONGRESSO BRASILEIRO DE ENTOMOLOGIA, 10., Rio de Janeiro, 1986, Resumos. Rio de Janeiro: UFRRJ, 1986. p.387.

MARICONI, A.M. Inseticidas e seu emprego no combate as pragas. São Paulo: Agronômica Ceres, 1963.607p.

MARIN, R. L. Biología y morfología de la "escama de San José" Quadraspidiatus perniciosus (Comst.) Revista Peruana de Entomologia ,v. 29, p. 81-87, 1987. 
MARIN, R. L.; CISNEROS, F. Biología y morfología de las especies de Pinaspis "piojo blanco" en cítricos de la costa central del Perú. Revista Peruana de Entomologia, v. 25, n. 1, p. $33-44,1982$.

McKENZIE, H.L. The armored scale insects of California. Berkeley: University of California Press, 1956. 357p. (Bulletin of the California, Insect. Surveys, 5).

MENEZES, E.B.; CASSINO, P.C.R. Ocorrência de Selenaspidus articulatus (Morgan, 1889) (Homoptera, Diaspididae) no Estado do Espírito Santo. In: CONGRESSO BRASILEIRO DE ENTOMOLOGIA, 9., Londrina, 1984, Resumos. Londrina: EMBRAPA, CNPSo, 1984. p.85.

NAKANO, O. Cochonilhas nos laranjais do Estado de São Paulo. Agronômico, n. 27, p.15-17, 1985.

NEVES, E.M. Exportação de frutas de mesa: sinais de mercado, Preços Agrícolas, v.11, n.130, p.24-28, 1997.

PARRA, J.R.P. Biologia comparada de Perileucoptera coffeella (Guérin-Méneville, 1842) (Lepidoptera, Lyonetiidae) visando ao seu zoneamento ecológico no Estado de São Paulo. Revista Brasileira de Entomologia, v.29, n.1, p.45-76, 1985.

PARRA, J. R. P. Técnicas de criação de Anagasta kuehniella, hospedeiro alternativo para produção de Trichogramma. In: Parra, J.R.P.; Zucchi, R.A. (Ed.). Trichogramma e o controle biológico aplicado. Piracicaba: FEALQ, 1997. Cap. 4, p.-121-151. 
$\checkmark$ PEREIRA, C.H.; SAMPAIO, M.V.; ASSUNÇÃO, E.D.; SILVA, M.J.P.R.; CASSINO, P.C.R. Flutuação populacional de Selenaspidus articulatus no Parque da Gleba e, Barra da Tijuca, R.J. In: CONGRESSO BRASIEIRO DE ENTOMOLOGIA, 16; ENCONTRO NACIONAL DE FITOSSANITARISTAS, 7. Salvador, 1997. Resumos. Salvador, 2 a 7 de março de 1997. 400p.

PEREIRA, C.H.; SILVA FILHO, R.; BRAGA, V. DE A ; MELLO, R. DE A ; CARVALHO, A DE F.; CASSINO, P.C.R. NOVAS hospedeiras para Selenaspidus articulatus (Morgan, 1889) (Hom., Diaspididae) no parque da "gleba e", barra da tijuca Rio de Janeiro. In: CONGRESSO BRASILEIERO DE ENTOMOLOGIA, 8; ENCONTRO NACIONAL DE FITOSSANITARISTAS, 8. Rio de Janeiro, 1998. Resumos, Rio de Janeiro, 9 a 14 de agosto de 1998. 710p.

PERRUSO, J.C.; CASSINO, P.C.R. Dados preliminares da flutuação populacional de Selenaspidus articulatus (Morgan, 1889) (Homoptera, Diaspididae) em Citrus sinensis (L.) Osbeck no Estado do Rio de Janeiro. In: CONGRESSO BRASILEIRO DE ENTOMOLOGIA, 14., Piracicaba, 1993, Resumos. Piracicaba: ESALQ/USP, 1993. p.598.

PINTO, A de S. et al. Efeito da poeira na distribuição da cochonilha Selenaspidus articulatus (Hemiptera, Diaspididae) e do ácaro Phyllocoptruta oleivora (Acari, Eryophiidae) em pomar de citros. In: SIMPÓSIO DE CONTROLE BIOLÓGICO, 4, 1994. GRAMADO, RS, Anais. Gramado: CPACT/EMBRAPA, 1994. p.304.

PINTO, A. de S. Flutuação populacional de Selenaspidus articulatus (Morgan) Hemiptera: Diaspididae) em citros e ocorrência de inimigos naturais no município de Taquaritinga - SP, Dissertação (Mestrado), Jaboticabal, 1995. 95p. Faculdade de Ciências Agrárias e Veterinárias, Universidade Estadual Júlio de Mesquita Filho. 
PRATES, H.S.; CABRITA, J.R.M.; PINTO, W.B.S. Selenaspidus articulatus, uma praga em potencial para a citricultura paulista. Campinas: CATI, 1985, 14p. (CATI - Comunicado Técnico).

PRATES, H.S. Eficiência de insecticidas no controle da cochonilha pardinha Selenaspidus articulatus (Morgan, 1889), em citrus. CATI, 1997. 11p.

PRATES, H.S.; DE NARDO, E.A B.; WATANABE, M.A. Ocorrência de inimigos naturais de Selenaspidus articulatus Morgan, 1889 (Hemiptera, Diaspididae) em pomares cítricos no estado de São Paulo. In: CONGRESSO BRASILEIRO DE ENTOMOLOGIA, 8; ENCONTRO NACIONAL DE FITOSSANITARISTAS, 8. Rio de Janeiro, 1998. Resumos, Rio de Janeiro, 9 a 14 de agosto de 1998. 710p.

QUAYLE, H.J. The red or orange scale. Agricultural Experimental Station Bulletin, n. 222, 1911. p. 150

RACCA FILHO, F.; CASSINO, P.C.R. Ocorrência de diaspidídeos em pomares citrícolas do Estado do Rio de Janeiro (Hom., Diaspididae). In: CONGRESSO BRASILEIRO DE ENTOMOLOGIA, 6., Campinas, 1980. Resumos. Campinas: Instituto Biológico, 1980. p.65.

RICE, R.E.; MORENO, D. S. Fliht of male califormia red scale. Annals of the Entomological Society of America, v. 63, n. 1, p. 91-96, 1970.

RODRIGUEZ, O.; VIÉGAS, F.; POMPEU JR. J.; AMARO, A. A. Citricultura brasileira. 2. ed. Campinas: Fundação Cargill, 1991, 492 p.

ROSEN, D.; GERSON, U. Field studies of Chilocorus bipustulatus (L.) on citrus in Israel. Annales des Epiphythies, n.16, p.71-76, 1985. 
SALISBURY, F.B.; ROSS, C. W. Plant physiology. Belmont: Wadsworth, 1992. $682 \mathrm{p}$.

SANTANA, A.E.; PINTO, R.A.; YAMAMOTO, P.T.; GRAVENA, S. Parasitismo e ocorrência natural da cochonilha Selenaspidus articulatus (Morgan) (Hemiptera: Diaspididae) em citros. In: SIMPÓSIO DE CONTROLE BIOLÓGICO, 4., Gramado, 1994, Resumos. Pelotas: EMBRAPA, CPACT, 1994. p.250.

SGRILLO, R.B. A distribuição de weibull como modelo de sobrevivência de insetos, Ecossistema, v. 7, p. 9-13, 1982.

SILVA FILHO, R.; PEREIRA, C.H.; AZEVEDO, O R.F.; MELLO, R. DE A ; CARVALHO, A DE F.; CASSINO, P.C. Monitoramento de Selenaspidus articulatus (Morgan, 1889) (Hom., Diaspididae) em Sizygium cuminii (Jamelão) no parque da "gleba", barra de Tijuca, R.J. In: CONGRESSO BRASILEIERO DE ENTOMOLOGIA, 8.; ENCONTRO NACIONAL DE FITOSSANITARISTAS, 8. Rio de Janeiro, 1998. Resumos, Rio de Janeiro, 9 a 14 de agosto de 1998. 710p.

SILVEIRA NETO, S,; NAKANO, O.; BARBIN, D.; VILLA NOVA, N. A. Manual de ecologia de insetos. São Paulo: Agronômica Ceres, 1976. 419 p.

SURÍS, M. Influencia del patrón en la presencia de Selenaspidus articulatus (Coccoidea: Diaspididae) en cítricos. Agrotecnica Cuba, v. 17, n. 2, p.27-30, 1985.

SURÍS, M.; VARONA, I. Distribución espacial de Selenaspidus articualtus (Coccoidea: Diaspididae) en una plantación de naranjo Valencia. Revista Proteção Vegetal, v.3, n. 1, p.38-44, 1988. 
TASHIRO, H. \& BEAVERS, J.B. Growth and development of the Califomia red scale, Aonidiella aurantii. Annals of the Entomological Society of American, v.61, n.4, p. 1009-1014, 1968.

WASHBURN, J. O; FRANKIE, G. W. Biological studies of iceplant scales, Pulvinariella mesembryanthemi and Pulvinaria delottoi (Homoptera: Coccidae), in Califormia. Hilgardia, v. 53, n. 2, p. 1-27, 1985.

WATANABE, M.A.; YOSHI, C. Parasitismo em cochonilha pardinha Selenaspidus articulatus (Hemiptera-Homoptera, Diaspididae) por Aphytis sp. (Hymenoptera, Aphelinidae). Revista Agricultura, v. 67, n. 1, p.63-65, 1992.

WATANABE, M.A.; YOSHII, C.; SILOTO, R.C. Parasitismo em cochonilha Selenaspidus articulatus (Homoptera, Diaspididae) (Morgan, 1889) em citros nas regiões de Jaguariúna e Limeira, SP. Revista Agricultura, v. 69, n. 2, p. 193-200, 1994.

WATANABE, M. A. Ocorrência de cochonilha pardinha Selenaspidus articulatus e seus parasitóides nativos na região de Limeira-SP. In: CONGRESSO BRASILEIRO DE ENTOMOLOGIA, 16.; ENCONTRO NACIONAL DE FITOSSANITARISTAS, 7. Salvador, 1997. Resumos. Salvador, 2 a 7 de março de 1997. 400p.

WILLE, J.E. Entomologia Agricola del Peru. Lima: Ministerio de Agricultura, 1952.

WILliams, D.J.; WATSON, G.W. The scale insects of the tropical South Pacific Region. Part 1. The armoured sacales (Diaspididae). Wallingford: $C A B$ Internacional, $1988.290 \mathrm{p}$. 
XAVIER, A.L.Q.; FREITAS DE, S.; SCOPARIN, C.H.J. Avaliação da capacidade de predação de Chrysoperla externa (Hagen, 1961) (Neuroptera, Chrysopidae) sobre a cochonilha Selenaspidus articulatus (Morgan, 1889) (Hemiptera, diaspididae). In: CONGRESSO BRASILEIRO DE ENTOMOLOGIA, 16; ENCONTRO NACIONAL DE FITOSSANITARISTAS, 7. Salvador, 1997. Resumos. Salvador, 2 a 7 de março de 1997. 400p.

YUST, H.R. Rufous scale on robusta coffee in Equador. Journal of Economic Entomology, v. 56, n. 3, p.404, 1958. 